\title{
Republic of Moldova: Selected Issues
}

This Selected Issues paper on the Republic of Moldova was prepared by a staff team of the International Monetary Fund as background documentation for the periodic consultation with the member country. It is based on the information available at the time it was completed on September 17, 2012. The views expressed in this document are those of the staff team and do not necessarily reflect the views of the government of the Republic of Moldova or the Executive Board of the IMF.

The policy of publication of staff reports and other documents by the IMF allows for the deletion of market-sensitive information.

\author{
Copies of this report are available to the public from \\ International Monetary Fund • Publication Services \\ $70019^{\text {th }}$ Street, N.W. • Washington, D.C. 20431 \\ Telephone: (202) 623-7430 • Telefax: (202) 623-7201 \\ E-mail: publications@imf.org Internet: http://www.imf.org
}

\section{International Monetary Fund Washington, D.C.}




\section{INTERNATIONAL MONETARY FUND}

\section{REPUBLIC OF MOLDOVA}

\section{Selected Issues}

Prepared by Gabriel Srour, Michael Gorbanyov (all EUR), Tidiane Kinda (FAD) and Svitlana Maslova (SPR)

Approved by Aasim M. Husain

September 17, 2012

Contents

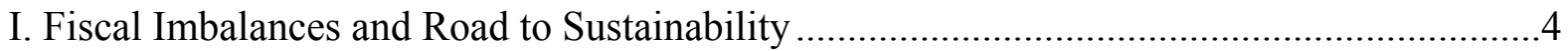

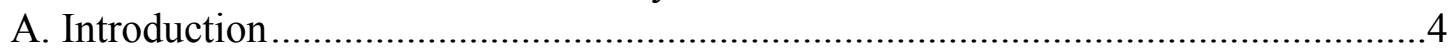

B. Fiscal Imbalances Entering the Crisis ..................................................................

C. The Adjustment So Far ..................................................................................

D. Tackling Challenges to Maintain Fiscal Sustainability …………………................

E. Pension Reform .........................................................................................

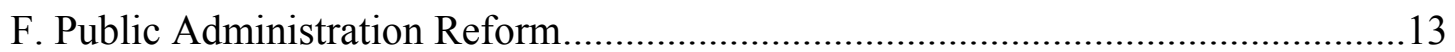

G. Further Education Reform ……………………..........................................18

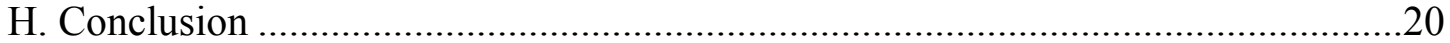

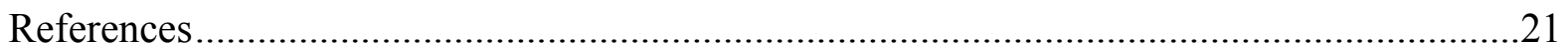

II. FDI Potential, Performance, and External Competitiveness...............................................22

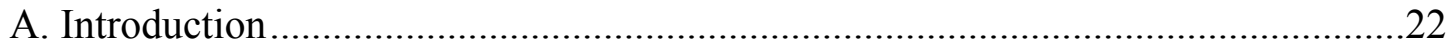

B. Improvements in Competitiveness and Ease of Doing Business .............................25

C. Growth Potential and Engines of Growth ............................................................2

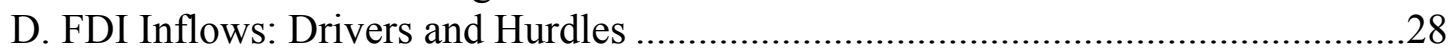

E. External Price Competitiveness.................................................................................

F. CGER-type Exchange Rate Assessment ……………………………..................38

G. Conclusions and Policy Recommendations ............................................................40

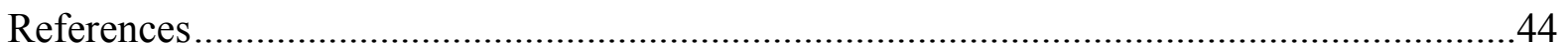

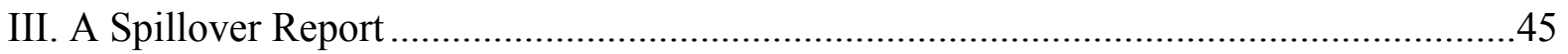

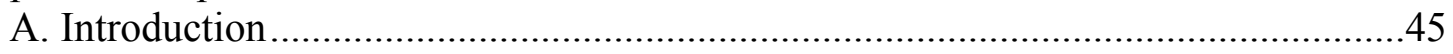

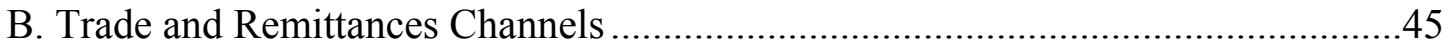

C. Capital and Financial Spillovers …………………...............................................49

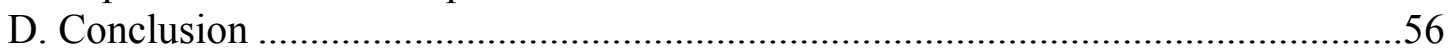


Tables

I.1. Headline and Structural Fiscal Balances of the General Government, 2001-12 ..............5

I.2. Pension Contributions and Expenditures.................................................................... 10

I.3. Moldova and Selected Countries: Replacement Rates ...................................................10

I.4. Moldova and Selected Countries, Pensionable Ages, 2010-30 ....................................11

I.5. Pension Reform Scenarios Simulated with the Pension Model .......................................12

I.6. Moldova and Selected Countries: Public Sector Employment, 2000-10........................14

I.7. Moldova and Selected Countries: Public Employment by Sector, 2010.........................16

I.8. Moldova and Selected Countries: Change in the Number of

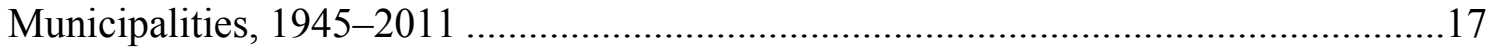

I.9. Local Governments in Moldova by Number of Inhabitants, 2008...............................17

I.10. Educational Expenditure as a Percent of Total Educational Expenditure......................19

I.11. Moldova and Selected Countries: Total Public Expenditure on Educational Institutions

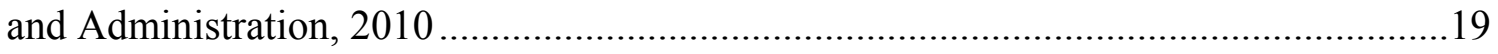

II.1. Position in International Rankings .....................................................................25

II.2. Moldova and Selected Countries: Positions in "Doing Business" Survey, 2011 ............26

II.3. GDP Growth and Contributions, 2001-17 ..........................................................27

II.4. Accumulated FDI in Equity Capital of the Companies in Sectors Producing Tradables

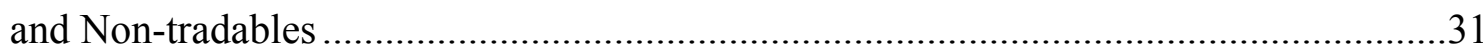

II.5. Fixed Investments of Foreign and Joint Companies, 2001-11 .....................................32

II.6. Value Added Produced by Foreign and Joint Companies in Selected Industries, 2011 ..32

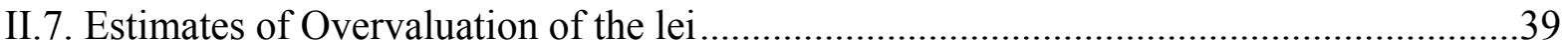

II.8. Estimation of the Trade Balance Elasticity for Moldova............................................39

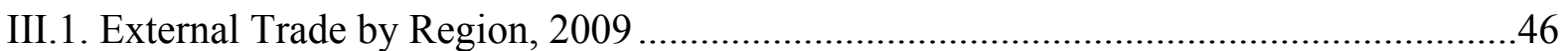

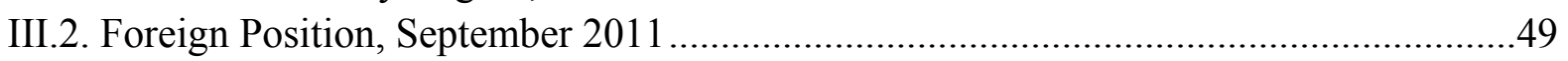

III.3. Financial Soundness Indicators, September 2011 ....................................................50

III.4. Banking System Foreign Position, September 2011 ................................................51

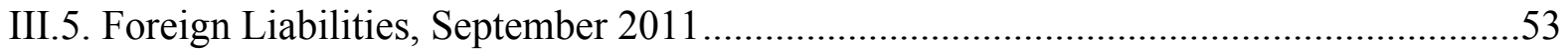

Figures

I.1. General Government Fiscal Balance, 2001-12 ...........................................................5

I.2. General Government Current Expenditures, 2001-12 ...................................................5

I.3. First Pillar Pension Fiscal Balance ............................................................................. 13

I.4. Average Old-Age Pension Rate Relative to Average Gross Wage .................................13

I.5. Moldova and Selected Countries: Average Size of Municipalities, 2010/2011 ..............15

I.6. Moldova and Selected Countries: General Government Expenditure on

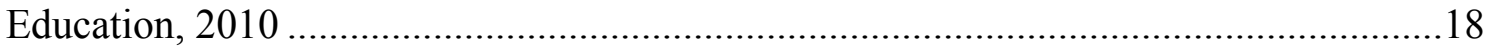

II.1. Economic Developments, 1995-2011 .......................................................................23

II.2. GDP Composition and Investments, 1995-2011 ................................................24 
II.3. Global Competitiveness Index: The Most Problematic Factors for Doing Business in

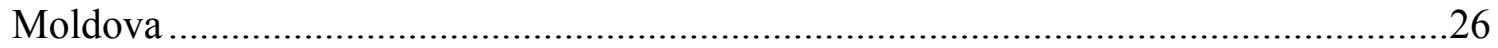

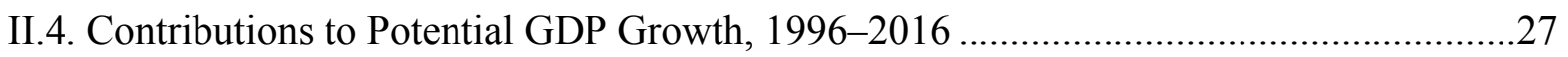

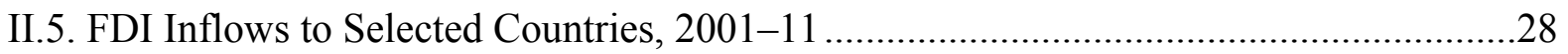

II.6. FDI to GDP Ratio and GDP per Capita in Selected Countries, 2010 ….........................22

II.7. FDI Performance and Potential Indices for Selected Countries, 2008-10......................29

II.8. Moldova FDI Stock: Equity Capital by Main Source Countries, 2008 and 2011 ............31

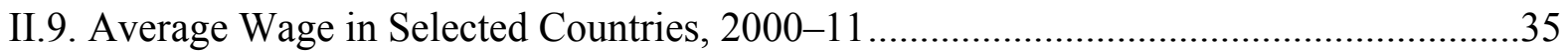

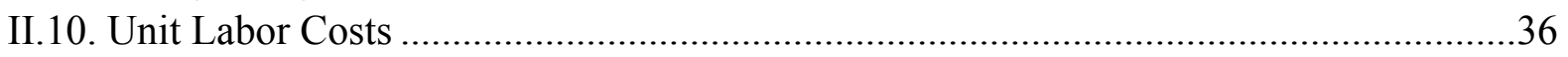

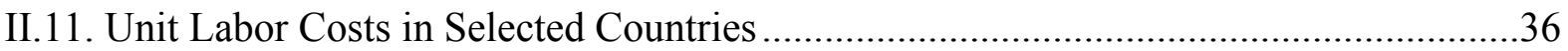

II.12. Real Effective Exchange Rates: Country Comparison .................................................37

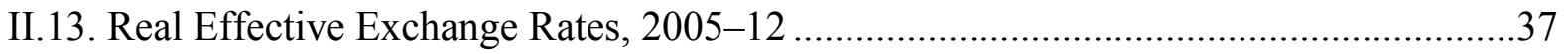

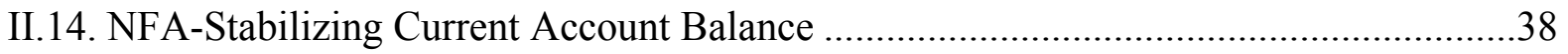

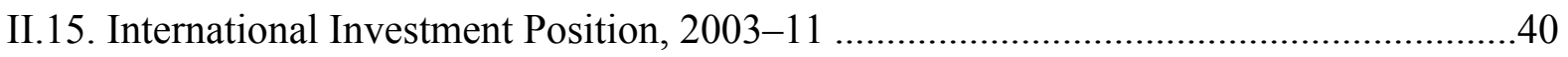

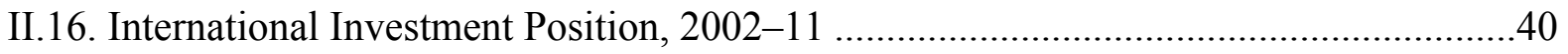

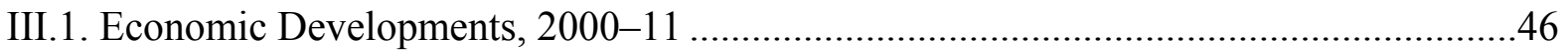

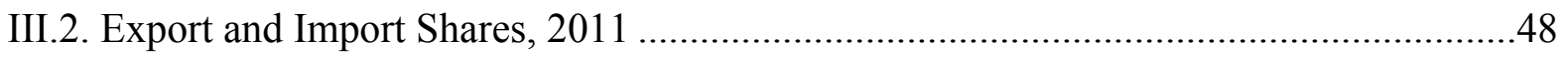

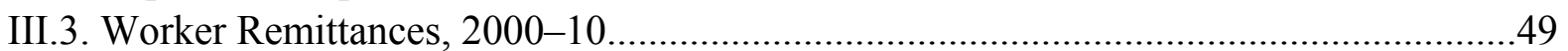

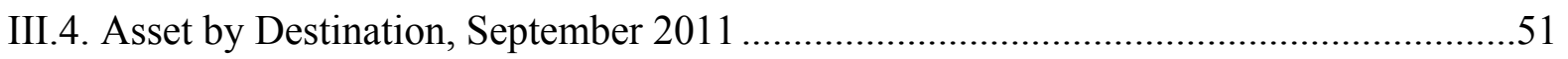

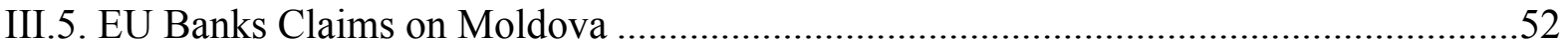

III.6. Banks Foreign Liabilities by Origin, September 2011 ...............................................53

III.7. Current Account Deficit and Sources of Financing....................................................54

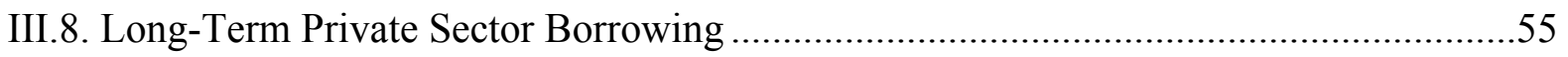

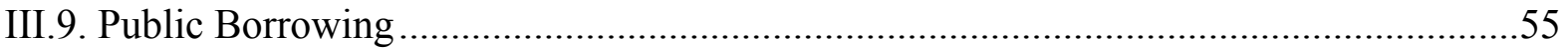

Boxes

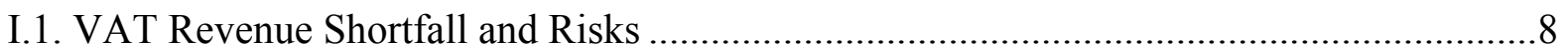

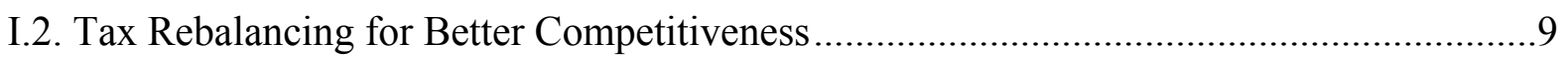

II.1. The Experience with Structural Reforms in Georgia.....................................................34

Appendixes

II. I. Methodology of Calculating FDI Performance and Potential Indices.............................42

III. I. Econometric Analysis of Trade and Remittances Flows..............................................58 


\section{FisCAL IMBALANCES AND ROAD TO SUSTAINABILITY ${ }^{1}$}

\section{A. Introduction}

1. Reaching and sustaining fiscal sustainability is a key priority in Moldova. While fiscal adjustment in 2010-11 has significantly reduced the large post-crisis deficit, the budget remains heavily dependent on exceptional external assistance and vulnerable to macroeconomic shocks. The ongoing adjustment in 2012 is expected to lead to a stronger fiscal position, reducing the budget's dependency on exceptional foreign financing and increasing its resilience to shocks.

\section{Progress has been made toward fiscal sustainability but challenges remain.}

Staying the course on fiscal adjustment is expected to bring the budget back to fiscal sustainability by end-2012. The main challenge, however, will be to maintain it in face of increasing pressures, stemming mainly from the declining external assistance and the crucial need to enhance infrastructure and service social insurance commitments. With the recent comprehensive tax policy reform, further expenditure rationalization is the key element. The rationalization measures however need to be embedded in structural reforms to have longlasting impacts. Structural reforms are also needed because of the still high structural fiscal balance that is expected by end-2012. ${ }^{2}$

3. The structure of the paper is as follows. Section II analyzes the main fiscal imbalances before the crisis as well as the impact of the crisis. Section III summarizes recent achievements in tax and expenditures policies on the road to fiscal sustainability. Section IV describes the remaining challenges to maintain fiscal sustainability. This section focuses on three critical expenditure rationalization areas that are key for medium to long-term fiscal and social sustainability. In this regard, the first part of Section IV analyzes the pension reform, specifically how to limit the drop of pension benefits without undermining its fiscal sustainability. The second part of the section investigates a reform of the local public administration to reduce costs and improve the efficiency of public service delivery. The last part of the section analyzes the second stage of the education reform, aiming- as the first stage - at generating fiscal savings and improving quality.

\footnotetext{
${ }^{1}$ Prepared by Tidiane Kinda.

${ }^{2}$ The structural fiscal balance is the cyclically adjusted balance corrected for one-off factors. It captures budgetary changes expected to persist over the medium-term.
} 


\section{B. Fiscal Imbalances Entering the Crisis}

4. Moldova entered the crisis with a structurally weak fiscal position. The structural fiscal deficit deteriorated after the mid-2000s. From zero in 2001, the structural budget deficit excluding grants increased to 5.1 percent of potential GDP in 2008 as a result of large tax cuts and steady expenditure increases (Figure 1 and table 1). The CIT rate was lowered from 28 percent in 2001 to 15 percent in 2006 and zero in 2008, along with numerous tax exemptions. Reduced rates for a number of products were also introduced in the VAT system and the top PIT rate was reduced to 18 percent. Current budgetary spending steadily increased from 26 percent of GDP in 2001 to 341/2 percent of GDP in 2008 (Figure 2).

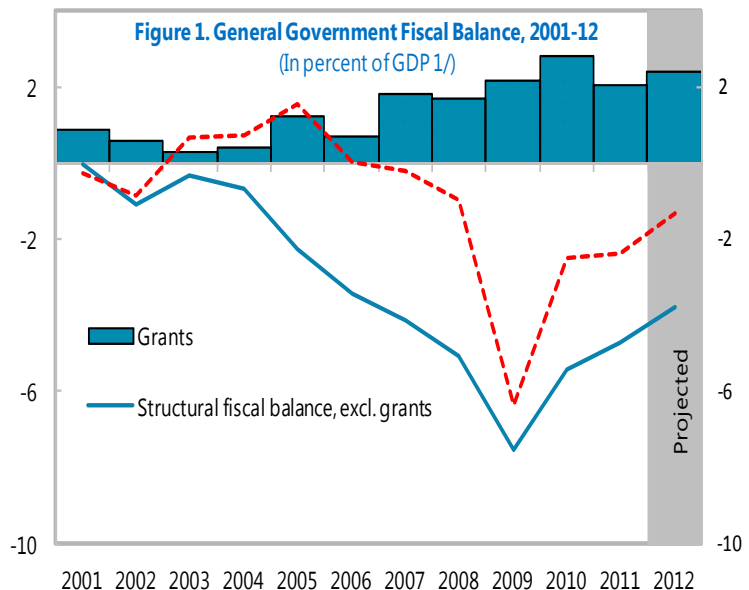

200120022003200420052006200720082009201020112012

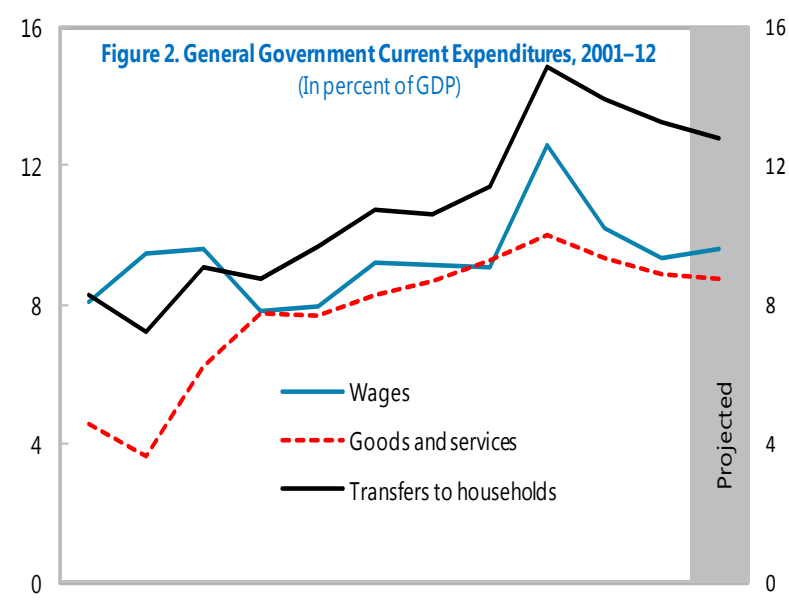

200120022003200420052006200720082009201020112012

Sources: Moldovan authorities; and IMF staff estimates.

1 / Structural fiscal balance is expressed in percent of potential GDP.

Table 1. Headline and Structural Fiscal Balances of the General Government, 2001-12

(Percent of GDP, unless otherwise indicated)

\begin{tabular}{|c|c|c|c|c|c|c|c|c|c|c|c|c|}
\hline & 2001 & 2002 & 2003 & 2004 & 2005 & 2006 & 2007 & 2008 & 2009 & 2010 & 2011 & $\begin{array}{l}2012 \\
\text { Proj. }\end{array}$ \\
\hline Headline revenue and grants & 29.2 & 29.6 & 34.0 & 35.4 & 38.6 & 39.9 & 41.7 & 40.6 & 38.9 & 38.3 & 36.7 & 38.1 \\
\hline Domestic revenue & 28.3 & 29.0 & 33.7 & 35.0 & 37.3 & 39.2 & 39.9 & 38.9 & 36.8 & 35.5 & 34.6 & 35.7 \\
\hline Tax revenue & 24.4 & 25.8 & 27.5 & 29.8 & 31.6 & 33.3 & 34.0 & 33.4 & 32.0 & 31.0 & 30.8 & 31.7 \\
\hline Non tax revenue & 3.9 & 3.1 & 6.2 & 5.2 & 5.8 & 5.9 & 5.9 & 5.4 & 4.8 & 4.6 & 3.8 & 4.0 \\
\hline Grants & 0.9 & 0.6 & 0.3 & 0.4 & 1.2 & 0.7 & 1.8 & 1.7 & 2.1 & 2.8 & 2.1 & 2.4 \\
\hline Structural revenue & 30.6 & 29.9 & 33.8 & 33.9 & 35.2 & 37.0 & 38.5 & 36.8 & 38.0 & 35.9 & 34.3 & 35.6 \\
\hline Automatic stabilizers & -2.3 & -0.9 & -0.1 & 1.0 & 2.1 & 2.2 & 1.4 & 2.1 & -1.3 & -0.3 & 0.3 & -0.2 \\
\hline One-off factors & 1.2 & 0.6 & 0.8 & 0.0 & 0.5 & 0.4 & 0.6 & 0.0 & 0.6 & 0.5 & 0.0 & 0.4 \\
\hline Expenditure and net lending & 29.4 & 30.4 & 33.3 & 34.6 & 37.0 & 39.8 & 42.0 & 41.6 & 45.2 & 40.8 & 39.1 & 39.4 \\
\hline Current & 26.0 & 25.8 & 28.9 & 29.8 & 30.9 & 32.2 & 34.6 & 34.5 & 40.3 & 36.1 & 34.0 & 33.6 \\
\hline Capital & 3.5 & 5.0 & 4.6 & 5.0 & 6.2 & 7.8 & 7.5 & 7.0 & 5.0 & 4.8 & 5.2 & 6.0 \\
\hline Headline fiscal balance (incl. grants) & -0.3 & -0.8 & 0.7 & 0.7 & 1.5 & 0.0 & -0.2 & -1.0 & -6.3 & -2.5 & -2.4 & -1.3 \\
\hline Structural fiscal balance (incl. grants) $1 /$ & 2.0 & 0.1 & 0.7 & -0.3 & -0.5 & -2.2 & -2.3 & -3.3 & -5.5 & -2.6 & -2.7 & -1.4 \\
\hline Structural fiscal balance (excl. grants) 1/ & 1.2 & -0.5 & 0.4 & -0.7 & -1.8 & -2.9 & -4.2 & -5.1 & -7.5 & -5.4 & -4.8 & -3.8 \\
\hline \multicolumn{13}{|l|}{ Memorandum: } \\
\hline Output gap & -7.5 & -3.1 & -0.2 & 3.3 & 6.5 & 6.5 & 3.9 & 6.2 & -3.6 & -1.0 & 0.9 & -0.7 \\
\hline
\end{tabular}

Source: IMF staff estimates.

1 Structural fiscal balances are expressed in percent of potential GDP. 
5. The crisis exposed the structural fiscal imbalances and exacerbated an already deteriorating fiscal position. The demand boom in 2006-08 that fuelled cyclically strong revenue and temporarily masked the weak structural fiscal position was reversed with the 2009 economic recession, exposing substantial fiscal imbalances. Revenue declined substantially, while expenditure kept rising, fueled by election-motivated hikes in wages and pensions. The headline deficit moved from 1 percent of GDP in 2008 to 6.3 percent of GDP in 2009, while the structural deficit deteriorated further, to 7.5 percent of GDP. These imbalances required sizeable adjustments and extraordinary financial assistance from the international community.

\section{The Adjustment So Far}

6. The government embarked on an ambitious fiscal adjustment in 2010. The government adopted a set of fiscal consolidation measures under the three-year Fund-supported program approved in January 2010. The program's objective is to restore fiscal sustainability, operationalized by a return to the pre- 2008 structural fiscal balance. The fiscal adjustment measures combine a comprehensive tax policy reform to promote investment and raise revenues as well as a reform-based rationalization of current expenditures while expanding public investments and targeted social spending. ${ }^{3}$

\section{Successful expenditure restraint in $\mathbf{2 0 1 0}$ was followed by reform-based-} rationalization in 2011 to lock in the gains from consolidation. Overall, current expenditure declines by 6.3 percent of GDP between 2009 and 2011. Wage and employment restraint reduced the wage bill by 2.2 percentage points of GDP, while various rationalization measures substantially reduced other current expenditures by 4.1 percentage points of GDP over this period. As a result, the structural deficit dropped from 7.5 percent of GDP in 2009 to 4.8 percent of potential GDP in 2011 (Table 1). To lock in the gains from the consolidation and prevent deterioration in the quality of public services, structural expenditure reforms have been implemented since 2011. These reforms include phasing out early retirement privileges, moving toward a more incentive compatible sick-leave benefits system, expanding the mean-tested Ajutor Social along with scaling down the nominative compensation scheme, and reforming the oversized education sector.

\section{A comprehensive tax policy reform has been implemented in 2012. The} government adopted a comprehensive tax policy package to stimulate investment and sustain the consolidation effort. The tax policy package includes the extension of VAT cash refunds for investment good purchases to the entire country, the re-introduction of the CIT with a single rate of 12 percent along with a sizeable reduction of tax exemptions and accelerated amortization of fixed assets, and gradual alignment of excise rates with EU minimum requirements. These reforms are expected to yield a permanent net revenue gain of

\footnotetext{
${ }^{3}$ See Qehaja (2012) for a summary of the main tax policy changes in Moldova.
} 
0.8 percent of GDP after accounting for the sizable loss associated with the expansion of the VAT refunds.

9. The expenditure and tax reforms are expected to lead to a sustainable fiscal position by end-2012. After three years of adjustment and structural reforms, the structural deficit (excluding grants) is projected to reverse its post-2007 deterioration by falling to 3.8 percent of potential GDP by end-2012, which translates into a headline budget deficit of $1 \frac{1}{4}$ percent of GDP. This level is deemed sustainable as it can be financed without exceptional foreign assistance. While fiscal sustainability is expected to be reached by end-2012, maintaining it will be a challenge.

\section{Tackling Challenges to Maintain Fiscal Sustainability}

10. Fiscal sustainability is fragile and remains vulnerable to even moderate shocks. The projected structural budget deficit of 3.8 percent of potential GDP in 2012 remains high by international standards, and challenges to maintain even the current level of revenue and expenditure are emerging. On the revenue side, VAT, the main source of tax revenue, has been lagging the dynamics in import and retail sales since early 2011 (Box 1). The steady projected decline of developmental assistance, particularly grants, over the medium term will need to be offset. Genuine economic trends (e.g., labor force and employment dynamics) as well as tax evasion are eroding the payroll taxes and pressures from special interests are putting CIT and PIT revenue at risk. On the expenditure side, the need to increase public investment and expand targeted social assistance requires additional fiscal space.

\section{Further reform-based rationalization of current spending should remain the} priority. After the comprehensive tax policy reform in 2012, a growth-friendly strategy to tackle the challenge of maintaining fiscal sustainability should rely mainly on further reformbased rationalization of current spending, given their still high level in Moldova (Figure 2), particularly when compared to peer countries (Karam, 2010). The main challenges on the current expenditure front include the pension reform, the local public administration reform, and the extension of the ongoing education reform to the whole sector.

\section{While there is room for further revenue enhancements, they could represent a} secondary pillar of the medium-term fiscal strategy. In line with the EU integration agenda, excise rates need to increase gradually over the medium-term to reach the EU requirements. There is also room to raise additional real estate taxes through adequate property valuation and tax rates adjustments. Given the number of reduced and zero rates, however, closing VAT loopholes has the highest revenue enhancement potential.

Strengthening tax administration, particularly for VAT and payroll taxes, is a key challenge to prevent a decline in collection due to higher evasion. Some changes in the tax structure could be tailored to improve the economy's competitiveness (Box 2). 


\section{Box I.1. VAT Revenue Shortfall and Risks}

VAT revenue has been lagging behind economic activity since early 2011 . VAT revenue has continued to underperform relative to growth in retail sales and imports (Chart). This is mainly explained by the sharp increase in the proportion of reduced rate and zero-rated supplies to total output between 2009 and 2011.

\section{This development calls for further improvement of VAT administration and a broadening of} the VAT base. To preserve the contribution of VAT as the main source of tax revenue, particularly with the expansion of VAT cash refunds for purchases of investment goods, VAT compliance and control need to be strengthened, with a particular attention to high-risk taxpayers. Efforts to strengthen tax compliance have reduced domestic VAT shortfall but the gap between potential VAT revenue and actual collection is nevertheless widening because of the sharply rising volume of reduced-rate and zero- rated supplies, a sign of evasion. This calls for further improvement in VAT administration, particularly automatic cross-checking of VAT returns (from the State Tax Inspectorate) against information on import VAT and zero-rated exports (from customs) to identify potential anomalies. Broadening the VAT tax base, by reducing the number of reduced and zero rates on non-standard goods (electricity, natural gas, sugar, automobiles) will also unleash the potential of the VAT to raise additional fiscal revenue.

\begin{tabular}{|c|c|c|c|c|}
\hline \multicolumn{5}{|c|}{$\begin{array}{c}\text { Determinants of Total Real VAT } \\
\text { (net of VAT Refunds) }\end{array}$} \\
\hline & \multicolumn{4}{|c|}{$\log (V A T)$} \\
\hline & $T$ & II & III & IV \\
\hline \multirow[t]{2}{*}{$\overline{L o g}(\operatorname{Import})$} & 0.369 & 0.306 & 0.295 & 0.371 \\
\hline & $(7.16)^{* * *}$ & $(5.17)^{* * *}$ & $(4.71)^{* * *}$ & $(7.24)^{\star * \star}$ \\
\hline \multirow[t]{2}{*}{$\log (R$. sales $)$} & 0.242 & 0.477 & 0.592 & 0.227 \\
\hline & $(2.46)^{* *}$ & $(2.83)^{* * *}$ & $(3.01)^{* * *}$ & $(1.32)$ \\
\hline \multirow[t]{2}{*}{ Trend } & & -0.002 & -0.002 & \\
\hline & & $(-1.49)$ & $(-1.61)$ & \\
\hline \multirow[t]{2}{*}{ Log(Gov. exp.) } & & & -0.106 & \\
\hline & & & $(-1.24)$ & \\
\hline \multirow[t]{2}{*}{ Red. rates } & & & & 0.001 \\
\hline & & & & $(0.10)$ \\
\hline Monthly dummy & Yes & Yes & Yes & Yes \\
\hline \multirow[t]{2}{*}{ Constant } & 2.575 & 2.086 & 2.506 & 2.62 \\
\hline & $(4.06)^{\star * *}$ & $(2.99)^{\star * *}$ & $(2.78)^{* * *}$ & $(3.16)^{* * *}$ \\
\hline R2 & 0.87 & 0.88 & 0.88 & 0.87 \\
\hline Observation & 51 & 51 & 51 & 51 \\
\hline
\end{tabular}

\section{VAT Revenue Collection Shortfall: Model III (in constant millions of lei)}

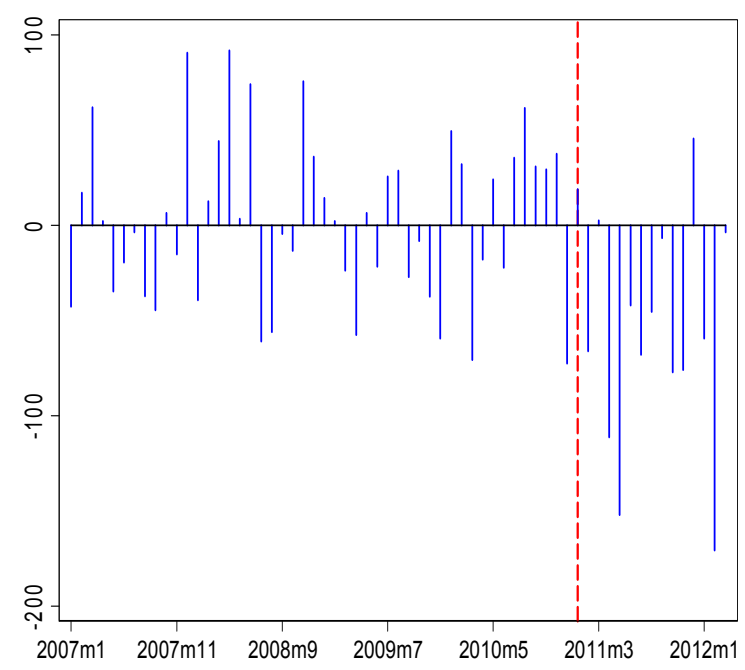

Import is the value of imports in constant lei. $R$. sales and I. prod are respectively the retail and industrial production indexes in real terms. Trend represents the time trend and Gov. exp captures general government expenditures in constant lei. Red. rates represents the number of VAT reduced rates. 


\section{Box I.2. Tax Rebalancing for Better Competitiveness}

The current level of social and health contributions creates a large tax wedge. The combined rate of social security and health contributions amount to a total tax burden of 36 percent, associated with underreporting of wages and salaries. The wage bill growth in 2011 fell short of nominal GDP growth by 7 percentage points, leading to an underperformance of payroll taxes.

During the crisis, many countries have reduced social contributions paid by the employers to improve their competitiveness. The OECD Employment Outlook 2010 reports that eight countries reduced their social contributions rates to lower their labor costs. To offset the subsequent revenue lost, cut in social contributions can be combined with higher VAT, often referred to as "fiscal devaluation" (Ruud and Keen, 2012).

Given its high tax wedge and number of reduced and zero VAT rates, such a tax shift could be considered in Moldova. In their attempt to reduce the tax burden on businesses to improve compliance, the authorities could offset the revenue loss of lower social contributions by implementing a VAT reform that includes (i) an increase of the VAT rate on sugar from 8 percent to the normal 20 percent VAT rate; (ii) an increase of the reduced rate on natural gas from 6 to 10 percent; (iii) an increase of the reduced rates on other goods (food products, medical equipment, and pharmaceuticals) from 8 to 10 percent; and (iv) an introduction of a 10 percent VAT rate on electricity and automobiles. Assuming that the reduction of social contributions is fully passed on to producer prices, this tax shift could reduce firms' incentive to remain in the informal sector, improve compliance, and foster competitiveness in the short-run. Simple simulations suggest that the above mentioned VAT reform would increase VAT revenue by about 1.1 percent of GDP. This higher VAT revenue would allow a reduction of social contributions rate by 4 percentage points, from 29 to 25 percent, without endangering fiscal revenue. Alternatively, part of the revenue gain from the VAT reform could be used to reduce social contributions rate by 3 percentage points and the remaining (0.3 percent of GDP) saved. 


\section{E. Pension Reform}

13. A sharp increase in pension expenditures in 2009 has raised concerns about the medium-term sustainability of the pension system. A 20 percent increase of pension expenditures has led to a sharp increase of the pension system deficit in 2009, questioning its medium-term sustainability. While pension expenditures decreased in the following years as a share of GDP, declining contributions continue to threaten the fiscal balance of the system (Table 2).

Table 2. Moldova: Pension Contributions and Expenditures 1/

\begin{tabular}{lccccc}
\multicolumn{7}{c}{ (Percent of GDP) } \\
\hline Contributions & 2007 & 2008 & 2009 & 2010 & 2011 \\
Expenditures & 7.2 & 7.2 & 7.8 & 7.0 & 6.7 \\
Overall Balance & 7.8 & 7.9 & 9.9 & 8.7 & 8.3 \\
\hline
\end{tabular}

Source: Government of Moldova, Ministry of Labor, Social Protection, and Family. 1/ First pillar pension.

14. The current pension scheme is moving towards a fiscally sustainable but socially unsustainable system over the medium and long-term. The 1998 pension reform linked pensions to lifetime contributions, established a minimum contribution period of 30 years for full benefits, gradually raised retirement ages from 60 to 62 years for men and 55 to 57 years for women, and eliminated some special pension schemes. However, the abrupt halt of the reform in 2003, coupled with various ad-hoc patches, set the gross replacement rate on a path of gradual reduction, from 35 percent in 1999 to less than 20 percent by $2030 .{ }^{4}$ This pronounced and sustained decline of the replacement rate will keep pension expenditures under control but seriously undermine key objectives of pension system such as income replacement and poverty reduction (IMF, 2011). Compared to countries in the region, the replacement rate in Moldova is low and projected to decline further in the long-term (Table 3).

Table 3. Moldova and Selected Countries: Replacement Rates.

\begin{tabular}{lll}
\hline & 2010 & 2030 \\
\hline Poland & 62.7 & 33.6 \\
Estonia & 47.0 & 34.3 \\
Russia & 42.9 & 42.9 \\
Bulgaria & 41.2 & 25.9 \\
Ukraine & 40.8 & 40.8 \\
Lithuania & 40.4 & 32.2 \\
Hungary & 39.9 & 34.2 \\
Romania & 38.2 & 36.7 \\
Latvia & 36.4 & 33.2 \\
Moldova & $\mathbf{2 8 . 2}$ & $\mathbf{1 8 . 1}$ \\
Average 1/ & 43.3 & 34.9 \\
\hline
\end{tabular}

Source: IMF, 2011.

1/ Excluding Moldova.

\section{Statutory retirement age is relatively low in Moldova, particularly for women.}

The current retirement age of 62 years for men in Moldova is below the average of advanced

\footnotetext{
${ }^{4}$ The gross replacement rate is the average old age pension divided by the average gross wage.
} 
economies (IMF, 2011) but not far from men's life expectancy at retirement. Women's retirement age is, however, below the average of comparable countries, and this gap is expected to increase over time (Table 4). At retirement, women are expected to live and draw a pension for $201 / 2$ years compared to only 12 years for men. Moreover, the lower retirement age for women results in a lower pension and raises old-age poverty.

Table 4. Moldova and Selected Countries:

Pensionable Ages, 2010-30 1/

\begin{tabular}{lcccc}
\hline & \multicolumn{2}{c}{ Men } & \multicolumn{2}{c}{ Women } \\
\cline { 2 - 5 } & 2010 & 2030 & 2010 & 2030 \\
\hline Bulgaria & 63 & 63 & 60 & 60 \\
Estonia & 63 & 65 & 61 & 65 \\
Hungary & 60 & 65 & 59 & 65 \\
Latvia & 62 & 62 & 62 & 62 \\
Lithuania & 63 & 63 & 60 & 60 \\
Moldova & $\mathbf{6 2}$ & $\mathbf{6 2}$ & $\mathbf{5 7}$ & $\mathbf{5 7}$ \\
Poland & 65 & 65 & 60 & 60 \\
Romania & 64 & 65 & 59 & 60 \\
Russia & 60 & 60 & 55 & 55 \\
Ukraine & 60 & 60 & 55 & 60 \\
Average 2/ & 62 & 63 & 59 & 61 \\
\hline
\end{tabular}

Source: IMF (2011) and Moldovan Authorities.

1/ Age at which individuals can draw full benefits.

2/ Excluding Moldova.

16. The reform of the pension system should aim at achieving social sustainability while preserving fiscal sustainability in the medium and long-run. The key elements of the reform should include (i) systematic valorization of past earnings to halt the drop of the replacement rate, (ii) no further ad-hoc pension increases, and (iii) a necessary increase of retirement age for women to make any increase in benefits affordable.

\section{Pension reform simulations highlight the challenge of raising the replacement} rate while maintaining affordable fiscal balance. Two reform scenarios are compared to the baseline (Table 5). Under the baseline, the sharp drop in the replacement rate leads to a fiscally sustainable pension system in the long-term. However, such a sizeable drop in the replacement rate is socially undesirable. Reform scenario 1 assumes valorization of past earnings with inflation, reduction of accrual rates by 20 percent, an increase of women retirement age to 62 years over 10 years, and the indexation of self-employed and farmers contributions with nominal wage. ${ }^{5}$ This scenario allows medium to long-term fiscal sustainability with a higher replacement rate than under the baseline (Figure 3 and 4).

\footnotetext{
${ }^{5}$ Ad-hoc increases in accrual rates were used in the past to offset the lack of past earnings valorization.
} 
Reform scenario 2, which assumes a valorization of past wages with a 50-50 wage-inflation formula and a slightly different contribution for self-employed and farmers, yields an even higher replacement rate than reform 1 but at the cost of deteriorating long-term fiscal sustainability. While both scenarios would lead to initial moderate fiscal savings, they do point to the need of even bolder reforms in the long run to counter unfavorable demographics after 2030 and improve the social insurance function of the pension system without imposing an unaffordable fiscal burden.

Table 5. Moldova: Pension Reform Scenarios Simulated with the Pension Model

\begin{tabular}{|c|c|c|c|c|c|c|c|}
\hline Scenario & $\begin{array}{l}\text { Valorization of } \\
\text { past wages }\end{array}$ & Benefit indexation & Accrual rates & Retirement ages & Collection Rate & $\begin{array}{c}\text { Minimum pension } \\
\text { indexation }\end{array}$ & $\begin{array}{l}\text { Contribution for self- } \\
\text { employed and } \\
\text { farmers }\end{array}$ \\
\hline Baseline & $\begin{array}{c}\text { No valorization of } \\
\text { past earnings }\end{array}$ & $\begin{array}{c}50 \% \text { wages, } 50 \% \\
\text { inflation }\end{array}$ & $\begin{array}{c}1.4 \% \text { up to } 30 \text { years } \\
\text { of service, } 2 \% \text { beyond } \\
30 \text { years }\end{array}$ & $\begin{array}{c}\text { 62/57 years for } \\
\text { men/women }\end{array}$ & 90.0 & $\begin{array}{c}50 \% \text { wages, } 50 \% \\
\text { inflation }\end{array}$ & Based on a flat rate \\
\hline
\end{tabular}

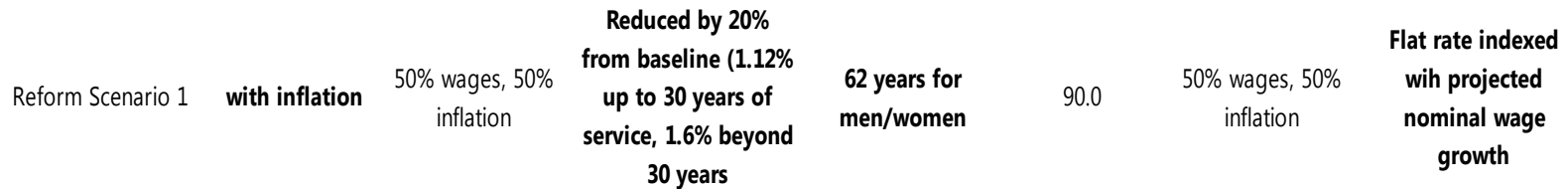

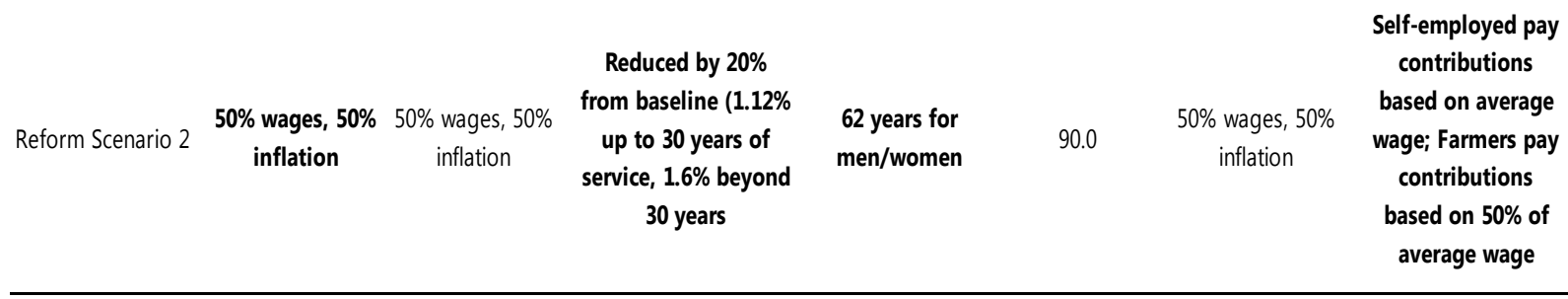

Source: Government of Moldova, Ministry of Labor, Social Protection, and Family and IMF staff.

Note: Parameters different from Baseline in the reform scenarios are in bold. 

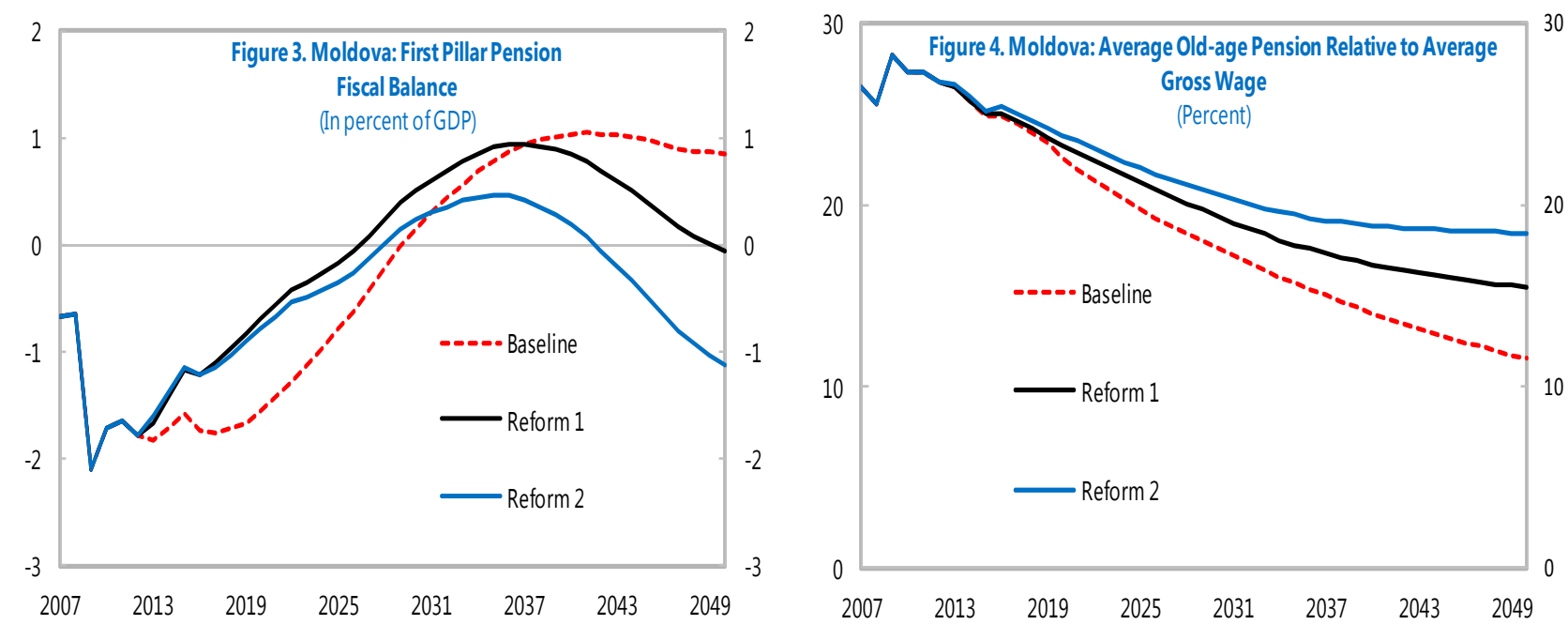

Sources: Government of Moldova, Ministry of Labor, Social Protection, and Family; and IMF staff.

\section{F. Public Administration Reform}

\section{Public sector employment in Moldova expanded relatively to its labor force. ${ }^{6}$}

Over the period 2000-10, public sector employment as a share of total labor force decreased in many CEE and CIS countries but increased in Moldova. From 21 percent of the labor force between 2000 and 2002, public sector employment in Moldova expanded to 26 percent in 2010, the highest in a broad sample of CEE and CIS countries (Table 6).

\footnotetext{
${ }^{6}$ The public sector in Moldova comprises central and local administrative units, health and social security funds, and state-owned enterprises.
} 
Table 6. Moldova and Selected Countries: Public Sector Employment, 2000-10

(In percent of Labor Force)

\begin{tabular}{|c|c|c|c|c|c|c|c|c|c|c|c|}
\hline & 2000 & 2001 & 2002 & 2003 & 2004 & 2005 & 2006 & 2007 & 2008 & 2009 & 2010 \\
\hline Armenia & 23.4 & 22.2 & 23.0 & 20.9 & 19.1 & 18.2 & 18.1 & 18.0 & 17.6 & .. & .. \\
\hline Azerbaijan &.. &.. &.. &.. &.. & 20.6 & 20.4 & 20.7 & 20.9 & 20.4 & 19.7 \\
\hline Belarus & 56.0 & 55.9 & 53.6 & 52.3 & 51.8 & 49.7 & 52.0 & 51.3 &.. &.. & .. \\
\hline Bulgaria & 26.9 & 24.6 & 22.7 & 23.1 & 21.9 & 20.5 & 19.6 & 18.7 & 17.5 & 17.5 &.. \\
\hline Croatia & 35.9 & 33.7 & 31.9 & 29.7 & 29.2 & 27.7 & 27.9 & 28.3 & 27.0 & .. & .. \\
\hline Czech Republic & 21.3 & 20.7 & 20.5 & 20.1 & 19.9 & 19.4 & 19.5 & 19.4 & .. &.. &.. \\
\hline Estonia & 24.9 & 25.5 & 24.3 & 24.0 & 23.5 & 22.9 & 23.9 & 23.2 & 22.7 & 23.3 & 22.3 \\
\hline Hungary & 20.5 & 20.6 & 21.1 & 21.2 & 21.1 & 20.9 & 20.5 & 19.9 & 19.7 & 20.3 &.. \\
\hline Kyrgyzstan & 20.1 & 19.3 & 17.4 & 16.9 & 16.5 & 15.9 & 14.0 & 14.1 &.. &.. &.. \\
\hline Latvia & 29.9 & 29.2 & 28.8 & 28.8 & 28.5 & 28.5 & 28.1 & 27.7 & 27.4 & 25.9 & 24.1 \\
\hline Lithuania & 28.7 & 27.8 & 26.8 & 27.7 & 27.4 & 27.0 & 27.2 & 26.9 & 26.5 & 25.4 & 24.5 \\
\hline Moldova & 21.0 & 21.0 & 20.9 & 23.1 & 23.7 & 23.8 & 25.0 & 25.1 & 25.1 & 25.6 & 26.0 \\
\hline Poland & 25.4 & 23.6 & 23.1 & 22.3 & 21.7 & 21.3 & 21.5 & 21.5 & 21.3 & 20.9 & 20.2 \\
\hline Romania & 29.7 & 27.0 & 22.7 & 24.0 & 23.4 & 21.6 & 21.6 & 19.5 & 18.8 &.. &.. \\
\hline Russia & 33.5 & 33.8 & 33.4 & 32.9 & 32.1 & 30.4 & 29.7 & 29.0 &.. &.. &.. \\
\hline Serbia &.. & 21.3 & 21.3 & 19.7 & 19.1 & 18.5 & 18.3 & 19.2 & 21.4 & 23.1 & 23.8 \\
\hline Slovakia & 25.4 & 25.1 & 23.8 & 22.3 & 20.8 & 20.1 & 19.7 & 19.4 & 18.8 & 18.4 & 18.5 \\
\hline Slovenia & 24.2 & 24.3 & 23.7 & 24.4 & 24.5 & 24.5 & 23.7 & 23.2 & 22.9 & 22.9 & 22.8 \\
\hline Ukraine &.. &.. & 20.2 & 20.7 & 20.1 & 20.1 & 20.2 & 20.1 & 20.2 & 20.4 & 21.0 \\
\hline Average 1/ & 27.9 & 26.8 & 25.5 & 25.2 & 24.7 & 23.8 & 23.7 & 23.4 & 21.8 & 22.0 & 22.3 \\
\hline
\end{tabular}

Source: ILO Statistics.

1/ Excluding Moldova.

\section{This increase mainly reflects a substantial decline in the labor force, not}

matched by a proportional decline in public sector employment. From 1.7 million

in 2000, the total labor force in Moldova declined by 25 percent over the following decade, driven by sizeable labor migration. During the same period, the total employment in the public sector declined by only 8 percent, from 348,000 in 2000 to 312,000 in 2010 .

20. Public employment in Moldova is relatively high in a number of sectors. The education sector stands out, placing Moldova as the country with the highest public employment in the sector (Table 7). ${ }^{7}$ Public employment in health is also relatively high, but this compensates for the scarcity of private health care. The relatively large public employment in transport and financial services reflects the unfinished privatization agenda. Employment in public administration (including defense and compulsory social security) represents the third largest source of public employment, about 4.4 percent of the total labor force in 2010. While this is a comparable level to peers in CEE and CIS, a close look reveals a lot of room for rationalization.

\footnotetext{
${ }^{7}$ Section $\mathrm{C}$ analyzes public employment and spending in the education sector.
} 


\section{The current administrative-territorial system is very fragmented, increasing} operational costs. The average size of municipalities in the country is considerably below the average of CEE countries (Figure 5). While the average size of a municipality is almost 15,000 inhabitants in CEE countries, municipalities in Moldova have on average five times less inhabitants. This leads to a relatively higher number of

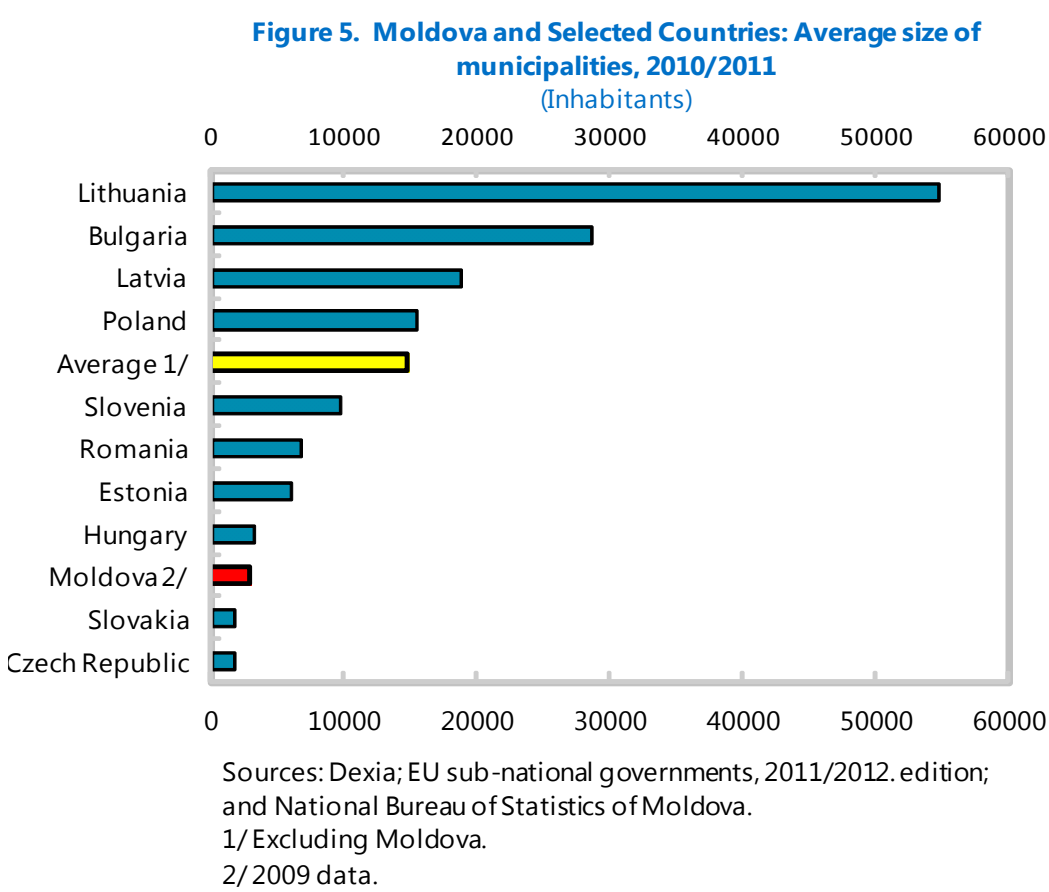
municipalities and larger operational costs.

\section{There is a long lasting and general trend towards reducing the number of} municipalities in European countries. Since the 1950s, most of the European countries have been reducing the number of their municipalities, creating larger administrative units. Between 1950 and 1992, Denmark reduced the number of its municipalities by 80 percent. This first round was followed by a second reduction by 64 percent between 1992 and 2011 . Other Western European countries such as Belgium and Sweden also implemented sizeable reductions in the number of their municipalities between 1950 and the early 1990s. Among CEE countries, Lithuania significantly reduced the number of its municipalities by 90 percent during the last two decades, and Latvia reduced by 78 percent the number of its municipalities over the last decade (Table 8).

\section{The number of municipalities increased in only few countries, including}

Moldova. The Czech Republic experienced a sizeable 52 percent increase of the number of its municipalities during the last decade. While this trend is uncommon, the number of municipalities in Moldova also increased by 11 percent between 1988 and 2011 (Table 8). 
Table 7. Moldova and Selected Countries: Public Employment by Sector, 2010 1/ (In percent of Labor Force)

\begin{tabular}{|c|c|c|c|c|c|c|c|c|c|c|c|c|c|c|}
\hline & Agriculture & Manufact. & $\begin{array}{c}\text { Electricity \& } \\
\text { Water }\end{array}$ & $\begin{array}{l}\text { Wholesale \& } \\
\text { Retail Trade }\end{array}$ & $\begin{array}{l}\text { Hotels \& } \\
\text { Restaurants }\end{array}$ & $\begin{array}{c}\text { Transport.\& } \\
\text { Communication }\end{array}$ & $\begin{array}{l}\text { Financial } \\
\text { Services }\end{array}$ & $\begin{array}{l}\text { Sciences \& } \\
\text { Techniques }\end{array}$ & $\begin{array}{l}\text { Public Admin., } \\
\text { Defense, Social } \\
\text { Security }\end{array}$ & Education & $\begin{array}{c}\text { Health \& } \\
\text { Social Work }\end{array}$ & $\begin{array}{c}\text { Arts \& } \\
\text { recreation }\end{array}$ & $\begin{array}{c}\text { Not } \\
\text { covered } \\
\text { elsewhere }\end{array}$ & Total \\
\hline Armenia & 0.2 & 0.0 & 0.2 & 0.0 & 0.0 & 1.1 & 0.9 & 0.0 & 3.7 & 8.1 & 2.5 & 0.0 & 0.8 & 17.5 \\
\hline Azerbaijan & 1.0 & 1.7 & 1.1 & 0.1 & 0.0 & 1.5 & 0.2 & 0.7 & 1.3 & 7.8 & 3.0 & 1.2 & 0.1 & 19.7 \\
\hline Bulgaria & 0.7 & 0.5 & 1.0 & 0.0 & 0.2 & 1.8 & 0.7 & 0.0 & 3.7 & 4.6 & 3.1 & 1.3 & 0.0 & 17.5 \\
\hline Croatia & 1.2 & 3.4 & 1.5 & 0.4 & 0.4 & 3.1 & 1.0 & 0.0 & 5.2 & 4.8 & 4.1 & 1.7 & 0.0 & 27.0 \\
\hline Estonia & 1.0 & 0.0 & 1.0 & 0.0 & 0.0 & 1.3 & 0.0 & 0.4 & 6.2 & 7.4 & 3.9 & 1.2 & 0.0 & 22.3 \\
\hline Hungary & 0.1 & 0.4 & 0.0 & 0.0 & 0.4 & 0.1 & 0.4 & 0.0 & 6.3 & 6.4 & 4.6 & 0.9 & 0.0 & 19.7 \\
\hline Latvia & 0.2 & 0.3 & 1.3 & 0.0 & 0.0 & 2.5 & 1.1 & 0.4 & 5.6 & 7.6 & 3.6 & 1.2 & 0.3 & 24.1 \\
\hline Lithuania & 0.3 & 0.2 & 1.1 & 0.0 & 0.0 & 1.7 & 0.2 & 0.7 & 5.4 & 9.0 & 4.9 & 1.0 & 0.0 & 24.5 \\
\hline Moldova & 0.7 & 0.4 & 0.8 & 0.1 & 0.2 & 2.3 & 1.6 & 0.0 & 4.4 & 9.5 & 4.8 & 0.0 & 1.3 & 26.0 \\
\hline Poland & 0.9 & 0.6 & 1.2 & 0.1 & 0.1 & 1.6 & 0.5 & 0.5 & 5.5 & 5.6 & 3.1 & 0.6 & 0.0 & 20.2 \\
\hline Romania & 0.9 & 1.0 & 0.9 & 0.2 & 0.0 & 1.8 & 0.7 & 0.0 & 5.2 & 4.1 & 3.5 & 0.6 & 0.0 & 18.8 \\
\hline Slovenia & 0.2 & 1.3 & 1.2 & 0.2 & 0.3 & 2.0 & 1.1 & 0.5 & 5.1 & 5.9 & 4.4 & 0.7 & 0.0 & 22.8 \\
\hline Ukraine & 0.0 & 0.0 & 0.0 & 0.0 & 0.0 & 0.0 & 1.2 & 0.0 & 5.5 & 7.4 & 5.8 & 0.0 & 1.2 & 21.0 \\
\hline Average 2/ & 0.6 & 0.8 & 0.9 & 0.1 & 0.1 & 1.5 & 0.7 & 0.3 & 4.9 & 6.5 & 3.9 & 0.9 & 0.2 & 21.3 \\
\hline
\end{tabular}

Source: ILO Statistics.

Agriculture also includes forestry, fishing, mining, and quarrying. Manufact. (manufacturing) includes construction. Electricity includes gas, steam, air conditioning supply, water supply, sewerage, and waste management.

$1 /$ or latest available.

2/ Excluding Moldova. 
Table 8. Moldova and Selected Countries: Change in the Number of Municipalities, 1945-2011

\begin{tabular}{|c|c|c|c|c|c|c|c|}
\hline & \multirow[b]{3}{*}{ Year } & \multirow{2}{*}{$\frac{1945-1980}{[A]}$} & \multirow[b]{3}{*}{ Year } & \multicolumn{2}{|l|}{$1988-2002$} & \multicolumn{2}{|c|}{2011} \\
\hline & & & & {$[\mathrm{B}]$} & {$[\mathrm{B}] /[\mathrm{A}]$} & {$[C]$} & {$[\mathrm{C}] /[\mathrm{B}]$} \\
\hline & & $\begin{array}{c}\text { Number of } \\
\text { municipalities }\end{array}$ & & $\begin{array}{c}\text { Number of } \\
\text { municipalities }\end{array}$ & $\begin{array}{l}\text { Percent } \\
\text { change }\end{array}$ & $\begin{array}{l}\text { Number of } \\
\text { municipalities }\end{array}$ & $\begin{array}{l}\text { Percent } \\
\text { change }\end{array}$ \\
\hline Lithuania & & & 1990 & 581 & & 60 & -90 \\
\hline Latvia & 1950 & 570 & 2002 & 542 & -4.9 & 119 & -78 \\
\hline Denmark & 1950 & 1387 & 1992 & 275 & -80.2 & 98 & -64 \\
\hline Netherlands & 1950 & 1015 & 1998 & 572 & -43.6 & 418 & -27 \\
\hline Finland & 1950 & 547 & 1993 & 455 & -16.8 & 336 & -26 \\
\hline Germany & 1950 & 25930 & 1994 & 14808 & -42.9 & 11553 & -22 \\
\hline United Kingdom & 1950 & 2028 & 1999 & 467 & -77.0 & 406 & -13 \\
\hline Estonia & & & 1990 & 254 & & 226 & -11 \\
\hline France & 1945 & 38814 & 1990 & 36763 & -5.3 & 36697 & 0 \\
\hline Belgium & 1950 & 2669 & 1991 & 589 & -77.9 & 589 & $\mathbf{0}$ \\
\hline Italy & 1950 & 7781 & 1999 & 8099 & 4.1 & 8094 & $\mathbf{0}$ \\
\hline Sweden & 1950 & 2281 & 1992 & 289 & -87.3 & 290 & 0 \\
\hline Spain & 1950 & 9214 & 1992 & 8082 & -12.3 & 8116 & 0 \\
\hline Poland & & & 1988 & 2399 & & 2479 & 3 \\
\hline Austria & 1950 & 3999 & 1992 & 2301 & -42.5 & 2357 & 2 \\
\hline Romania & & & 1998 & 2948 & & 3181 & 8 \\
\hline Moldova 1/ & & & 1988 & 881 & & 981 & 11 \\
\hline Czech Republic & & & 1990 & 4104 & & 6249 & 52 \\
\hline
\end{tabular}

Source: World Bank, 2003; Dexia, EU sub-national governments: 2009/2010 and 2011/2012 editions.

1/ Includes Transnitria.

Note: Shaded areas refer to Eastern and Central European Countries.

\section{The large number of municipalities in Moldova is associated with a very low}

\section{population density and large} operational cost. Out of 896

municipalities in 2008, excluding Transnistria, only 11 or 1 percent have more 20,000 inhabitants and just 12 percent have more than 5,000 inhabitants while the average size of municipalities in CEE countries is almost 15,000 inhabitants (Table 9). About 67 percent of Moldovan's municipalities have less than 3,000 inhabitants, and 40 percent have less than 1500 inhabitants. Small municipalities, with less than 3,000 inhabitants have an average operational cost per resident that is double or triple that of larger municipalities with more than 3,000 residents (Osoian et al. 2010).
Table 9. Moldova: Local Governments by Number of Inhabitants, 2008

\begin{tabular}{lccc}
\hline \multirow{2}{*}{ Number of inhabitants } & \multicolumn{3}{c}{ Number of municipalities } \\
\cline { 3 - 5 } \cline { 3 - 4 } & Urban/Towns & Rural & Total \\
\hline$<1,500$ & 1 & 236 & 237 \\
$1,501-3,000$ & 3 & 358 & 361 \\
$3,001-5,000$ & 6 & 182 & 188 \\
$5,001-10,000$ & 11 & 62 & 73 \\
$10,001-20,000$ & 22 & 4 & 26 \\
$20,001-50,000$ & 9 & - & 9 \\
$50,001-100,000$ & - & - & - \\
$100,001-200,000$ & 1 & - & 1 \\
$>200,001$ & 1 & - & 1 \\
Total & 54 & 842 & 896
\end{tabular}

Source: Osoian et al. 2010. 


\section{There is room to reduce the operational cost of the current territorial system} and improve its efficiency. Simply enforcing the existing legal provision requiring at least 1,500 inhabitants for a rural community to become a municipality (excluding exceptional cases) will significantly reduce the number of municipalities and their operational costs by at least 0.2 percent of GDP. Further reform to bring the average size of the municipalities in Moldova to the CEE countries' average will reduce municipalities operational costs by at least 0.6 percent of GDP. This reform will particularly facilitate the expansion of the education reform, which could generate even higher savings. ${ }^{8}$

\section{G. Further Education Reform}

26. The education system is mostly public in Moldova and most funding is provided by the central and local governments. Administration responsibilities are split between the Ministry of Education and local governments. The latter cover schools' operational and maintenance costs, helped by transfers from the state budget. The education system comprises pre-school, primary, secondary, and tertiary education, with a limited number of private and vocational schools and colleges.

\section{Education spending in Moldova is higher than in other countries. Moldova's} public spending on education is almost double the average in peer countries (Figure 6). The sharp increase in education spending despite the rapidly falling number of students explains the large gap between Moldova and its peers. Indeed, while the number of students declined by 27 percent between 2000 and 2010 , the number of schools and the number of teachers declined only marginally. ${ }^{9}$

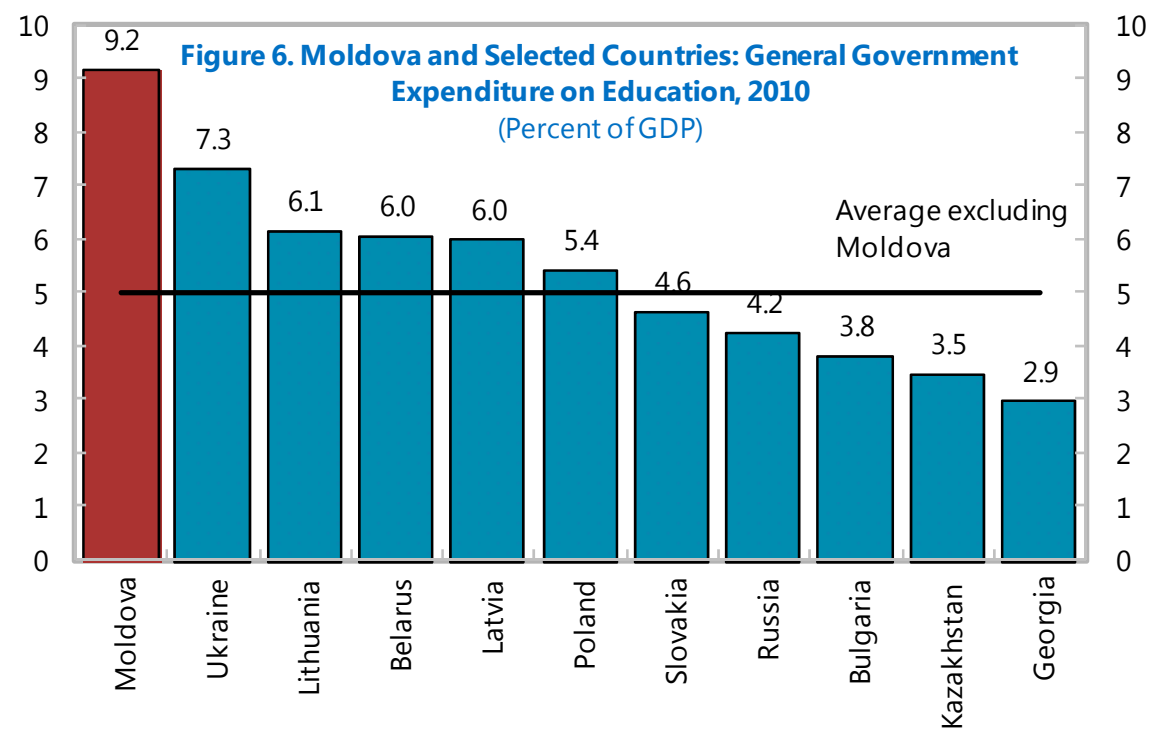

Sources: Government Finance Statistics; and IMF staff calculations. Various salary increases for teachers have also led to a sizeable 25 percent increase of the

\footnotetext{
${ }^{8}$ The education sector represented 60 percent of the consolidated local governments total expenditures between 2009 and 2011.

${ }^{9}$ The World Bank estimates the student-teacher ratio in Moldova to be only $2 / 3$ of the EU average. See "Moldova: Policy Notes for the Government", World Bank, October 2009.
} 
education wage bill in five years, from 4.7 percent of GDP in 2006 to 5.8 percent in 2010. The ratio of non-teaching to total staff is also well above the EU average.

\section{There is an ongoing reform in primary and secondary education, which} represents about half of the sector. In close cooperation with the World Bank, the government launched in 2011 a comprehensive medium-term reform of the oversized education sector. This reform focuses on primary and secondary education, which account for about 60 percent of total public spending in education (Table 10). The reform aims at rationalizing the sector by raising efficiency and improving quality through class size and school network optimization. Total net savings of 0.5 percent of GDP a year is expected from the reform upon completion. The reform is already important in supporting Table 10. Moldova: Educational Expenditure as a Percent of Total Educational Expenditure.

\begin{tabular}{lcccc}
\hline & Pre-primary & Primary & Secondary $1 /$ & Tertiary \\
\hline 2007 & $\mathbf{1 5 . 8}$ & 17.1 & 47.5 & $\mathbf{1 9 . 5}$ \\
2008 & $\mathbf{2 0 . 1}$ & 19.6 & 41.5 & $\mathbf{1 8 . 8}$ \\
2010 & $\mathbf{2 1 . 7}$ & 20.1 & 40.9 & $\mathbf{1 7 . 3}$ \\
\hline
\end{tabular}

Source: UNESCO Institute for Statistics (UIS) Database.

$1 /$ Includes post-secondary non-tertiary. the 2012 budget by enabling net savings worth 0.2 percent of GDP.

29. Spending in the remaining education sector is also high. Moldova's public spending in pre-primary and tertiary education, about 40 percent of the sector, is also significantly above the CEE countries' average (Table 11).

Table 11. Moldova and Selected Countries: Total public expenditure on educational institutions and administration, 2010 1/ (In percent of GDP)

\begin{tabular}{lccccc}
\hline & Pre-primary & Primary & Secondary 2/ & Tertiary & All level \\
\hline Bulgaria & 0.7 & 0.7 & 1.6 & 0.8 & 3.8 \\
Czech Republic & 0.4 & 0.6 & 1.9 & 0.9 & 3.8 \\
Estonia & 0.5 & 1.4 & 2.4 & 1.0 & 5.3 \\
Hungary & 0.7 & 0.8 & 2.2 & 0.9 & 4.6 \\
Latvia & 1.0 & 1.6 & 2.1 & 0.7 & 5.3 \\
Lithuania & 0.5 & 0.7 & 2.5 & 0.9 & 4.7 \\
Moldova & $\mathbf{1 . 8}$ & $\mathbf{1 . 6}$ & $\mathbf{3 . 3}$ & $\mathbf{1 . 4}$ & $\mathbf{8 . 2}$ \\
Poland & 0.6 & 1.6 & 1.9 & 1.0 & 5.0 \\
Romania & 0.4 & 0.8 & 1.5 & 1.1 & 3.8 \\
Serbia & 0.0 & 2.4 & 1.2 & 1.4 & 5.0 \\
Slovakia & 0.4 & 0.6 & 1.6 & 0.6 & 3.2 \\
Average 3/ & 0.5 & 1.1 & 1.9 & 0.9 & 4.5 \\
\hline
\end{tabular}

Source: UNESCO Institute for Statistics (UIS) Database.

1/ Or latest available. Excludes spending of social nature such as school feeding programs.

2/ Includes post-secondary non-tertiary.

3/ Excluding Moldova. 


\section{Expanding the reform to pre-primary and tertiary education could generate} significant savings. In collaboration with the World Bank, the education reform could be expanded to the remaining education sector. Potential gross savings from a reform based rationalization in the pre-primary and tertiary education that would bring Moldova in line with the average of CEE countries can easily exceed 1 percent of GDP.

\section{H. Conclusion}

\section{This paper has analyzed pre-crisis fiscal imbalances and recent developments} towards fiscal sustainability in Moldova. From a structurally weak fiscal position before the crisis, Moldova has been adjusting towards a sustainable position since 2010. The recent fiscal adjustment includes a comprehensive tax policy reform in 2012 with the reintroduction of the CIT, the extension of VAT refunds to the entire country, and excise increases in line with the EU integration agenda. It also includes expenditure rationalization measures such as wage and employment restraint, complemented by structural reforms in the education and social assistance sectors.

\section{Further reform-based rationalization of current expenditures remains the} priority to maintain fiscal sustainability and improve social equity. This paper identifies the pension system, the local public administration, and the education sector as the main areas for reform. Reform of the pension system could allow valorization of past earnings to ameliorate the decline of the replacement rates and address old-age poverty. However, this reform needs to be accompanied by an increase in the retirement age to preserve the fiscal integrity of the system. Local public administration reform to reduce the large number of municipalities can lower costs and improve service delivery by generating synergies. It could also facilitate the expansion of the education reform to the pre-primary and tertiary levels, generating fiscal savings and improving quality. Potential savings of about 2-3 percent of GDP from these three reforms would allow increasing much needed public investment and expanding targeted social assistance to support growth and preserve fiscal sustainability. 


\section{REFERENCES}

IMF, 2011, "The Challenge of Public Pension Reform in Advanced and Emerging Economies," IMF Board Paper (Washington: International Monetary Fund).

Karam, Philippe, 2010: "Republic of Moldova: Selected Issues Paper: Fiscal Consolidation and Structural Reforms in Moldova," IMF Country Report No. 10/232 (Washington: International Monetary Fund).

Osoian I., Sirodoev I., Veverita E., and Prohnitschi V., 2010, “Analytical Study on Optimal Administrative-Territorial Structure for the Republic of Moldova," Expert Grup Report.

Qehaja, Driton, 2012, "Fiscal Policy Response to External Crises: The Case of Moldova 1998-2010,” IMF Working Paper 12/82 (Washington: International Monetary Fund).

Ruud de Mooij and Michael Keen, 2012, "Fiscal Devaluation and Fiscal Consolidation: The VAT in Troubled Times," IMF Working Paper 12/85 (Washington: International Monetary Fund). 


\section{FDI Potential, Performance, and External Competitiveness ${ }^{1}$}

Contrary to a widespread view in the country, Moldova has had a good record in attracting FDI. Structural reforms implemented in 2010-11 boosted Moldova's competitiveness and growth potential. Further reforms aimed at broad-based improvements in competitiveness would be most efficient in promoting domestic and foreign investments. After its significant appreciation in 2011, the leu exchange rate has become mildly overvalued. However, moderate wage growth helped sustain external price competitiveness in 2010-11.

\section{A. Introduction}

1. Since 2009, Moldova's economic potential has strengthened considerably. The authorities have undertaken far-reaching structural reforms in several areas, including the tax system, education, pension and social assistance, the energy sector, external trade, and business regulation. With these reforms, the country advanced by 18 positions to rank 81 in the 2011/12 "Doing Business" survey compiled by the World Bank and came second in its list of top reformers in 2011. The reforms have raised the economic potential and sustained solid GDP expansion of 7.1 percent in 2010 and 6.4 percent in 2011.

2. Domestic consumption fuelled by remittances remained the main growth driver. Reflecting the post-crisis recovery in partner countries, remittances from Moldovan workers abroad increased by 13 percent in 2010 and 22 percent in 2011. These remittances, coupled with positive, if moderate, growth in income from domestic sources sustained strong private consumption expansion in 2010-11.

\section{The authorities' efforts to activate the second engine of growth based on} investment and exports have initiated important shifts in the economy. Gross fixed capital investment increased by 16 percent in 2010 and 9 percent in 2011 in real terms. Responding to recovering demand in partner countries and the government's efforts to promote trade integration, exports of goods and services increased by 15 percent in 2010 and another 38 percent in 2011 in US\$ terms. Breaking with a long declining trend, the share of value added in industry and agriculture increased to 26 percent of the total in 2011 from less than 22 percent in 2009.

\footnotetext{
${ }^{1}$ Prepared by Michael Gorbanyov and Svitlana Maslova.
} 
Figure 1. Moldova: Economic Developments, 1995-2011

GDP growth rebounded strongly in 2010-11, and labor productivity increased even faster.

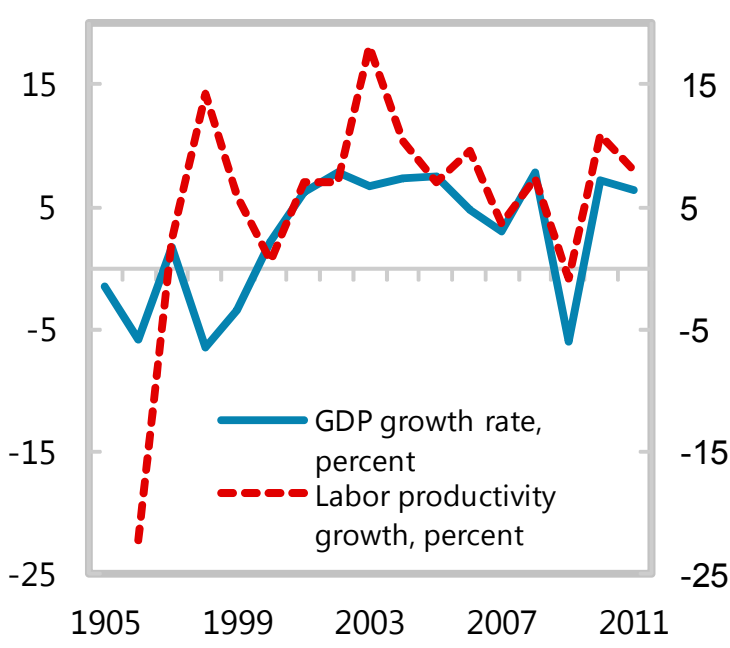

Exports increased in 2010-11, but imports increased even more, feeding private consuption.

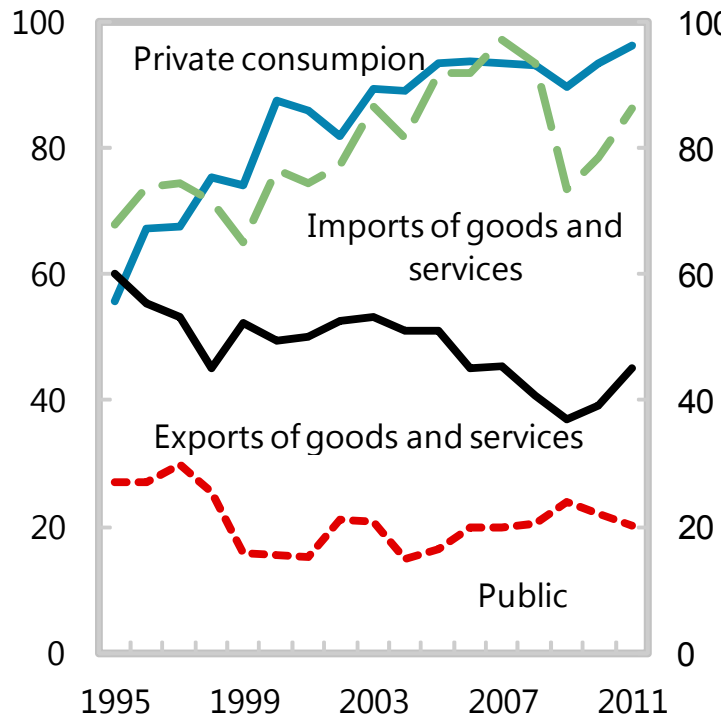

100
Even as domestic labor force declined, the share of remittances in GDP remained stable.

든롱 Unemployment,

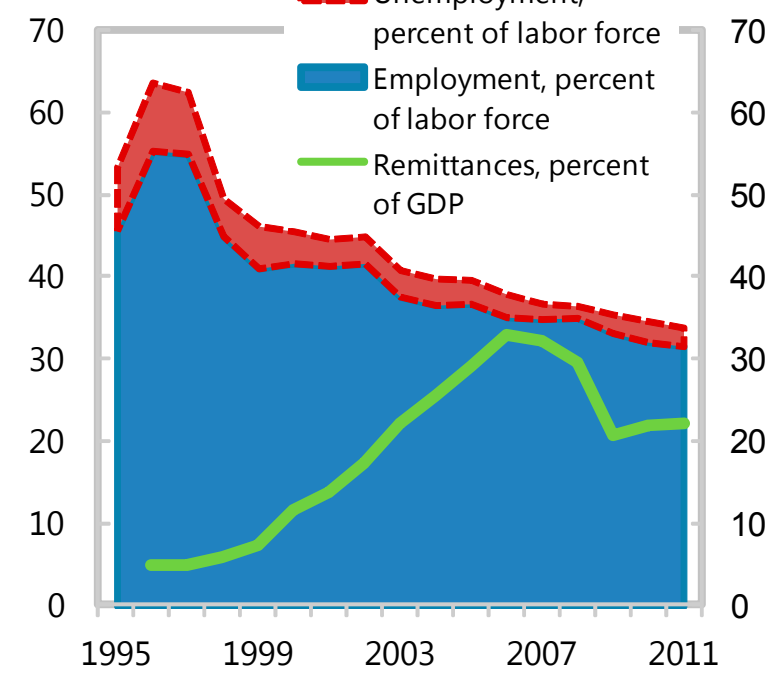

Wages increased broadly in line with productivity in 2010-11 and did not stoke inflation pressures.

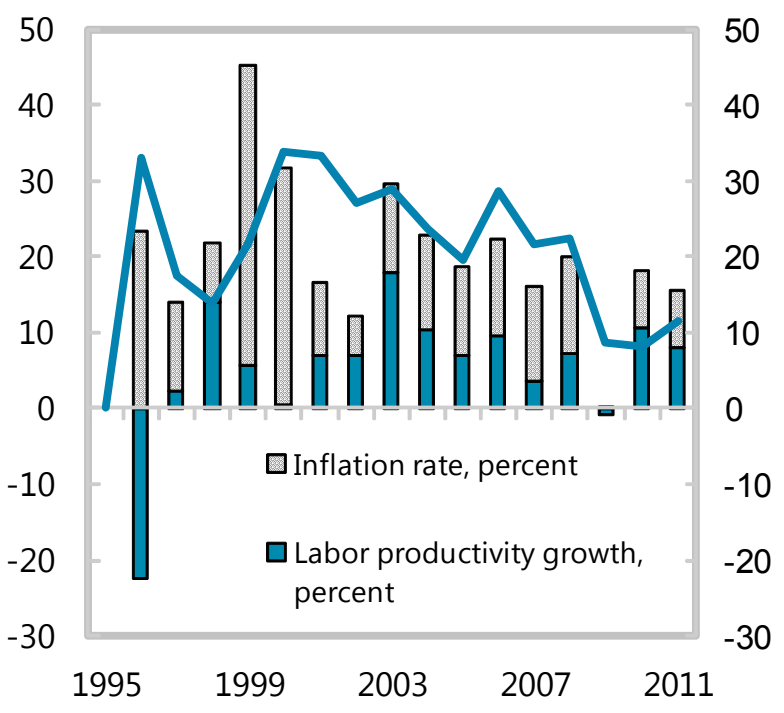

Sources: National Bureau of Statistics; and author's calculations. 
Figure 2. Moldova: GDP Composition and Investments, 1995-2011

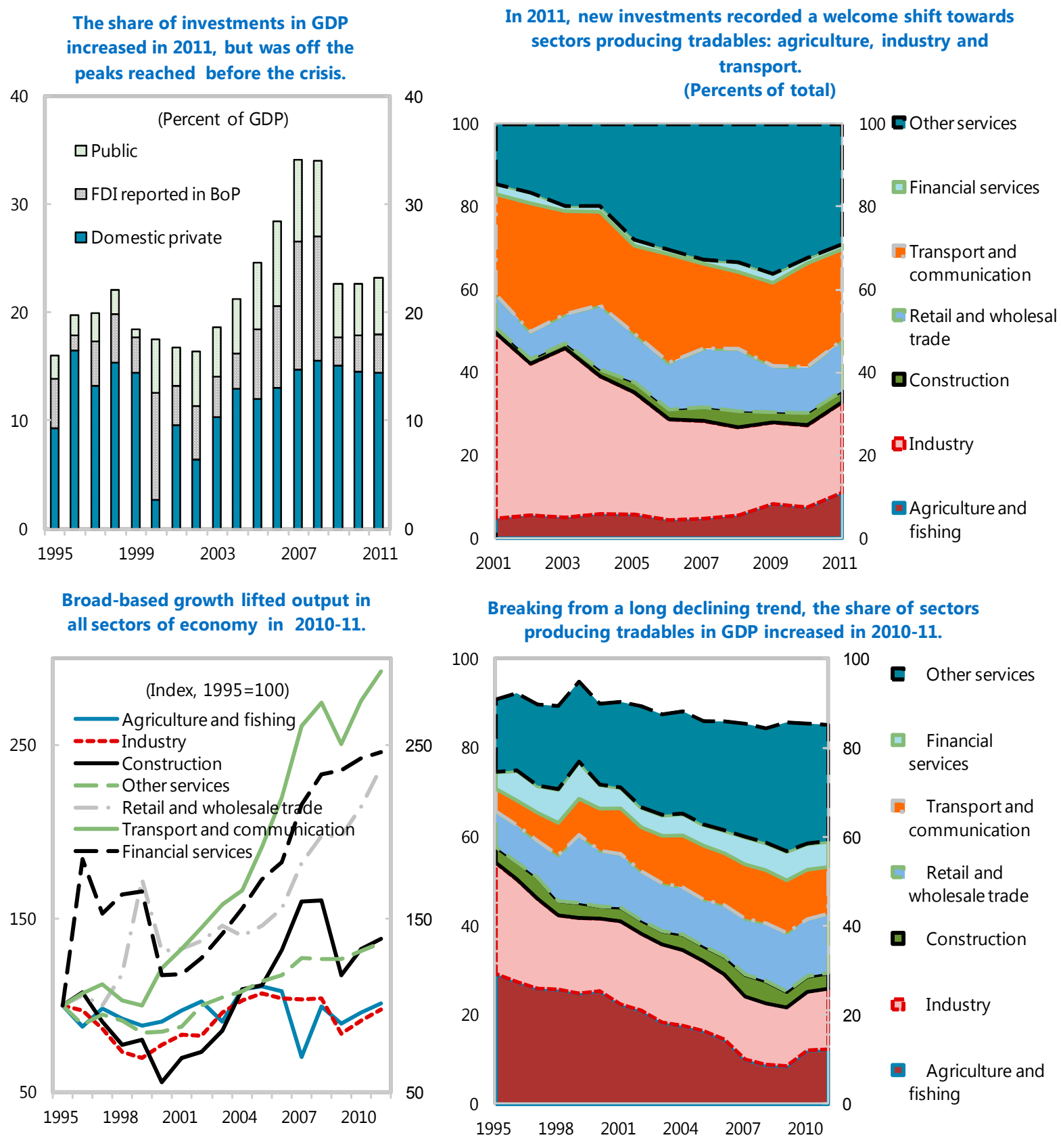

Sources: National Bureau of Statistics; and author's calculations.

\section{Productivity growth, rising remittances, and capital inflows led to currency}

appreciation. In real effective terms, the Moldovan leu appreciated by 5 percent in 2010 and another 10 percent in 2011. Should this trend continue, Moldova's exports' price competitiveness can be threatened. To sustain the high growth despite the loss of price competitiveness, it becomes even more important to accelerate structural reforms. 
5. The rest of the paper is organized as follows. Section B considers improvements in Moldova's competitiveness in recent years in comparison with peers in Europe and Asia. Section C updates the estimates of potential GDP growth and highlights recent changes in growth factors. Section D discusses progress in attracting FDI to Moldova and compares Moldova's experience with that of its neighbors. Section E analyses developments in price competitiveness of Moldova's exports. Section F provides a CGER-type exchange rate assessment. Section G concludes with a summary of the results and policy recommendations.

\section{B. Improvements in Competitiveness and Ease of Doing Business}

\section{Steady implementation of structural reforms has raised Moldova's}

competitiveness. In the 2011/12 edition of the World Bank's “Doing Business" survey, Moldova advanced from rank 99 to rank 81 and took second place in the list of top reformers worldwide for the year. This rapid progress reflected implementation of four reforms:

- A one-stop shop for business registration made starting a business easier;

- $\quad$ Private bailiffs made

Table 1. Moldova: Position in International Rankings

enforcement of court judgments more efficient (although some were controversially implicated in illegal bank takeover attempts);

- $\quad$ The first private credit bureau improved the credit information system;

\begin{tabular}{|c|c|c|}
\hline Survey & $\begin{array}{c}\text { Global } \\
\text { Competitiveness Index }\end{array}$ & $\begin{array}{l}\text { Doing Business } \\
\text { Ranking }^{1}\end{array}$ \\
\hline \multicolumn{3}{|c|}{ World Economic } \\
\hline Publisher & Forum & World Bank \\
\hline Position in 2008 & 95 out of 134 & $108 / 103$ out of 181 \\
\hline in 2009 & $n / a^{2}$ & $87 / 94$ out of 183 \\
\hline in 2010 & 94 out of 139 & $99 / 90$ out of 183 \\
\hline in 2011 & 93 out of 142 & 81 out of 183 \\
\hline
\end{tabular}

- $\quad$ The amended insolvency law granted priority to secured creditors.

However, Moldova advanced only slowly in the Global Competitiveness Index compiled by the World Economic Forum (GCI WEF; see 19 ).

\section{The sub-categories of the "Doing Business" survey show further details of} Moldova progress in improving competitiveness. In 2011, establishing of the credit bureau allowed Moldova to advance considerably in the "Getting credit" category. The country also advanced significantly in the "Starting a business" ranking. However, in other categories the advances were relatively small, and in certain rankings Moldova even lost grounds to competitors. As in the previous years, Moldova scored low in "Dealing with construction permits," "Trading across borders," and "Protecting investors." Even after the reforms implemented in so far, the international comparisons suggest ample room for further improvements in these areas. 


\section{As a result of the reforms, Moldova improved its competitive positions in the} region. When compared with peer economies in South-Eastern Europe and the CIS, Moldova advanced by two positions (from $8^{\text {th }}$ to $6^{\text {th }}$ place). In this peer group, Moldova retained high ranking in the "Enforcing contracts" category, but still scored poorly in "Protecting investors."

Table 2. Moldova and Selected Countries: Positions in "Doing Business" Survey, 2011

(For Moldova, ranks and positions of 2010 in brackets)

\begin{tabular}{|c|c|c|c|c|c|c|c|c|c|}
\hline & $\begin{array}{c}\text { Ease of } \\
\text { Doing } \\
\text { Business }\end{array}$ & $\begin{array}{c}\text { Starting a } \\
\text { Business }\end{array}$ & $\begin{array}{c}\text { Dealing with } \\
\text { Construction } \\
\text { Permits } \\
\end{array}$ & $\begin{array}{c}\text { Registering } \\
\text { Property }\end{array}$ & $\begin{array}{c}\text { Getting } \\
\text { Credit }\end{array}$ & $\begin{array}{l}\text { Protecting } \\
\text { Investors }\end{array}$ & Paying Taxes & $\begin{array}{c}\text { Trading } \\
\text { Across } \\
\text { Borders } \\
\end{array}$ & $\begin{array}{l}\text { Enforcing } \\
\text { Contracts }\end{array}$ \\
\hline Albania & 82 & 61 & 183 & 118 & 24 & 16 & 152 & 76 & 85 \\
\hline Armenia & 55 & 10 & 57 & 5 & 40 & 97 & 153 & 104 & 91 \\
\hline Azerbaijan & 66 & 18 & 172 & 9 & 48 & 24 & 81 & 170 & 25 \\
\hline Bosnia and Herzegovina & 125 & 162 & 163 & 100 & 67 & 97 & 110 & 108 & 125 \\
\hline Georgia & 16 & 7 & 4 & 1 & 8 & 17 & 42 & 54 & 41 \\
\hline Kyrgyz Republic & 70 & 17 & 62 & 17 & 8 & 13 & 162 & 171 & 48 \\
\hline Macedonia, FYR & 22 & 6 & 61 & 49 & 24 & 17 & 26 & 67 & 60 \\
\hline Moldova & $81(99)$ & $88(96)$ & 164 (164) & $18(19)$ & $40(96)$ & $111(108)$ & $83(79)$ & 134 (139) & $26(15)$ \\
\hline Mongolia & 86 & 97 & 119 & 26 & 67 & 29 & 57 & 159 & 33 \\
\hline Tajikistan & 147 & 70 & 177 & 90 & 177 & 65 & 168 & 177 & 42 \\
\hline Ukraine & 152 & 112 & 180 & 166 & 24 & 111 & 181 & 140 & 44 \\
\hline Uzbekistan & 166 & 96 & 145 & 136 & 159 & 133 & 157 & 183 & 43 \\
\hline Moldova's rank ${ }^{1}$ & $6(8)$ & $8(8)$ & $8(7)$ & $5(5)$ & $6(10)$ & $10(10)$ & $5(4)$ & $6(7)$ & $2(1)$ \\
\hline
\end{tabular}

Source: World Bank, "Doing Business" Survey.

${ }^{1}$ Rank among the 12 comparable countries with GNI per capita less than US $\$ 5,000$ in 2009 (1-best, 12 -worst).

\section{According to WEF, policy instability and corruption occupied the top places in} the list of most problematic

factors for doing business in

Moldova in 2011. The respondents

to the WEF's GCI survey placed

these factors above such traditional

factor as "Access to finance,"

which is often quoted as an

important limitation on the

business activity in developing

economies. They also named

inefficient bureaucracy and

government instability among the

top five factors problematic for

business. This highlights the areas

where reforms are badly needed.
Figure 3. Global Competitiveness Index: The Most Problematic Factors for Doing Business in Moldova

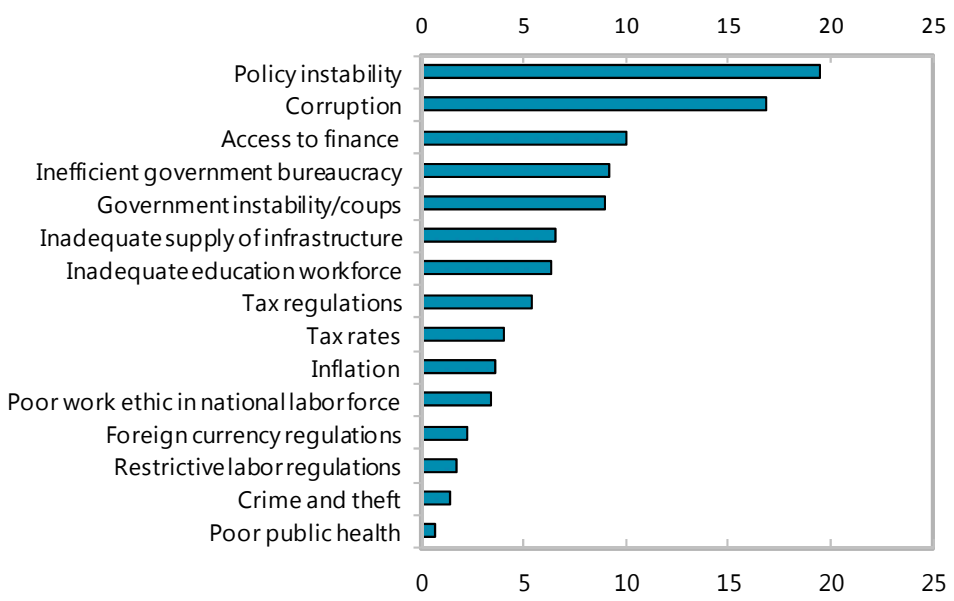

Source: World Economic Forum, Global Competitiveness Report. 


\section{Growth Potential and Engines of Growth}

10. The economic recovery surprised on the upside in 2010-11. In 2009, dearth of investments and dim prospects for productivity-enhancing reforms knocked potential GDP growth down to slightly above $3 \frac{1}{2}$ percent. In early 2010 , the IMF estimated potential growth at below 4 percent on average for 2010-15 (Gorbanyov et al., 2010). However, in the context of the IMF-supported program investment rebounded stronger than expected, and various productivity-enhancing reforms also proceeded faster than envisaged. As a result, estimated potential GDP growth has risen by a full percentage point above the earlier projection and would exceed 5 percent in the medium term.

Table 3: GDP Growth and Contributions, 2001-17

\begin{tabular}{|c|c|c|c|c|c|c|c|c|c|c|}
\hline \multicolumn{11}{|c|}{ (Percent) } \\
\hline & \multicolumn{2}{|c|}{ 2001-06 } & \multicolumn{2}{|c|}{$2007-08$} & \multicolumn{2}{|c|}{2009} & \multicolumn{2}{|c|}{$2010-15$} & \multicolumn{2}{|c|}{$2016-17$} \\
\hline & Actual & $\begin{array}{c}\text { Potential } \\
\text { (est.) }\end{array}$ & Actual & $\begin{array}{c}\text { Potential } \\
\text { (est.) }\end{array}$ & Actual & $\begin{array}{c}\text { Potential } \\
\text { (est.) }\end{array}$ & Proj. & $\begin{array}{c}\text { Potential } \\
\text { (proj.) }\end{array}$ & Proj. & $\begin{array}{c}\text { Potential } \\
\text { (proj.) }\end{array}$ \\
\hline Real GDP Growth & 6.7 & 3.6 & 5.4 & 5.5 & -6.0 & 3.6 & 5.3 & 4.7 & 5.3 & 5.2 \\
\hline \multicolumn{11}{|l|}{ Contributions: } \\
\hline capital & 0.9 & 0.9 & 2.5 & 2.8 & 0.7 & 0.9 & 1.9 & 1.9 & 2.4 & 2.4 \\
\hline labor & -1.6 & -1.2 & -0.1 & -1.1 & -3.4 & -1.0 & -0.5 & -0.8 & 0.0 & -0.8 \\
\hline productivity & 7.4 & 4.0 & 3.1 & 3.8 & -3.3 & 3.6 & 4.0 & 3.6 & 2.9 & 3.6 \\
\hline
\end{tabular}

Source: National Bureau of Statistics; and Staff calculations.

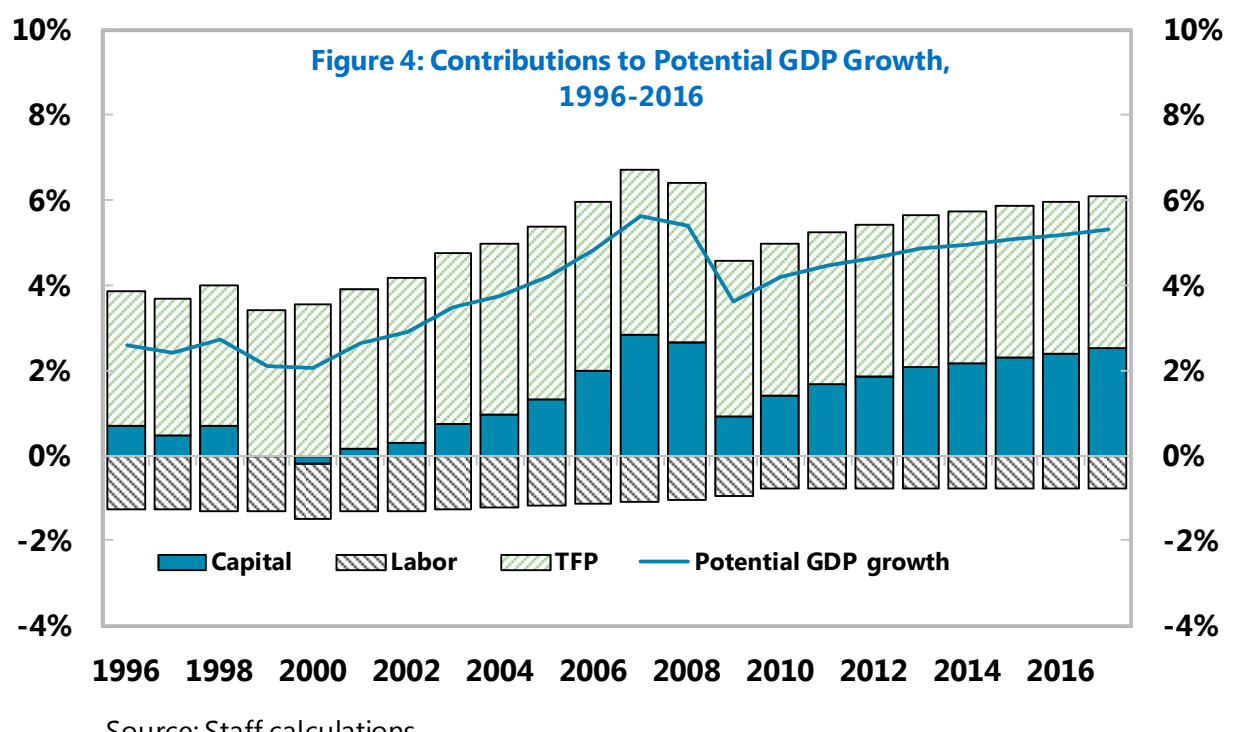

Source: Staff calculations.

11. The structure of Moldova's economy shapes the contribution of the production factors to the potential growth. Total factor productivity brings the largest input into the potential GDP growth. The second-largest contribution comes from the investment activity increasing the capital stock, which is rebounding after the crisis. Unfortunately, the steadily declining labor force continues to subtract from the economy's potential. 
12. Structural reforms and investments are the key to further increasing the growth potential of the economy. Accelerating the productivity-enhancing reforms can speed up the factor productivity convergence towards the level of more advanced neighboring countries. Improving business climate would support foreign and domestic investment. Finally, sustainable improvement in local business conditions should lead to new employment opportunities and real salary increases, which would stem outward labor migration.

\section{FDI Inflows: Drivers and Hurdles}

\section{Foreign investments in Moldova are comparable to those in other countries in} emerging Europe. FDI inflows to Moldova were on the rise for several years, reaching 1112 percent of GDP in 2007 and 2008. Even after the setback caused by the crisis, the stock of accumulated FDI in the Moldovan economy totaled around 50 percent of GDP at end-2011. Both in terms of inflows and accumulated stock of FDI, Moldova has outperformed many countries in the region, including more advanced economies with much higher GDP per capita that are in a better position to attract FDI.

Figure 5. FDI Inflows to Selected Countries, 2001-11

(Percent of GDP)

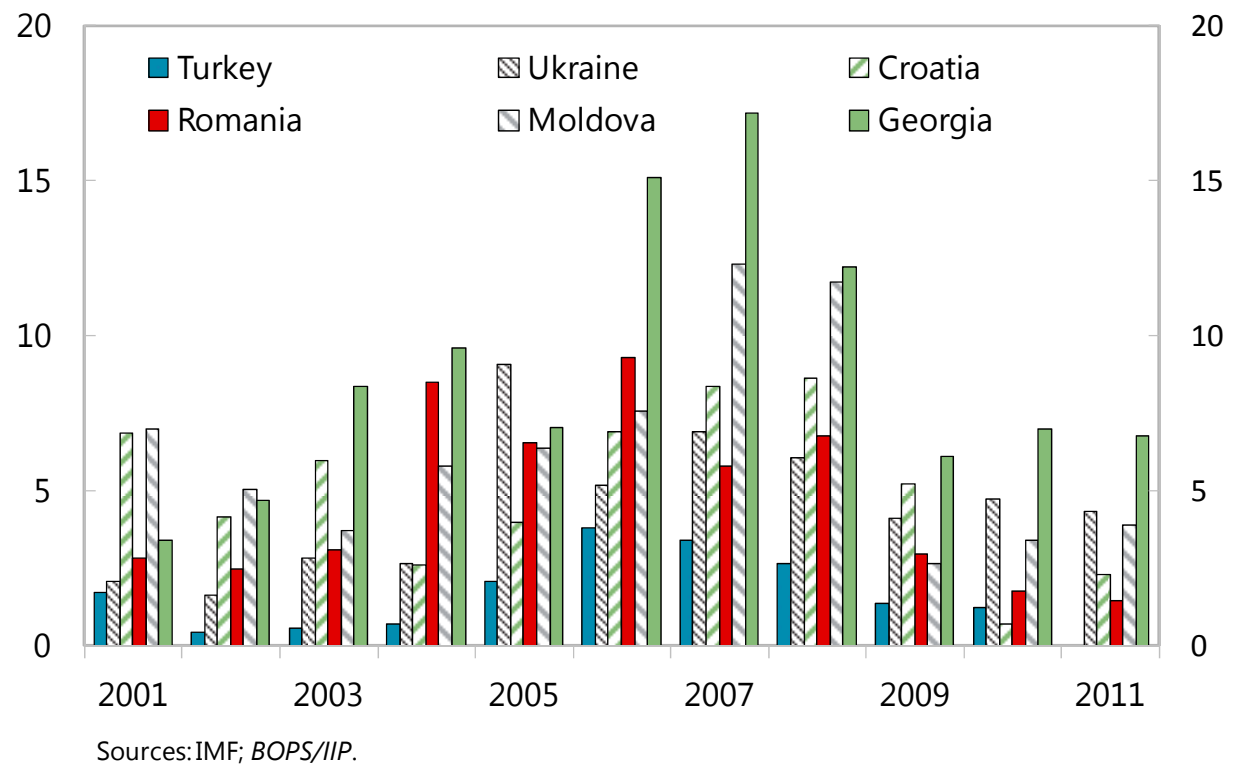


Figure 6. FDI to GDP Ratio and GDP per Capita in Selected Countries, 2010

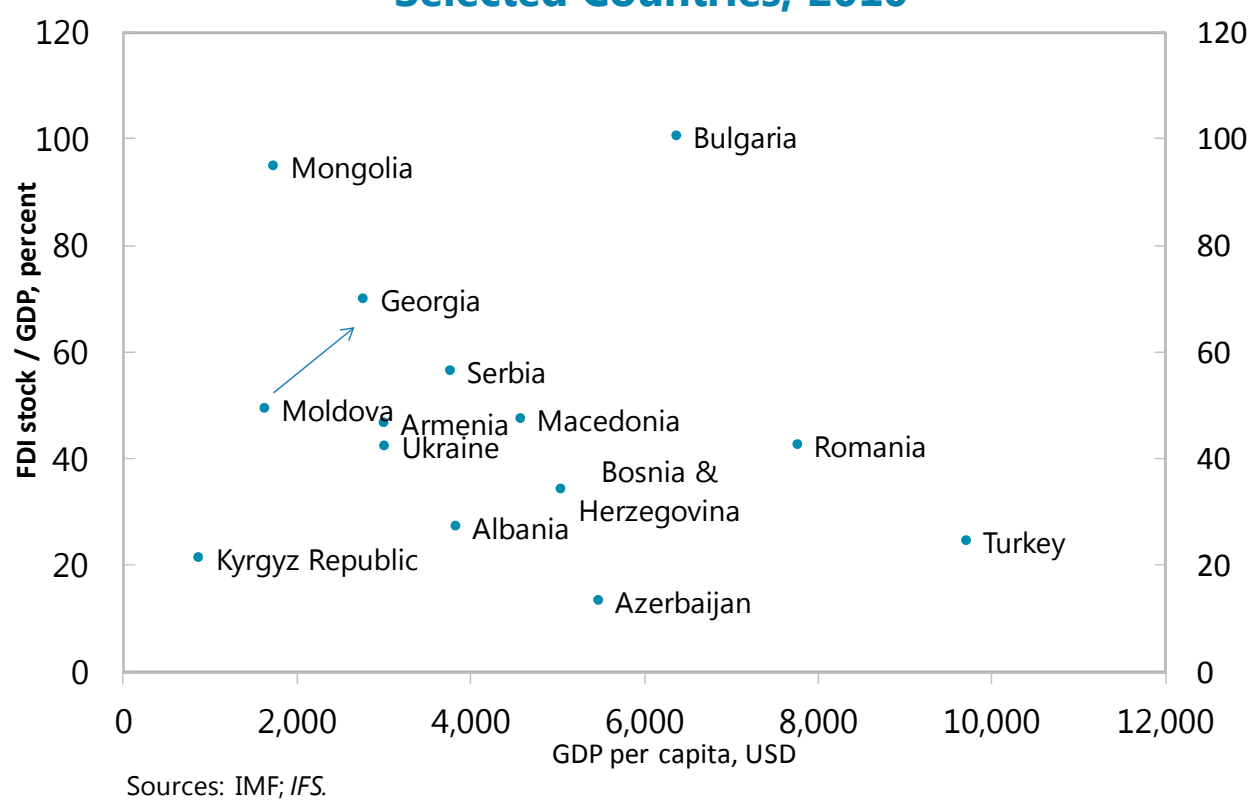

\section{Figure 7. FDI Performance and Potential Indices} for Selected Countries, 2008-10

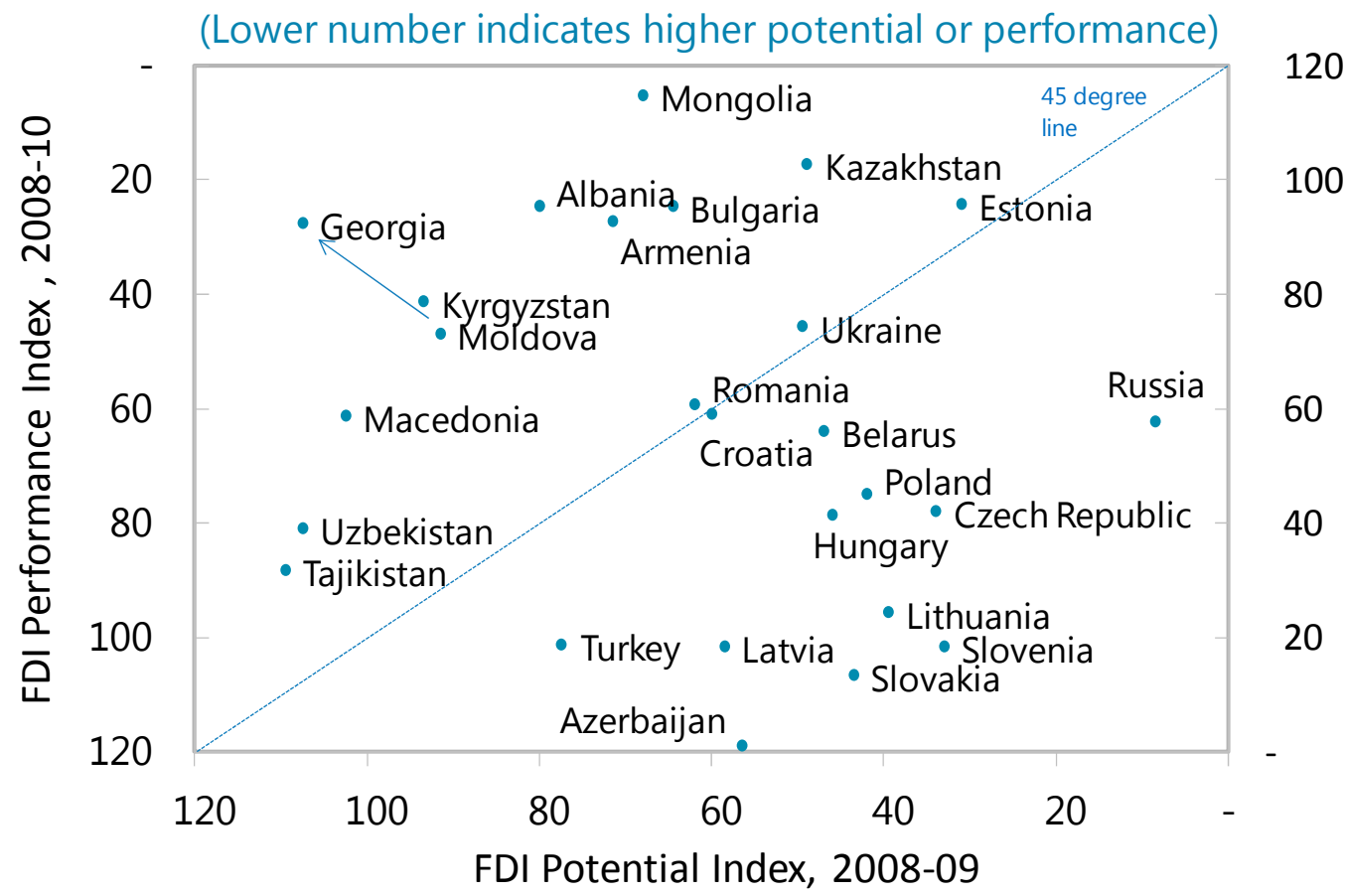

Source: UNCTAD, World Investment Report, 2011. 
14. This picture is broadly consistent with UNCTAD rankings, where Moldova's actual performance in attracting FDI is rated much better than its FDI potential. According to the United Nations Conference on Trade and Development (UNCTAD), in 2010 Moldova ranked $51^{\text {st }}$ in the world in attracting FDI relative to GDP. At the same time, in 2009 it took $96^{\text {th }}$ place in the FDI potential index, which ranked economies based on 12 variables reflecting their attractiveness to foreign investors (see the Appendix for the methodology).

\section{These findings contradict a widespread view in Moldova that the country} performs poorly in attracting foreign investors. Indeed, direct comparison of certain FDI indicators in Moldova, such as FDI per capita, with those of its more advanced neighbors can lead to such an impression. It also found support in early cross-country studies owing to Moldova's slow transition to a market economy (e.g., Demekas et al., 2005). However, such comparisons can be considered valid only when adjusting for important determinants of FDI potential, such as already achieved level of income per capita or availability of natural resources. When these factors are properly taken into account, one can see that Moldova is doing better or at least on par with peer countries in attracting FDIs.

16. Both academic literature and Moldova investors' surveys highlight access to the local and regional markets as the main reason for investing in Moldova. Enabled by large remittances and official assistance, total domestic demand accounts for about 140 percent of GDP in Moldova, much higher than in many comparable countries. In addition, Moldova's location on the frontier of the EU and CIS gives local companies access to markets in the East and West. Even though this access was often hindered by various obstacles, it was considered by foreign investors as an important positive factor (DablaNorris et al., 2010; Kudina and Jakubiak, 2011).

\section{The FDI distribution by sectors of economy confirms investor interest in} accessing the local market. In 2011, the sectors producing non-tradable goods and services accounted for more than three-quarters of the accumulated direct investments in the equity capital of the companies (Table 4). Their share was on the rise up to 2010, but an important deviation from this rising trend occurred in 2011, when the share of FDI in the tradable sectors increased somewhat. At least in part, this can be attributed to increasing FDI inflows in the free economic zones and ports. The pattern of FDI allocation was broadly consistent with the structure of Moldova's economy, where the share of key sectors producing tradables - agriculture and industry - declined to as low as 22 percent of GDP in 2009, but rebounded to 26 percent in 2011 (Figure 2). 
Table 4. Accumulated FDI in Equity Capital of the Companies in Sectors Producing Tradables and Non-tradables

(Percent of total)

\begin{tabular}{crrrrr}
\hline & Sep-07 & Sep-08 & Sep-09 & Sep-10 & Sep-11 \\
\hline Tradables & 26.6 & 25.3 & 24.3 & 21.1 & 22.7 \\
Agriculture & 1.0 & 0.8 & 1.1 & 0.9 & 1.3 \\
Industry & 25.6 & 24.5 & 23.2 & 20.2 & 21.4 \\
Non-tradables & 73.4 & 74.7 & 75.7 & 78.9 & 77.3 \\
\hline
\end{tabular}

Source: NBM, Balance of payments.

Figure 8. Moldova FDI Stock: Equity Capital by Main Source Countries, 2008 and 2011 (Millions of U.S. dollars)

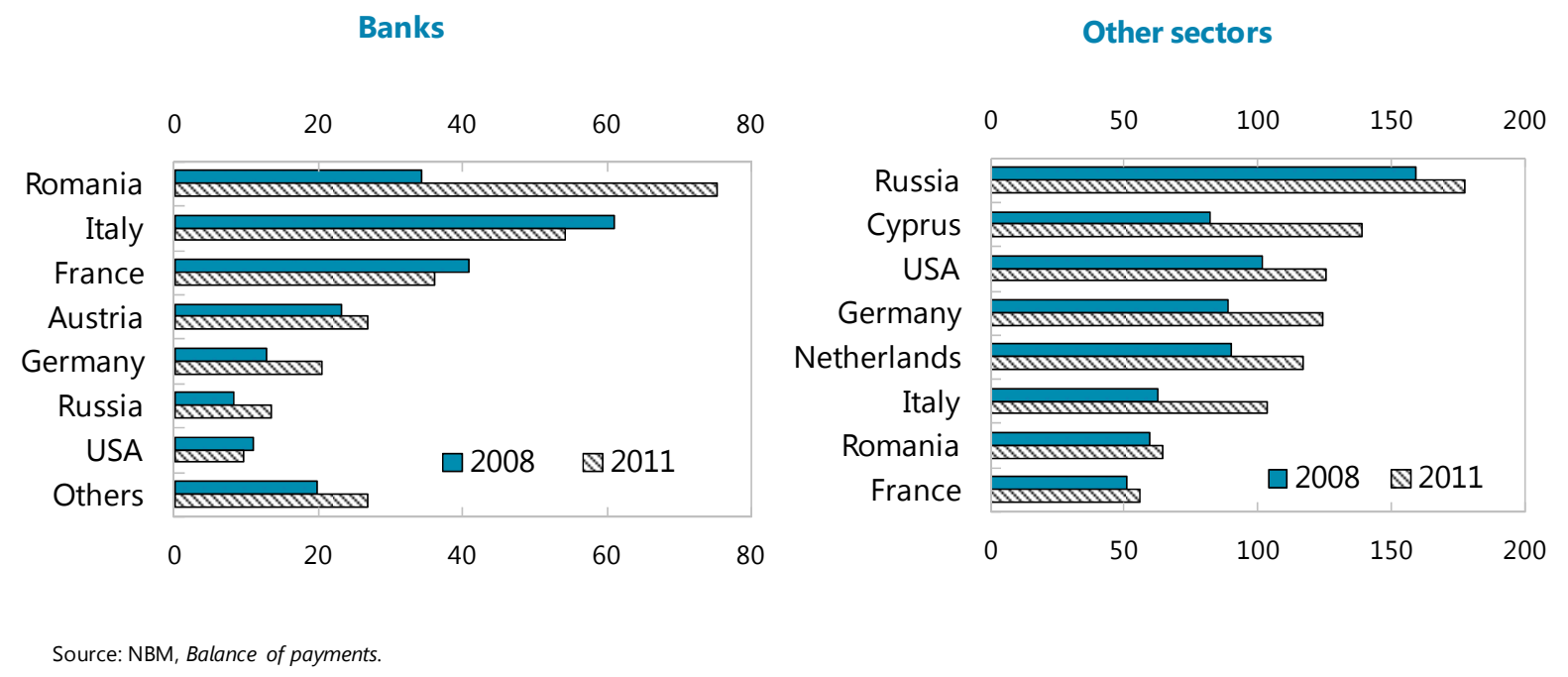

18. The source country distribution of the FDI to Moldova broadly follows the "gravitational" factors highlighted in the literature as the main drivers of FDI. The literature points to importance of such "gravitation" factors as GDP size, bilateral trade, and cultural links (Kinda, 2012). Not surprisingly, Romania takes the lead in bank capital investments. And Russia and Cyprus, which often serves as an off-shore platform for the companies of the CIS countries, lead in investments in the rest of the economy.

\section{Foreign investors play particularly important role in certain sectors of the}

economy. Out of the 14 banks in Moldova, 6 are fully or majority foreign-owned. In 2011, foreign and joint companies accounted for more than half of the value added produced in the communications sector and more than a quarter in trade, hotel, and restaurant business. Overall, foreign and joint companies accounted for more than 20 percent of investment in 2011, though this number came down from more than a quarter in 2010 and nearly a third in 2008-09. 
Table 5. Fixed Investments of Foreign and Joint Companies, 2001-11 (Percent of total)

\begin{tabular}{|c|c|c|c|}
\hline & Foreign & Joint & $\begin{array}{l}\text { Foreign } \\
\text { and joint }\end{array}$ \\
\hline 2001 & 9.5 & 24.4 & 33.9 \\
\hline 2002 & 5.2 & 19.8 & 25.0 \\
\hline 2003 & 4.9 & 20.7 & 25.6 \\
\hline 2004 & 9.7 & 21.9 & 31.6 \\
\hline 2005 & 8.8 & 19.9 & 28.7 \\
\hline 2006 & 12.7 & 14.2 & 26.9 \\
\hline 2007 & 12.8 & 18.9 & 31.7 \\
\hline 2008 & 13.2 & 18.3 & 31.5 \\
\hline 2009 & 9.7 & 17.6 & 27.3 \\
\hline 2010 & 10.4 & 16.9 & 27.3 \\
\hline 2011 & 8.8 & 12.4 & 21.2 \\
\hline
\end{tabular}

Source: NBS, Statistical Bulletin, JanuaryDecember 2011.
Table 6. Value Added Produced by Foreign and Joint Companies in Selected Industries, 2011 (Percent of total)

\begin{tabular}{lrrr}
\hline & & & Foreign \\
& Foreign & Joint & and joint \\
\hline Manufacturing & 14.4 & 24.4 & 38.8 \\
Construction & 2.3 & 3.5 & 5.8 \\
Trade & 8.1 & 19.5 & 27.6 \\
Hotels and restaurants & 14.4 & 13.8 & 28.2 \\
Transport & 3.0 & 5.0 & 8.0 \\
Communications & 1.6 & 51.9 & 53.5 \\
Real estate, leasing & 15.5 & 6.3 & 21.8 \\
Utilities, social services & -4.0 & 18.4 & 14.4 \\
\hline
\end{tabular}

Source: NBS, Structural Survey of Companies, 2011.

\section{The inflow of FDI in Moldova declined in 2010-11, in line with the regional}

trends. The "push" factors in the FDI source countries may have largely explained the surge in FDI to Moldova and other countries in the region in 2006-08 (Atoyan et al., 2012), while the weakening of these "push" factors may have been the main culprit behind the FDI deceleration after the crisis (Arbatli, 2011).

21. The same literature and survey that highlight the attractiveness of Moldova for FDI shed light on the remaining obstacles. The most urgent perceived problems were the volatility of the political environment, the uncertainty of the economic situation, the ambiguity of the legal system, and the high level of corruption (Kudina and Jakubiak, 2011). It is interesting to note that high level of taxation was not mentioned among the major impediments. In the same vein, availability of cheap labor force and other local inputs was mentioned among the positive factors, but was not the main reason attracting FDI to Moldova.

22. The main factors hindering FDI are the same as the main impediments to doing business in Moldova. Such obstacles as government instability and corruption feature prominently in both the responses of foreign investors and in broader business surveys conducted by WEF. This suggests the need for broad-based improvements in the business climate and competitiveness aimed at creating a level playing field with fair rules for both local and foreign-owned businesses. At the same time, these findings caution against providing special treatment and favorable conditions to certain investors and sectors, which 
can create fertile ground for rent-seeking, selective law application and enforcement, and outright corruption.

23. With the policies focused on improving the business climate, Moldova can aim to repeat the success of the regional leaders in attracting FDI, such as Georgia. This country implemented radical reforms aimed in improving international competitiveness and eradicating corruption. As a result, it advanced from $112^{\text {th }}$ position in 2004 to rank 37 in 2006 , and to $16^{\text {th }}$ place in the $2011 / 12$ "Doing Business" ranking (Box 1). Investors rewarded this progress by allocating large FDI to the country. The example of Georgia underscores that bold and ambitious reforms can drastically increase the country's attractiveness for foreign investors. The benefits of far-reaching reforms can outweigh the disadvantages of poor initial conditions and unfavorable geographic location.

24. Regional trade integration is another promising venue for attracting FDI. Access to the regional markets, particularly to the markets of the new EU member states and candidates, was an important factor cited by investors in Moldova. Widening the networks of trade agreements and speedy resolution of trade disputes with partner countries would help attract new investments in Moldova. One of the recent examples of success in this process was a decision of a foreign company to invest in the production of the automotive spare parts in Moldova for car assembly in the EU and possibly other countries. At the same time, the presence of trade preferences would not automatically trigger new investments. This was illustrated by the case of the EU meat and egg export quotas that remained unfilled for a number of years for the lack of supply meeting the EU standards.

\section{Privatization of public property is yet another reliable way to attract FDI.}

In 2012, the central government's privatization agency does not envisage privatization of large companies remaining in public ownership, such as national communications operator "Moldtelecom" (where a 92 percent stake belongs to the state), the large bank "Banca de Economii" (where the state has a 56 percent stake), and the national air carrier "Air Moldova" (fully owned by the state). Stakes in these and other large public companies can be attractive for foreign investors. 


\section{Box II.1. The Experience with Structural Reforms in Georgia}

The Georgian experience suggests that ambitious and comprehensive reforms can greatly improve the business environment and attract large FDI within 2-3 years.

In 2005-07, Georgia implemented bold reforms that radically improved the business climate. Georgia introduced a new company law and customs code to improve transparency and efficiency. A new tax code reduced the number of taxes from 21 to 9, including a CIT with 20 percent rate, a PIT with flat 12 percent rate, and social security contributions with an average rate of 20 percent. A new property registry replaced a confusing system requiring duplicate approvals by multiple agencies. The economy's first credit information bureau and large-scale judicial reforms aimed at eradication of corruption and arbitrary court decisions followed. As a result, Georgia leaped from $112^{\text {th }}$ to $21^{\text {st }}$ position in the "Doing Business" ranking within a few years.
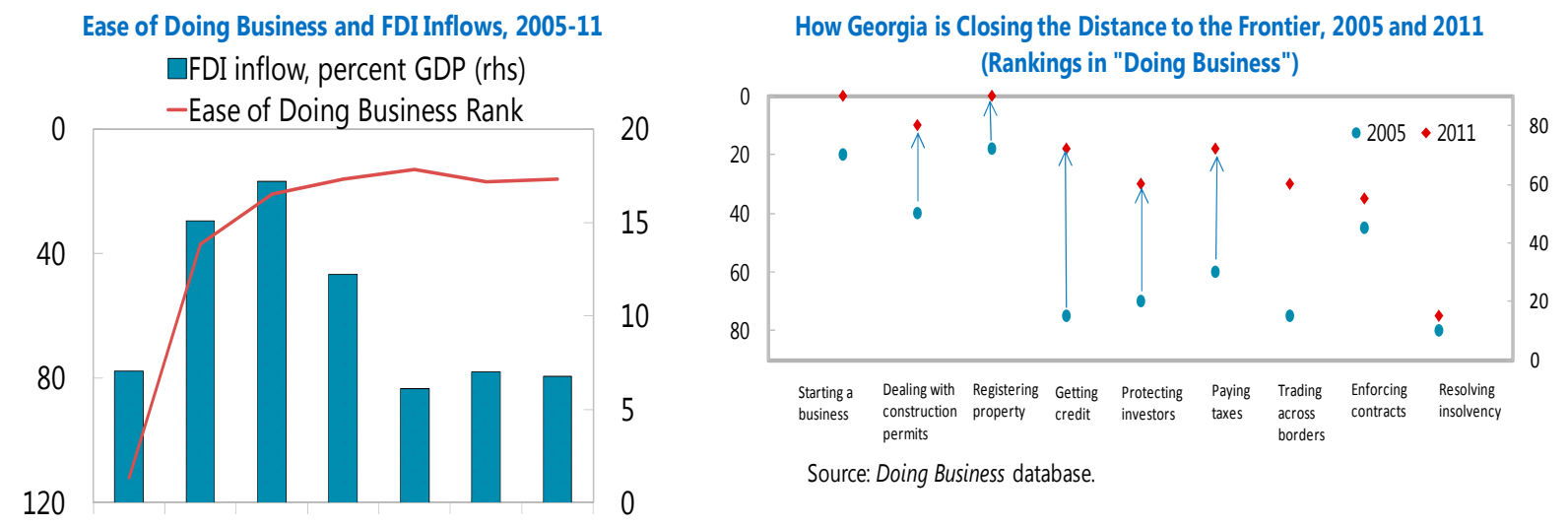

2005200620072008200920102011

The Georgian government enacted drastic anti-corruption measures. To fight corruption in the road police, it dismissed about 15,000 police officers, including the entire management team and all the heads of local units. In 2005 alone, the judicial disciplinary council reviewed cases against 99 judges, about 40 percent of the total, and 12 judges were dismissed. At the same time, judges' salaries were increased fourfold, to reduce the influence of bribes.

The reforms bore fruit. In 2008, Georgian firms recognized the low levels of bureaucracy and flexible business environment in enterprise surveys. Senior managers reported spending less than 2 percent of their time dealing with government regulations, down from about 10 percent in 2002 and the smallest share among economies in Eastern Europe and Central Asia. Only 4 percent of firms expect to make informal payments to public officials to get things done, compared with a regional average of 17 percent. Georgian firms participating in survey rounds in both 2005 and 2008 reported adding an average of 23 permanent workers (from 61 to 84 ) during that period. They also reported a big drop in contacts with tax officials, from an average of 8 in 2005 to only 0.4 in 2008.

Source: World Bank’s “Doing Business” reports, 2006-12. 


\section{E. External Price Competitiveness}

26. Even after considerable increases in recent years, labor costs in Moldova remain below that of its more advanced neighbors. This helped attract FDI in Moldova, even though it was not the key factor supporting investments (as discussed above). Wage increases and currency appreciation eroded somewhat this wage advantage of Moldova in the years before the crisis of 2009. Actually, the steepest increases in the unit labor costs (ULC) occurred in 2007-08, the years when Moldova benefitted from the highest FDI inflows. ${ }^{2}$

Figure 9. Average Wage in Selected Countries, 2000-11

(Manufacturing, U.S. dollars per month)

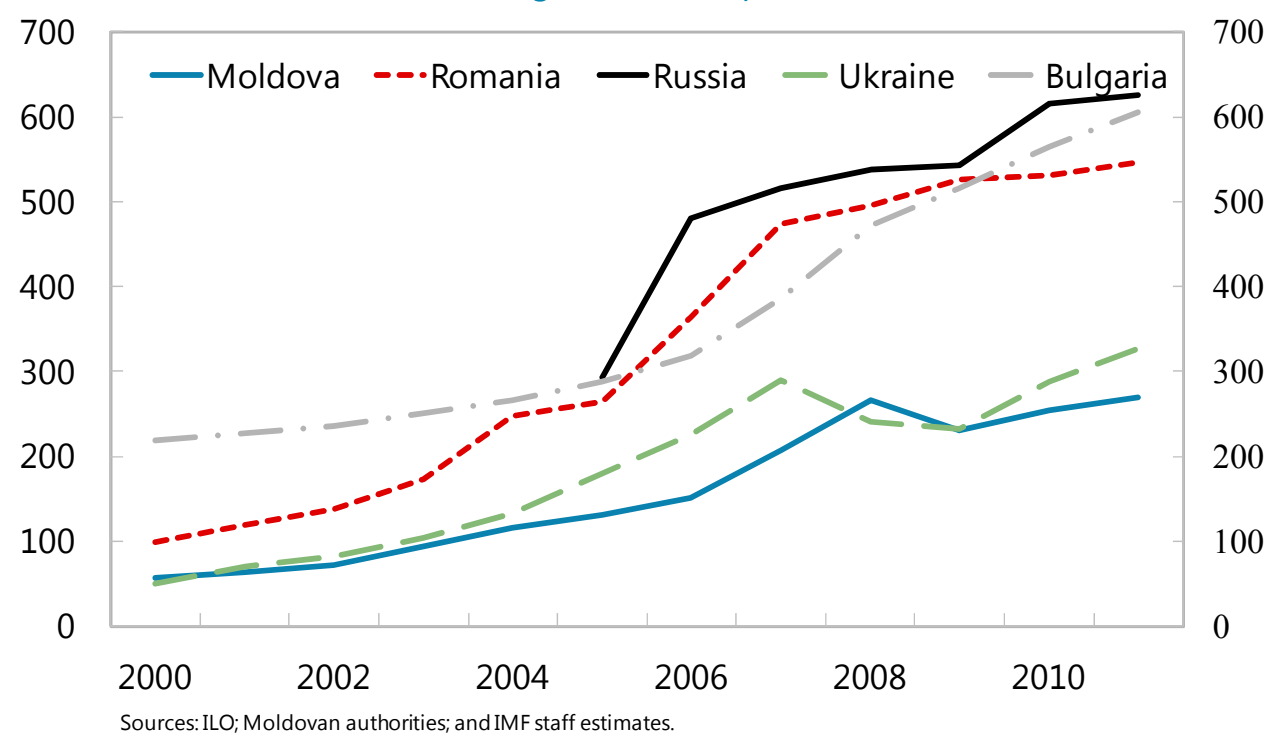

27. During and after the crisis of 2009, labor costs in Moldova experienced larger correction than in its trading partners. In the crisis, the ULC declined by as much as 20 percent amid their stability or smaller declines in the trade partner countries. The manufacturing wages expressed in U.S. dollar terms also declined in the crisis and increased significantly less thereafter than in other countries in the region (although perceived widespread underreporting of wages may overstate this effect). This helped restore Moldova price competitiveness and contributed to rebound in exports in 2010-11. That said, the distance to other CEE countries has declined considerably since 2000.

\footnotetext{
${ }^{2}$ The ULC data are from the Eurostat and local statistical bureaus. When unavailable, the ULC are calculated as a ratio of a product of seasonally-adjusted gross average wages and employment to GDP.
} 
Figure 10. Unit Labor Costs (y/y growth rate)

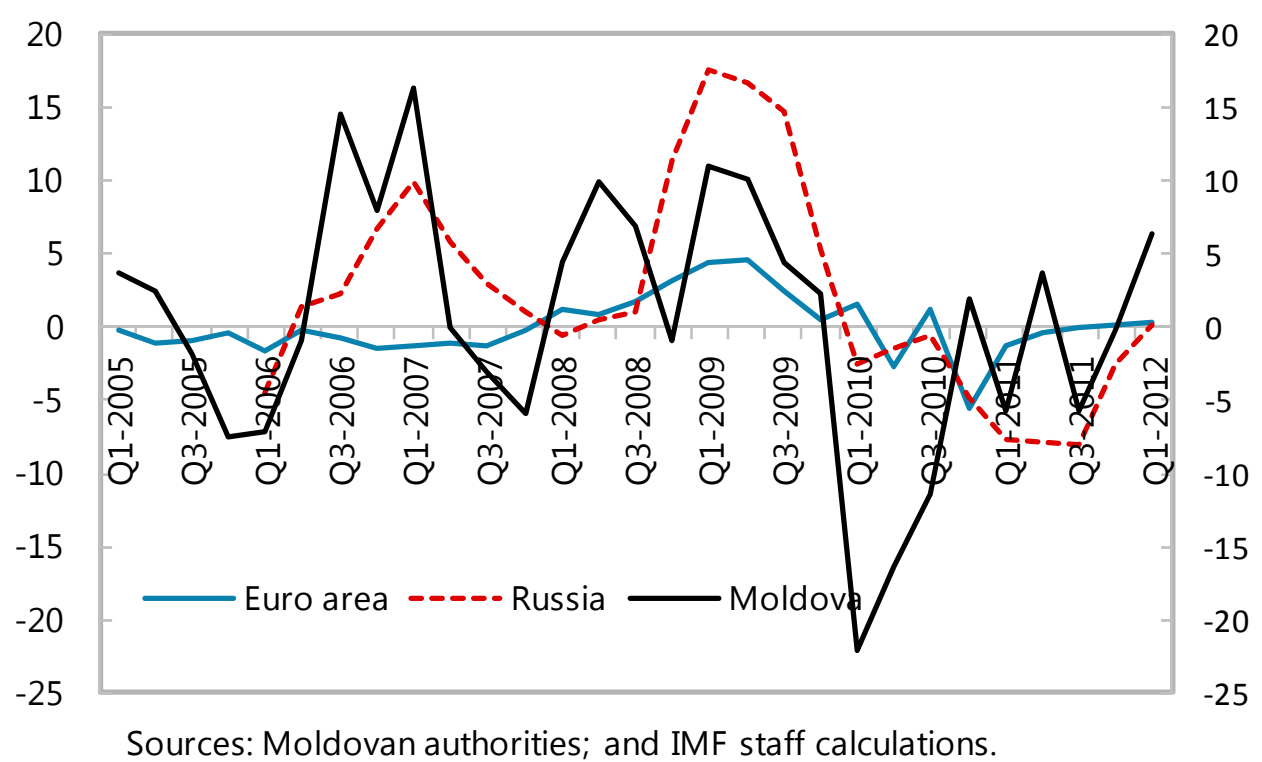

Figure 11. Unit Labor Costs in Selected Countries (Index, $2000=100$ )

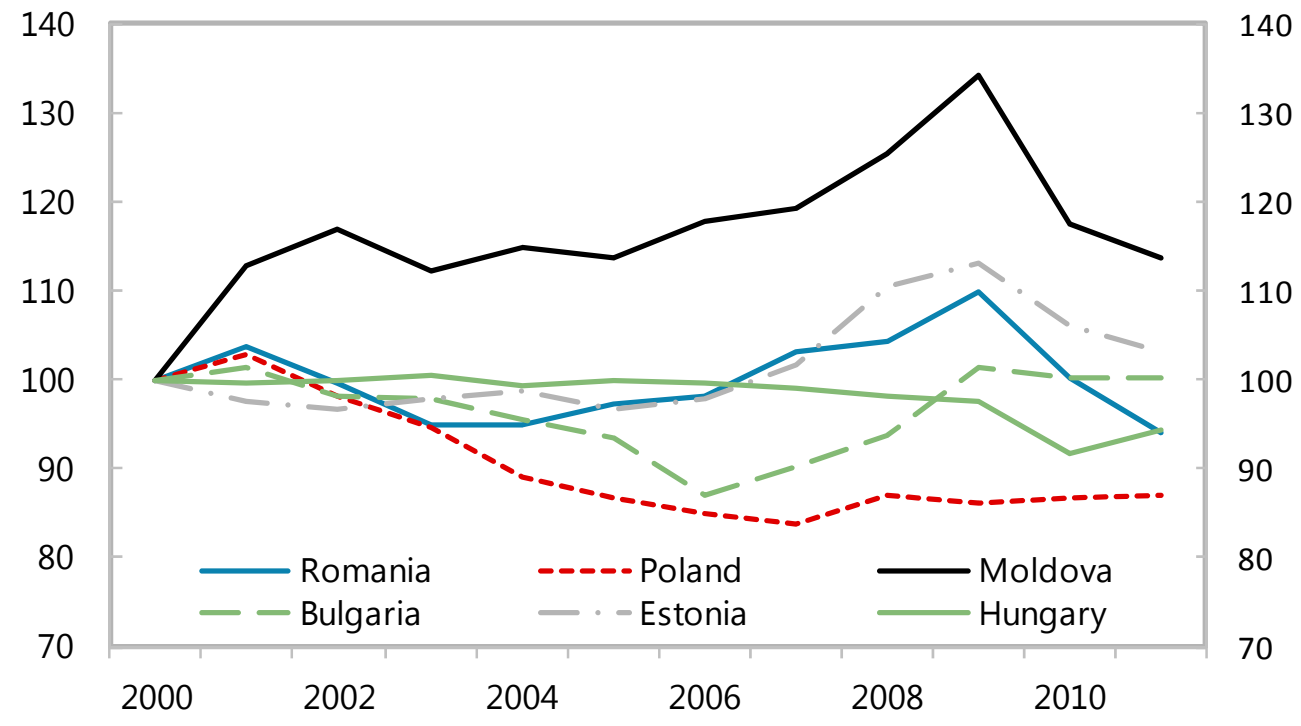

Sources: Moldovan authorities; and IMF staff calculations.

28. The crisis of $\mathbf{2 0 0 9}$ caused an adjustment in the real exchange rate of Moldova's leu, which was partly reversed in 2011. The CPI-deflated REER declined from its precrisis peak, helping to restore price competitiveness of Moldova's exports. However, it appreciated considerably again in 2011 before stabilizing at the end-2011 level in 2012 . This 
came in contrast with the developments in the key trading partners, thus creating risks for Moldova's external competitiveness.

Figure 12. Real Effective Exchange Rates: Country Comparison

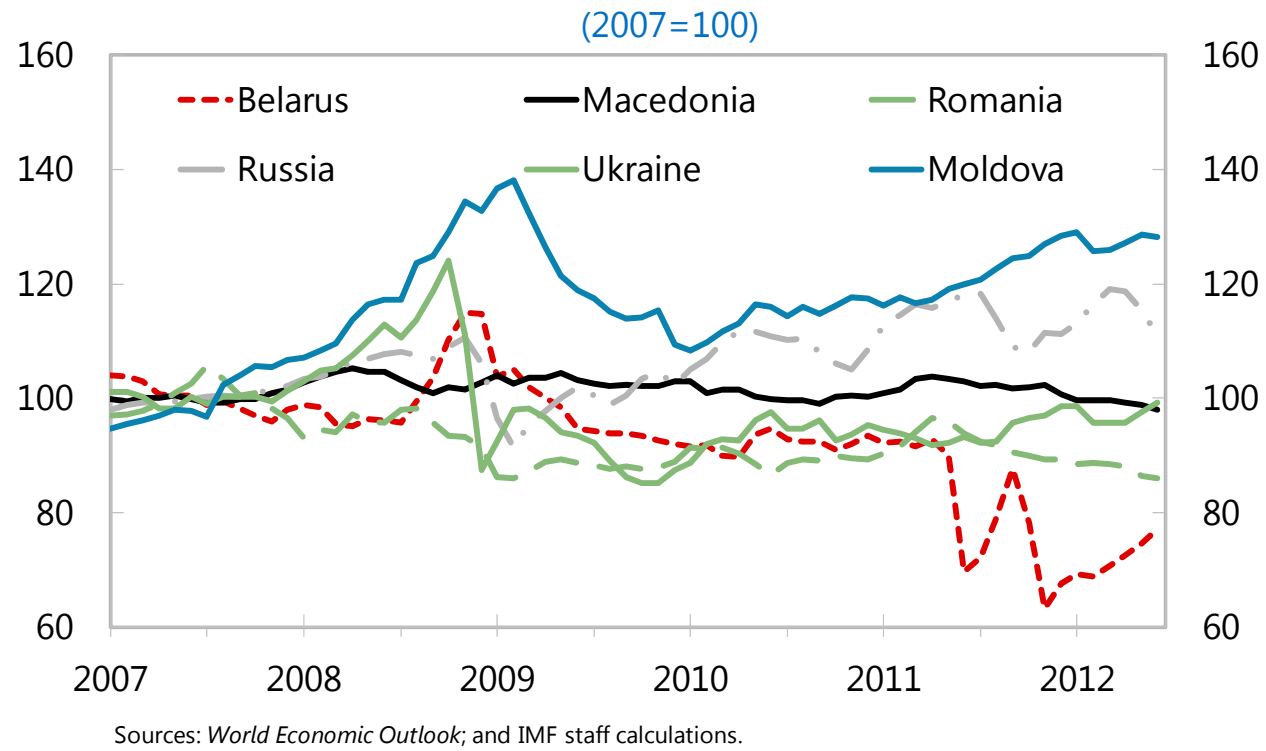

29. The ULC-deflated REER followed broadly the same pattern, but appreciated less in 2011. It appreciated considerably in the 2005-08 period, but underwent a larger correction during the crisis than the CPI-deflated REER. Importantly, the ULC-deflated REER appreciated only modestly in 2011, suggesting much less loss of competitiveness for sectors of the economy where labor is the key input into the production.

Figure 13. Real Effective Exchange Rates, 2005-12
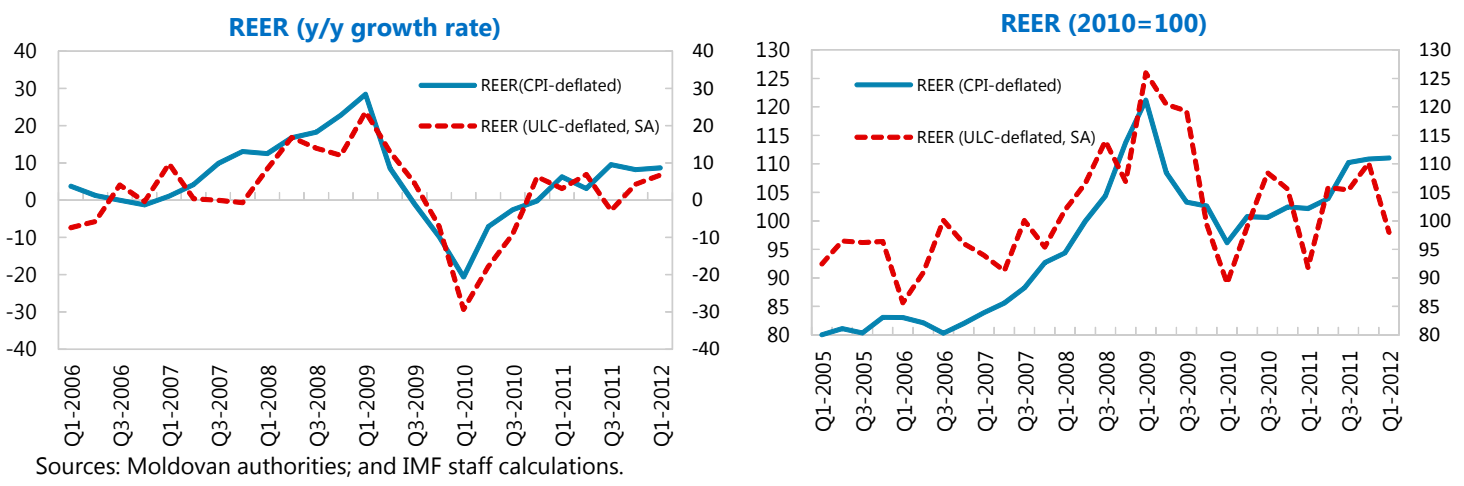


\section{F. CGER-type Exchange Rate Assessment}

\section{After its considerable appreciation in 2011, the CPI-based REER appears}

moderately overvalued. The external sustainability method estimates the current account deficit that would stabilize NFA at minus 55 percent of GDP at 5.1 percent of GDP compared with the projected deficit of 9.5 percent of GDP in $2017 .{ }^{3}$ This translates into the leu overvaluation by 7.8-14.3 percent, depending on the elasticity used (Table 8). Based on the macro balance (MB) approach, the current account deficit norm is estimated at 6.7 percent of GDP compared to structurally-adjusted underlying deficit of -9.5 percent of GDP, suggesting leu overvaluation of 4.8 to 8.9 percent. The equilibrium exchange rate (ERER) method points at the leu overvaluation of 9.9 percent. The ERER estimate is based on the panel estimation along the lines in Vitek (2009); the main contributors to the estimated overvaluation are the initial NFA position and relative productivity.

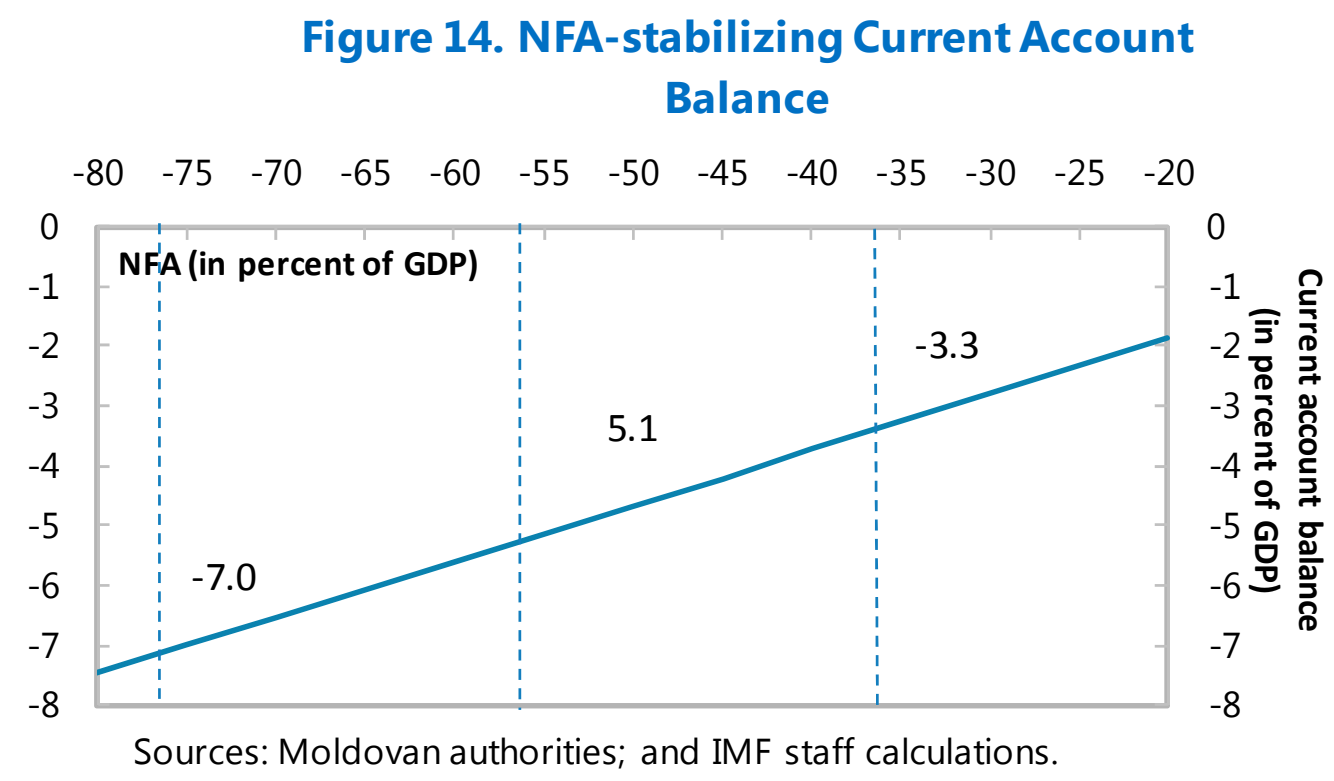

\footnotetext{
${ }^{3}$ Minus 55 percent of GDP is the median of the NFA positions in a few CEE countries, which is considered a relevant long-term benchmark for Moldova. The current account deficit which would stabilize the NFA position at its end-2011 level (-75 percent of GDP) is estimated at 7.0 percent of GDP. On the other hand, a current account deficit of only 3.3 percent will be necessary to stabilize the NFA position at -35 percent of GDP, the European Commission's benchmark used in their assessment of macroeconomic imbalances.
} 
Table 7. Estimates of Overvaluation of the lei

\begin{tabular}{lc}
\hline \multicolumn{1}{c}{ Approach } & $\begin{array}{c}\text { Estimated overvaluation } \\
\text { (in percent) }\end{array}$ \\
\hline External sustainability & 7.8 to 14.3 \\
Macro balance & 4.8 to 8.9 \\
Equilibrium exchange & 9.9 \\
\hline
\end{tabular}

Source: Staff estimates.

Table 8. Estimation of the Trade Balance Elasticity for Moldova 1/

\begin{tabular}{lrr}
\hline & $\begin{array}{c}\text { CGER for } \\
\text { industrialized } \\
\text { countries }\end{array}$ & Gerling (2011) 2/ \\
\hline Export elasticity & -0.71 & -1.60 \\
Import elasticity & 0.92 & 0.99 \\
Pass-through to exports & 1.00 & 0.10 \\
Pass-through to imports & -1.00 & -0.51 \\
Trade balance elasticity & -0.30 & -0.56 \\
\hline
\end{tabular}

Source: IMF staff estimates.

1/ Export and import shares in GDP are set at 53 and 91 percent, respectively, as projected for 2017.

2/ Moldova-specific estimates.

\section{All these methods suggest that a current account deficit of about 5-7 percent of} GDP would be consistent with a safe external position in the long run. The external sector and macro balance approaches estimate the current account norm at about this level. Moreover, the available non-debt creating flows (FDI) in the medium term are projected at 6 percent of GDP. At a minimum, the debt sustainability (DSA) framework suggests that a non-interest current account deficit of 8 percent of GDP is necessary to stabilize the country's external debt at its presently high level (64 percent of GDP).

\section{Moldova's negative Investment International Position (IIP) narrowed somewhat} in 2011 to 75 percent of GDP. However, it stayed above the pre-crisis levels and levels in the comparator countries. The improvement came from a decrease in the international liabilities relative to GDP. The external debt stock in terms of GDP also declined from 67 percent in 2010 to 64 percent in 2011 (the stock of private and public debt increased by 17 percent and 11 percent year-on-year, respectively, while the GDP measured in US\$ terms rose by 20 percent). 
Figure 15. International Investment Position, 2003-11

(Percents of GDP)

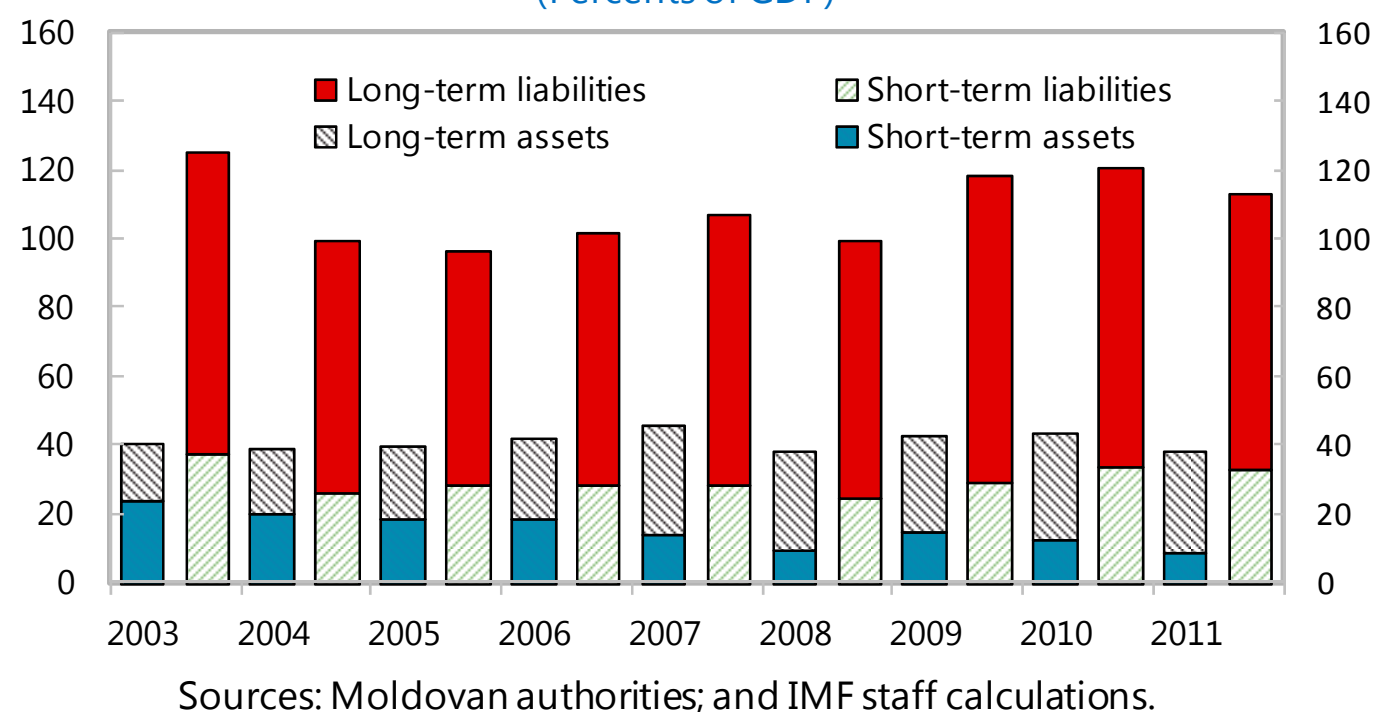

Figure 16. International Investment Position, 2002-11

(Percents of GDP)

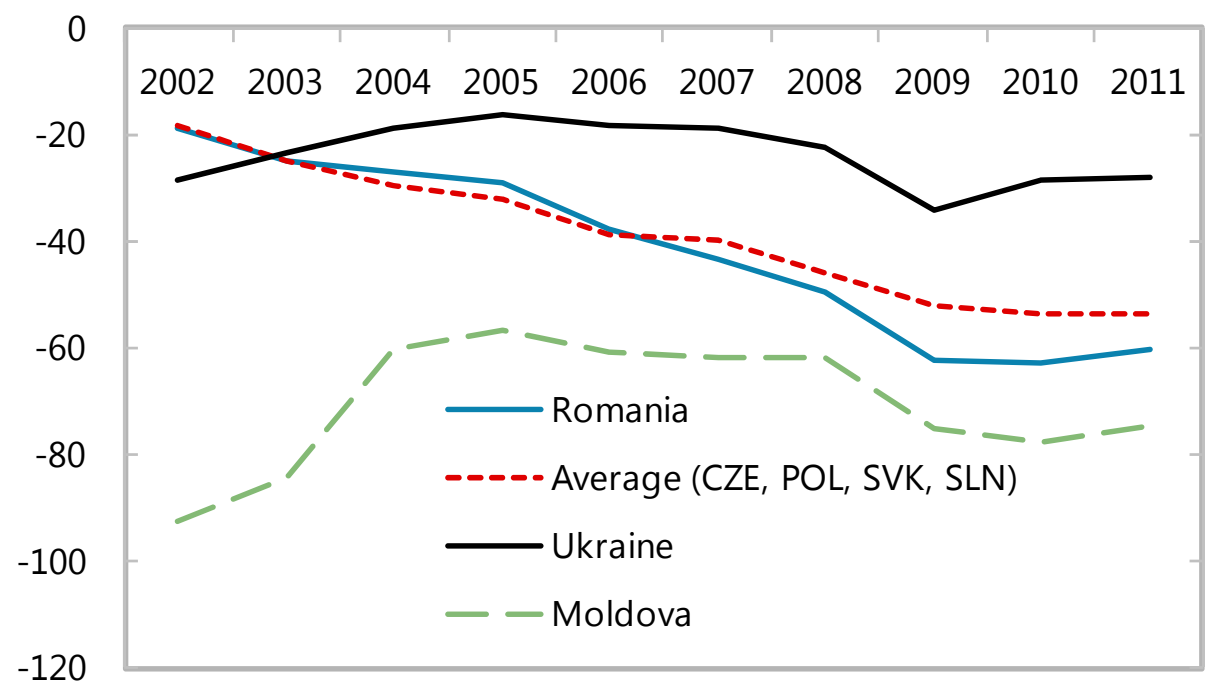

0

Sources: Moldovan authorities; and IMF staff calculations.

\section{G. Conclusions and Policy Recommendations}

33. Since 2009, Moldova's authorities have implemented a number of ambitious structural reforms in the context of the IMF-supported program. The reforms of the tax system, education, pension and social assistance, the energy sector, external trade, and 
business regulation have increased Moldova international competitiveness and attractiveness to foreign investors. As a result, Moldova advanced by 18 positions to rank 81 in the 2011/12 WB "Doing Business" survey, claiming second place in the list of top reformers. The reforms also sustained strong GDP expansion of $6 \frac{1}{2}-7$ percent in $2010-11$ and raised potential growth.

34. Contrary to popular belief, Moldova has built a good track record in attracting foreign investments. The accumulated stock of FDI reached about half of the country's GDP in 2011, surpassing on this indicator many other economies in the region. Trade integration with EU and CIS countries, improvements in the business climate, privatization, and healthy growth prospects are the factors that would further improve Moldova's potential for attracting FDI.

\section{In the past, foreign investors coming to Moldova focused on accessing the} domestic market, but this is already changing. More than three-quarters of the accumulated FDI stock comprise investments in sectors producing non-tradable goods and services. This is broadly in line with the structure of economy focused on serving the domestic demand rather than producing exports. An important shift in this pattern came in 2011, when the share of FDI inflows in the key sectors producing tradables - agriculture and industry—increased considerably.

\section{After the significant appreciation in 2011, Moldova's currency has become} moderately overvalued. Both CPI-based and ULC-based measures of the REER went through considerable adjustment in 2009-10, but in 2011 the CPI-based REER appreciated by about 10 percent. According to all three estimation methods, the leu is slightly above its fundamental equilibrium value, with overvaluation generally in the 5-15 percent range. Various methods suggest that a current account deficit of about 5-7 percent of GDP leads to a sustainable external position over the long term. As the current account deficit in 2011 reached $12 \frac{1}{2}$ percent of GDP, this underscores the need to boost external competitiveness.

37. To gain an edge in external competitiveness and stimulate new investments, it is critically important to persevere with the structural reform agenda. The international competitiveness rankings and surveys highlighted the factors that investors see as impediments to business growth. According to the WEF GCI surveys, policy instability and governance issues have become the most important hurdles to the business activity. The World Bank's "Doing Business" survey emphasized obstacles that the businesses face in dealing with construction permits, trading across borders, and protecting investments. These obstacles to investment and growth should be addressed as a matter of priority. 


\section{Appendix II.I. Methodology of Calculating FDI Performance and Potential INDICES}

\section{The Inward FDI Performance Index}

The Inward FDI Performance Index ranks countries by the FDI they receive relative to their economic size. It is the ratio of a country's share in global FDI inflows to its share in global GDP.

A value greater than one indicates that the country receives more FDI than its relative economic size, a value below one that it receives less (a negative value means that foreign investors disinvest in that period).

The index thus captures the influence on FDI of factors other than market size, assuming that, other things being equal, size is the "baseline" for attracting investment. These other factors can be diverse, ranging from the business climate, economic and political stability, the presence of natural resources, infrastructure, skills and technologies, to opportunities for participating in privatization or the effectiveness of FDI promotion.

$$
I N D_{i}=\frac{F D I_{i} / F D I_{w}}{G D P_{i} / G D P_{w}}
$$

Where,

$\mathrm{IND}_{\mathrm{i}}=$ The Inward FDI Performance Index of the $i^{\text {th }}$ country

$\mathrm{FDI}_{\mathrm{i}}=$ The FDI inflows in the $i^{\text {th }}$ country

$\mathrm{FDI}_{\mathrm{w}}=$ World FDI inflows

$\mathrm{GDP}_{\mathrm{i}}=G D P$ in the $i^{\text {th }}$ country

$\mathrm{GDP}_{\mathrm{w}}=$ World GDP

\section{The Inward FDI Potential Index}

The Inward FDI Potential Index captures several factors (apart from market size) expected to affect an economy's attractiveness to foreign investors. It is an average of the values (normalized to yield a score between zero, for the lowest scoring country, to one, for the highest) of 12 variables (no weights are attached in the absence of a priori reasons to select particular weights):

- GDP per capita, an indicator of the sophistication and breadth of local demand (and of several other factors), with the expectation that higher income economies attract relatively more FDI geared to innovative and differentiated products and services.

- $\quad$ The rate of GDP growth over the previous 10 years, a proxy for expected economic growth. 
- The share of exports in GDP, to capture openness and competitiveness.

- As an indicator of modern information and communication infrastructure, the average number of telephone lines per 1,000 inhabitants and mobile telephones per 1,000 inhabitants.

- Commercial energy use per capita, for the availability of traditional infrastructure.

- The share of R\&D spending in GDP, to capture local technological capabilities.

- The share of tertiary students in the population, indicating the availability of highlevel skills.

- Country risk, a composite indicator capturing macroeconomic and other factors that affect the risk perception of investors. The variable is measured in such a way that high values indicate less risk.

- The market share in world exports of natural resources, to proxy for the availability of resources for extractive FDI.

- The market share in world imports of parts and components for automobiles and electronic products, to capture participation in the leading TNC integrated production systems (WIR02).

- The market share in world exports of services, to seize the importance of FDI in the services sector that accounts for some two thirds of world FDI.

- The share of world inward FDI stock, a broad indicator of the attractiveness and absorptive capacity for FDI, and the investment climate. 


\section{REFERENCES}

Arbatli, Elif, 2011: "Economic Policies and FDI Inflows to Emerging Market Economies", IMF Working Paper WP/11/192 (Washington: International Monetary Fund).

Atoyan, Ruben, Albert Jaeger, Dustin Smith, 2012: "Pre-Crisis Absorption Booms and Capital Flows in Emerging Europe: Did Countercyclical Fiscal Policy Work?", IMF Working Paper (forthcoming) (Washington: International Monetary Fund).

Dabla-Norris, Era, et al., 2010: "FDI Flows to Low-Income Countries: Global Drivers and Growth Implications”, IMF Working Paper WP/10/132 (Washington: International Monetary Fund).

Demekas, Dimitri, et al., 2005: "Foreign Direct Investment in Southeastern Europe: How (and How Much) Can Policies Help?", IMF Working Paper WP/05/110 (Washington: International Monetary Fund).

Gorbanyov, Michael, et al., 2010: “Republic of Moldova: Selected Issues Paper,” IMF Country Report No. 10/232 (Washington: International Monetary Fund).

Kinda, Tidiane, 2010: "Investment Climate and FDI in Developing Countries: Firm-Level Evidence", World Development Vol. 38, No. 4, pp. 498-513, 2010.

Kinda, Tidiane, 2012:" On the Drivers of FDI and Portfolio Investment: A Simultaneous Equations Approach", International Economic Journal, 26(1): 1-22.

Kudina, Alina, and Malgorzata Jakubiak, 2011: "The Motives and Impediments to FDI in the CIS”, Dabrowski and Maliszewska, EU Eastern Neighborhood, Chapter 5 (SpringerVerlag Berlin Heidelberg 2011).

Vitek, Francis, 2009: "An Assessment of External Price Competitiveness for Mozambique", IMF Working Paper WP/09/165 (Washington: International Monetary Fund). 


\section{A SPILLOVER REPORT ${ }^{1}$}

\section{A. Introduction}

1. The recent global financial crisis has shown how vulnerable Moldova's small open economy is to external shocks (Figure 1). GDP fell by 6 percent in 2009 in the wake of the crisis, as remittances and exports plummeted and net capital inflows nearly dried up. In light of the persistent volatility in the world economy, it is therefore essential to understand how external shocks could affect Moldova's economy in the future.

2. This paper assesses the channels, notably trade, remittances, and capital flows, through which external economic developments affect Moldova, and provides a quantitative summary of these spillovers by means of a VAR analysis. The trade and remittances channels are examined in Section II, followed by the financial channels in Section III. Section V concludes.

\section{B. Trade and Remittances Channels}

3. Moldova's economy relies heavily on trade and remittances. In 2011, exports of goods and services accounted for about 45 percent of GDP while imports reached 86 percent of GDP. Close to 40 percent of exports are destined to CIS countries, with Russia receiving the lion share, and about half are shipped to the EU, especially Romania, Germany and Italy, in that order (Figure 2). The same countries, plus Turkey and China, are the main sources of imports to Moldova. ${ }^{2}$ With a large part of its labor force working abroad and a considerable diaspora, Moldova is one of the largest recipients of personal transfers (remittances and workers' compensation) in the world relative to GDP. At end-2011 they amounted to almost a quarter of GDP, and more than half of them originated from Russia (Figure 3). Judging from the currency composition of the flow of transfers and anecdotal evidence, the EU, notably Italy, likely accounts for the largest share of remittances outside Russia.

\section{Moreover, trade and remittances are quite sensitive to external economic} conditions. During the 2009 crisis, remittances and exports dropped by 30 percent and 20 percent respectively, while imports fell by over 30 percent. Export elasticity over the last decade is estimated to be close to 1 with respect to trade-weighted partner country GDP and at -1.6 with respect to relative export prices (Appendix 1, Table 1). Interestingly, changes in the real exchange rate seem to have little effect on export performance in the short

\footnotetext{
${ }^{1}$ Prepared by Svitlana Maslova and Gabriel Srour.

${ }^{2}$ Trade with Turkey, and especially imports from China, have shot up in the last few years, possibly reflecting a substantial increase in re-exports.
} 
run. ${ }^{3}$ Imports react vigorously to domestic demand changes (elasticity 1.8), but are less sensitive to price and exchange rate changes possibly due to a relatively large share of energy imports (estimated elasticities of -1 and -0.5 , respectively; Appendix 1, Table). The regression analysis also points at high sensitivity of the migrant workers' personal transfers (remittances and compensation) to economic developments in foreign countries: compensation elasticity with respect to foreign GDP growth is estimated at nearly 4 (Appendix 1, Table 3).

5. It is noteworthy that the drop in trade in $\mathbf{2 0 0 9}$ was more or less even across the three regions (CIS, EU, and the rest of the world (ROW)), despite a steeper contraction of GDP in the CIS countries than in the EU. ${ }^{4}$ The sharper real exchange rate (RER) depreciation against CIS countries may partially explain this result. Similarly, remittances originating from Russia surprisingly fell more modestly despite the fact that Russia's economy contracted almost twice as much as the EU. It is therefore possible that exports and remittances destined to the EU are more elastic than those destined to Table 1. Moldova: External Trade by Region, 2009 CIS countries perhaps reflecting the composition of exports and the nature of migrants' work in different countries. ${ }^{5}$ In any event, economic developments in the CIS countries, especially Russia, and their impact on trade and remittances with that region, could significantly magnify or dampen a shock.

\begin{tabular}{lcccc}
\hline \multicolumn{5}{c}{ (Year-on-year, percent) } \\
\hline Russia & Exports & Imports & GDP & RER 1/ \\
CIS & -8.7 & -43.8 & -7.8 & 23.5 \\
EU & -19.9 & -34.3 & -6.4 & 23.5 \\
ROW & -18.5 & -32.5 & -4.2 & 12.8 \\
World & -18.9 & -32.3 & 0.6 & 9.3 \\
& -19.1 & -33.1 & -0.7 & \\
\hline
\end{tabular}

Sources: Ministry of Trade; World Economic Outlook; and IMF staff estimates.

1/ An increase implies depreciation of the leu vs. counterpart. The real exchange rate with CIS is approximated by that with Russia.

\footnotetext{
${ }^{3}$ This result could be consistent with exporters selling at international prices, which are fixed in foreign currency. In the short run, REER changes might then affect losses/profits but not volumes as long as these are fixed in longer-term contracts. Yet, in the long term, REER changes might well affect export volumes. For instance, REER depreciation allows easier settlement of exporters' financial obligations. If sustained, this would encourage production expansion over time.

${ }^{4}$ However, this hides strong heterogeneity across countries. For instance exports to Ukraine dropped more than 40 percent in 2009, while those to Germany actually increased.

${ }^{5}$ Another factor could be the proximity (geographic and cultural) of Russia whereby it is easier to adjust and redirect some exports and/or workers to Russia than to Europe. However this seems to be contradicted by the drop of almost 30 percent in exports to Romania.
} 
Figure 1. Moldova: Economic Developments, 2000-11
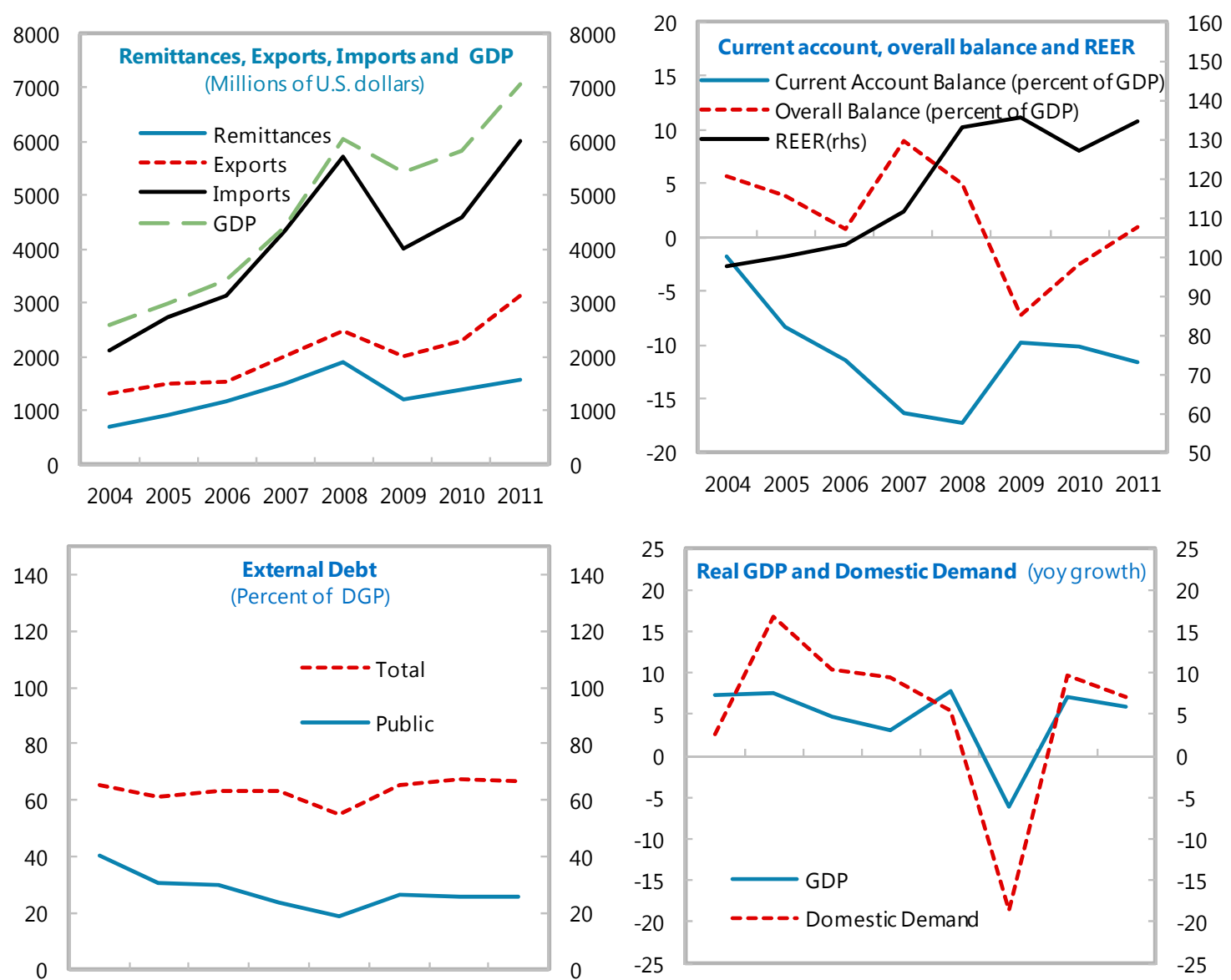

25

20

20042005200620072008200920102011

20042005200620072008200920102011
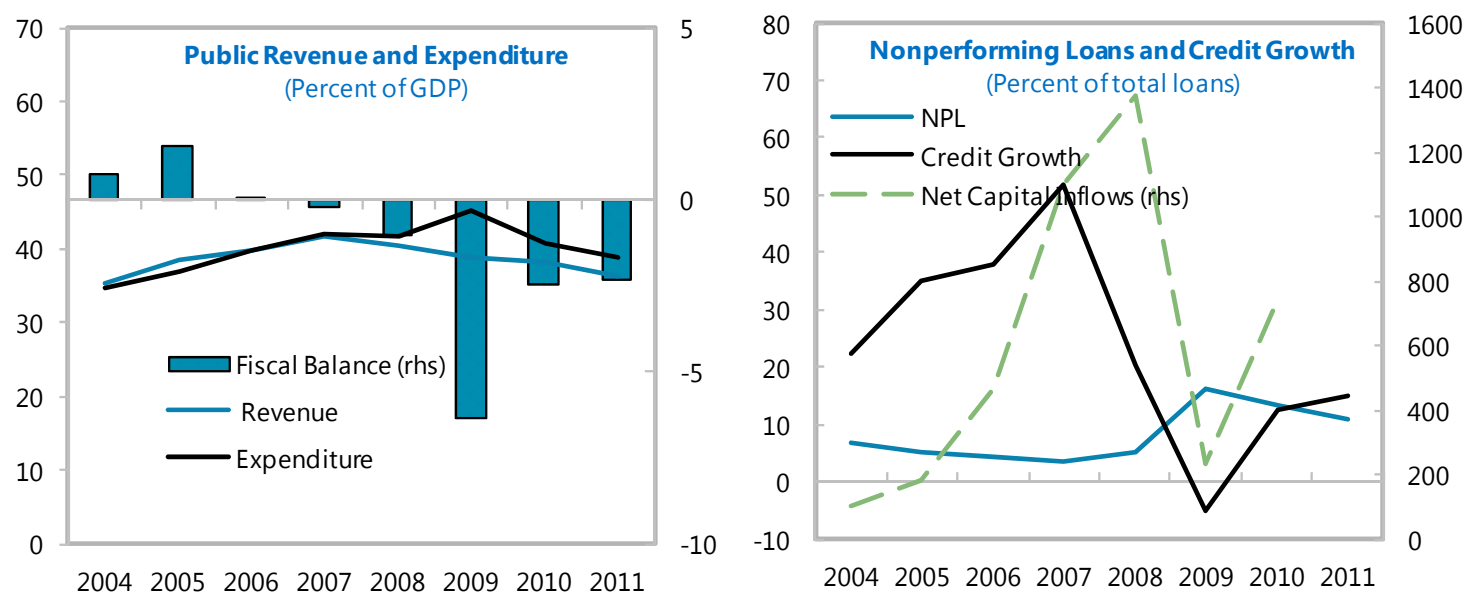

Sources: Moldovan authorities; Haver; and IMF staff estimates. 
Figure 2. Moldova: Export and Import Shares, 2011

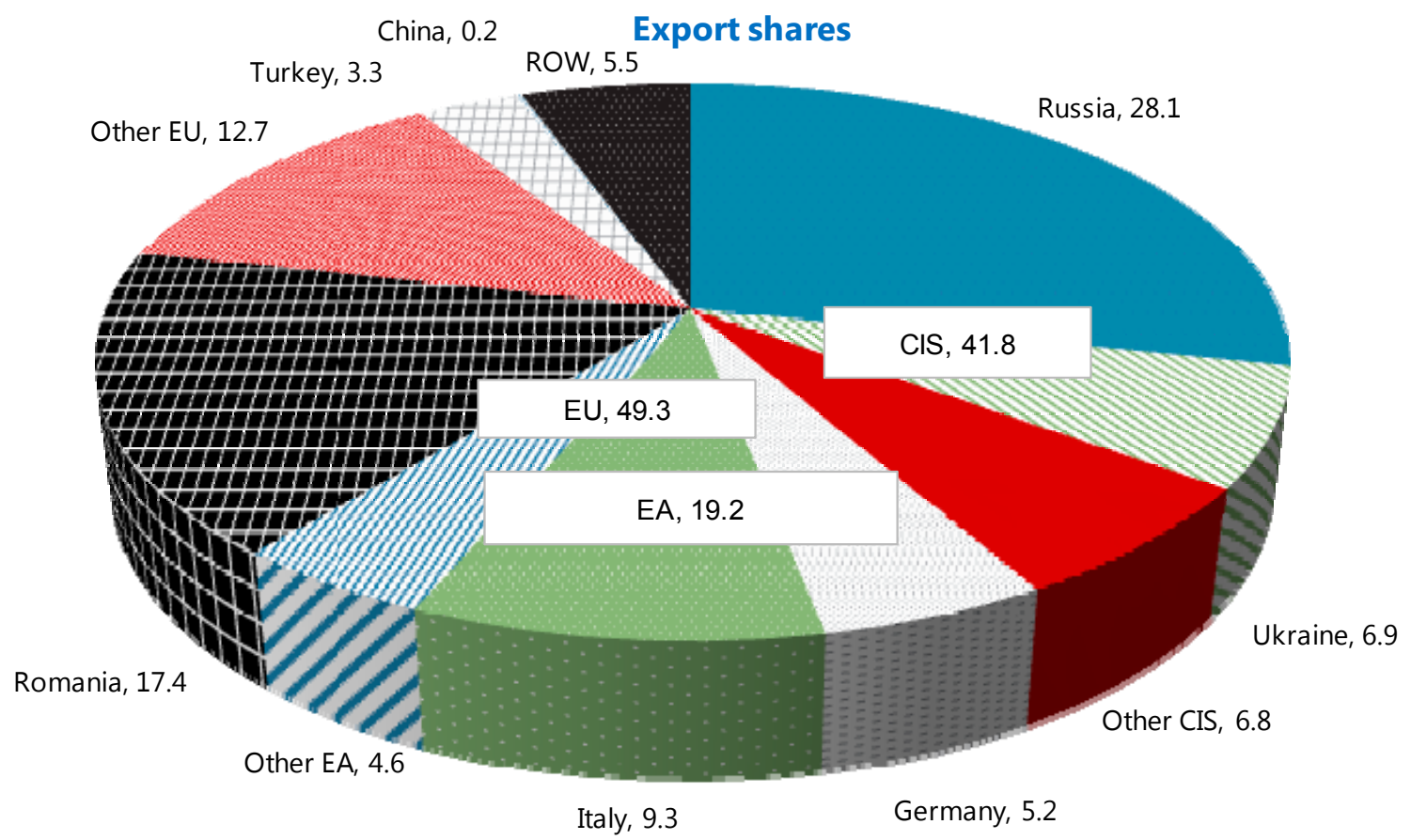

Import shares

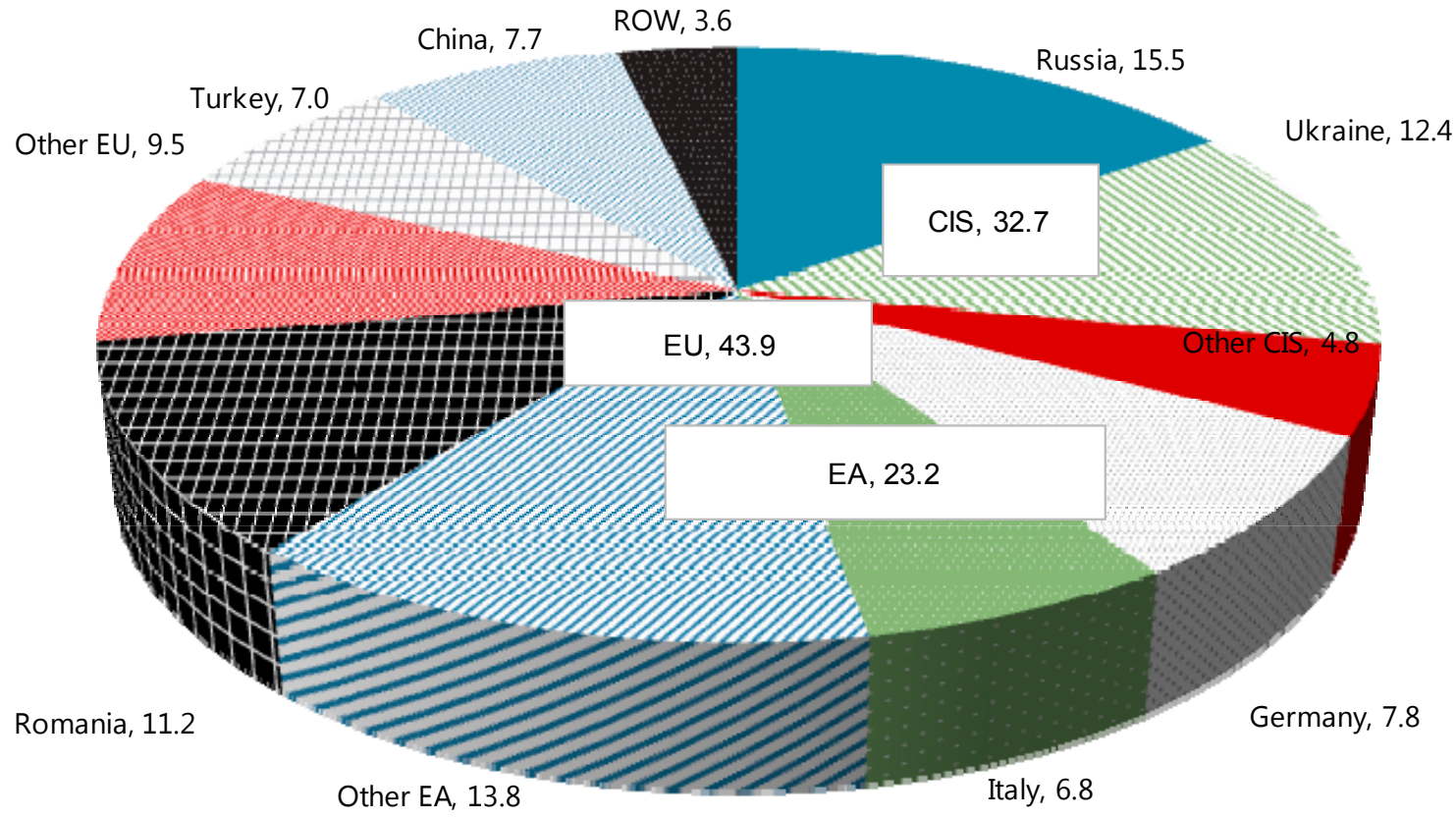

Sources: Ministry of Trade; and IMF staff estimates. 
6. Thus an external economic downturn is likely to have significant repercussions on Moldova's growth and incomes through exports and remittances. Exports and remittances have been steadily rising prior to the crisis, reflecting greater regional integration and workers' migration from Moldova, and one can surmise that they will remain highly sensitive to downturns in the host countries. A regional shock, say in Europe, can also spill over into Moldova indirectly through its effects on the CIS countries, especially Russia. By the same token, these countries can mitigate the effects of the shock if for instance commodity prices sustain their economies.

Figure 3. Worker Remittances, 2000-10 Quantitative estimates (Appendix II) suggest that in the case of a broad downturn, imports are likely to fall significantly more than exports, due to the overall larger impact that the shock will have on income in Moldova than on its trading partners, the relatively large income elasticity of imports, and the likely depreciation of the exchange rate following (Millions of U.S. dollars)

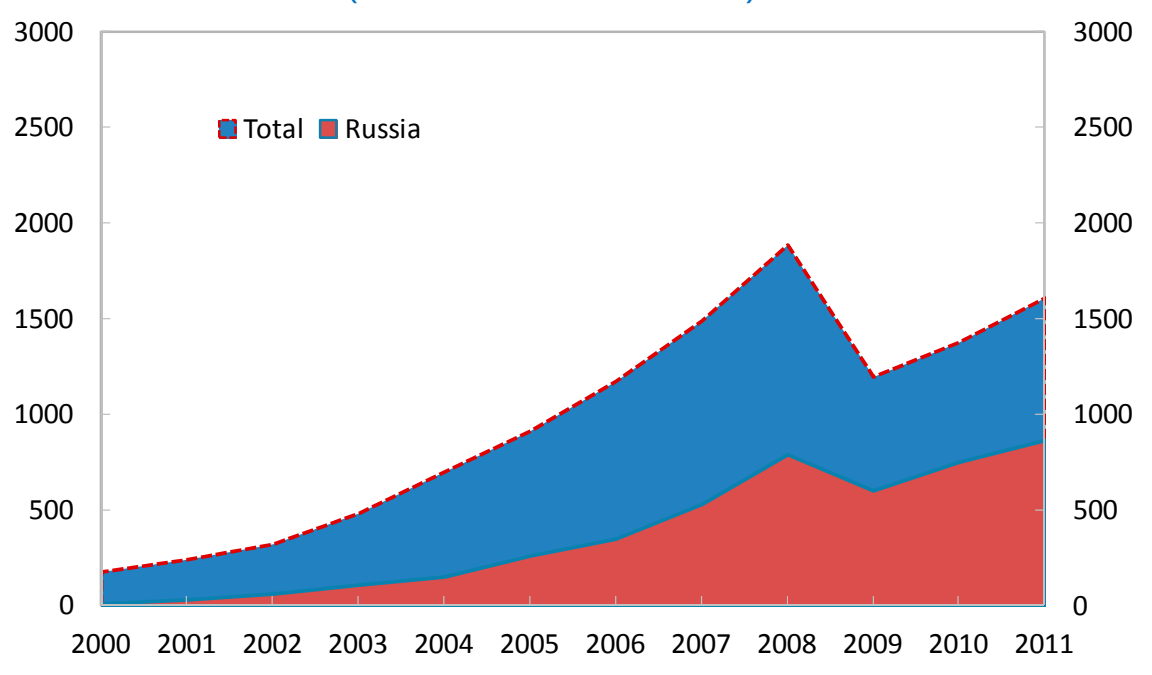
such a shock.

\section{Capital and Financial Spillovers}

\section{There are multiple financial channels through which external developments} could in principle impact Moldova: (a) Moldova could take losses on foreign assets it holds; (b) foreign financial institutions could reduce their exposure to Moldova, forcing the local financial sector in turn to deleverage; (c) other capital inflows, including foreign direct investment, could dry up and outflows accelerate; and (d) currency mismatches could cause losses for unhedged entities in the event of large devaluations of the leu.

\section{Tables 2 and 3 sum up Moldova's foreign position bank-by-bank and the buffers} available to each bank as of end-September 2011. It is apparent that all banks run relatively balanced overall foreign exchange positions, albeit a few borrow abroad to finance domestic lending in foreign exchange, and others finance foreign operations with foreign exchange borrowed domestically (more on this below). 
Table 2. Moldova: Foreign Position, Sept-2011 (percent of bank's total assets)

\begin{tabular}{|c|c|c|c|c|c|c|c|c|c|c|}
\hline Bank & $\begin{array}{c}\text { Total } \\
\text { FX } \\
\text { assets }\end{array}$ & $\begin{array}{c}\text { Total } \\
\text { FX } \\
\text { liabilities } \\
\end{array}$ & $\begin{array}{c}\text { Overall } \\
\text { FX } \\
\text { position }\end{array}$ & $\begin{array}{c}\text { Domestic } \\
\text { FX } \\
\text { assets } \\
\end{array}$ & $\begin{array}{c}\text { Domestic } \\
\text { FX } \\
\text { liabilities }\end{array}$ & $\begin{array}{c}\text { Domestic } \\
\text { FX } \\
\text { position }\end{array}$ & $\begin{array}{c}\text { Foreign } \\
\text { assets }\end{array}$ & $\begin{array}{c}\text { Foreign } \\
\text { liabilities }\end{array}$ & $\begin{array}{l}\text { Liabilities } \\
\text { to IFIs }\end{array}$ & $\begin{array}{c}\text { Net } \\
\text { foreign } \\
\text { position }\end{array}$ \\
\hline 1 & 33.7 & 32.4 & 1.3 & 29.7 & 32.0 & -2.3 & 3.9 & 0.3 & 0.0 & 3.6 \\
\hline 2 & 64.7 & 64.8 & -0.1 & 49.9 & 12.4 & 37.5 & 14.8 & 52.4 & 9.7 & -37.6 \\
\hline 3 & 37.8 & 36.3 & 1.6 & 36.1 & 35.9 & 0.2 & 1.8 & 0.4 & 0.0 & 1.3 \\
\hline 4 & 27.1 & 28.7 & -1.6 & 19.7 & 23.1 & -3.4 & 7.4 & 5.6 & 0.0 & 1.8 \\
\hline 5 & 45.6 & 46.0 & -0.4 & 40.5 & 41.5 & -1.0 & 5.2 & 4.5 & 0.0 & 0.6 \\
\hline 6 & 54.3 & 53.8 & 0.6 & 49.8 & 26.3 & 23.5 & 4.5 & 27.5 & 13.5 & -22.9 \\
\hline 7 & 54.6 & 53.4 & 1.2 & 52.3 & 15.3 & 37.0 & 2.3 & 38.1 & 3.1 & -35.8 \\
\hline 8 & 37.3 & 37.7 & -0.4 & 20.7 & 35.3 & -14.6 & 16.6 & 2.4 & 0.0 & 14.2 \\
\hline 9 & 41.8 & 40.8 & 1.0 & 36.9 & 31.4 & 5.5 & 4.8 & 9.4 & 5.2 & -4.6 \\
\hline 10 & 47.0 & 43.3 & 3.7 & 44.2 & 33.9 & 10.3 & 2.8 & 9.4 & 5.5 & -6.6 \\
\hline 11 & 37.9 & 37.0 & 0.9 & 36.4 & 30.4 & 6.0 & 1.5 & 6.6 & 3.5 & -5.2 \\
\hline 12 & 41.1 & 42.1 & -1.0 & 33.4 & 32.0 & 1.3 & 7.7 & 10.1 & 0.0 & -2.3 \\
\hline 13 & 42.5 & 41.4 & 1.1 & 34.9 & 25.7 & 9.2 & 7.6 & 15.7 & 9.1 & -8.2 \\
\hline 14 & 27.7 & 28.5 & -0.7 & 19.3 & 26.5 & -7.2 & 8.4 & 2.0 & 0.0 & 6.5 \\
\hline 15 & 33.0 & 38.7 & -5.7 & 30.4 & 20.9 & 9.5 & 2.6 & 17.9 & 0.0 & -15.3 \\
\hline Total & 43.1 & 42.2 & 0.9 & 38.2 & 31.3 & 6.9 & 4.9 & 11.0 & 4.1 & -6.1 \\
\hline
\end{tabular}

Sources: Moldovan authorities and IMF staff estimates

Table 3. Moldova: Financial Soundness Indicators, Sep-2011

(Percent of bank's total assets)

\begin{tabular}{rrrr}
\hline \multicolumn{5}{c}{ Liquid $F X$} \\
Bank & Liquid assets & assets & \multicolumn{1}{c}{ CAR } \\
\hline 1 & 31.3 & 7.3 & 27.9 \\
2 & 23.2 & 3.1 & 17.6 \\
3 & 31.8 & 8.3 & 38.6 \\
4 & 35.4 & 5.5 & 23.4 \\
5 & 37.7 & 8.1 & 23.2 \\
6 & 24.1 & 6.9 & 33.3 \\
7 & 30.7 & 4.5 & 35.7 \\
8 & 48.6 & 9.8 & 90.0 \\
9 & 30.4 & 5.7 & 25.0 \\
10 & 28.4 & 7.5 & 23.1 \\
11 & 41.9 & 12.3 & 49.7 \\
12 & 39.8 & 8.9 & 84.8 \\
13 & 24.1 & 5.6 & 24.5 \\
14 & 47.1 & 7.0 & 101.9 \\
15 & 21.4 & 15.0 & 39.7 \\
Total & 31.7 & 7.2 & 28.5 \\
\hline
\end{tabular}

Sources: Moldovan authorities; and IMF staff estimates.

1/ Percent of total assets in the banking sector 


\section{Exposure to Asset Losses}

\section{The aggregate exposure of Moldova's banking system to losses from foreign} assets is relatively small (Figure 4 and Table 4). The risk of asset losses stems from two possible sources: (i) re-pricing of debt securities or sovereign defaults; and (ii) counterparty risk in foreign bank partners. However, exposure to both risks appears to be small, as total foreign assets held by the banking system make up only about 5 percent of total assets (about 3 percent of GDP), more than half of which are held in nostro accounts and less than a third in long-term instruments, including a negligible amount in sovereign bonds (Table 4). About two-third of the foreign assets are held in the euro area, but they appear to be well diversified across countries.

Figure 4. Moldova: Asset by Destinaton, Sept-2011
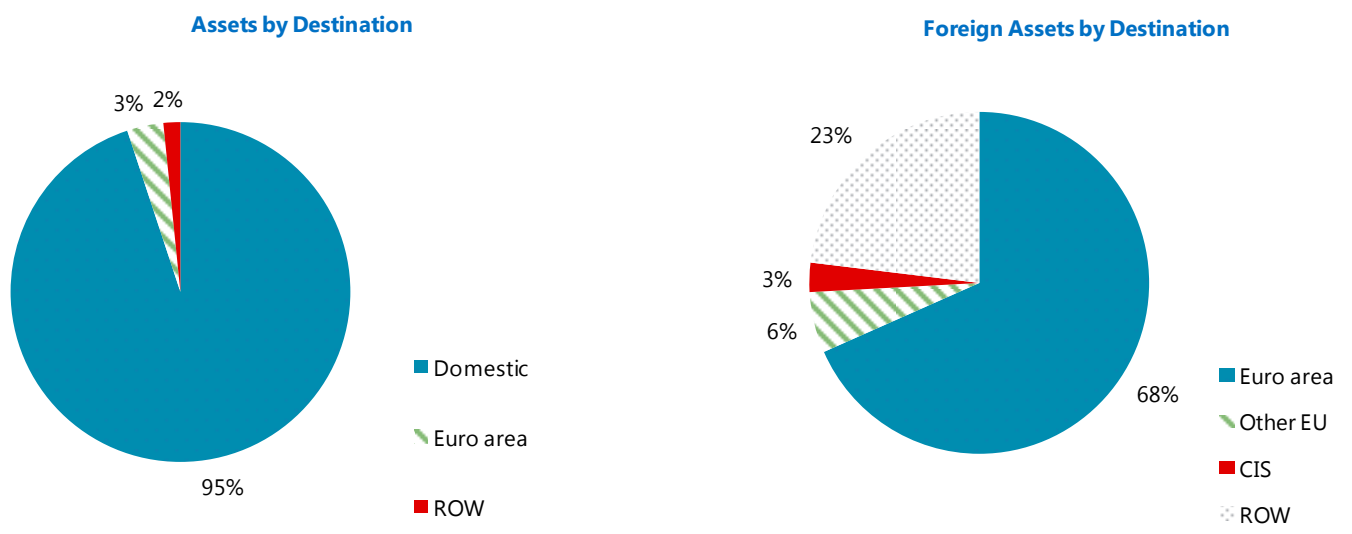

Sources: Central Bank of Moldova; and IMF staff estimates.

Table 4. Moldova: Banking System Foreign Position, Sept-2011

(Percent of total assets)

\begin{tabular}{lrrrrrr}
\hline & Total & \multicolumn{1}{c}{ EA } & EU & CIS & IFIs & Other \\
\hline Foreign assets & 5.2 & 3.5 & 3.8 & 0.1 & 0.0 & 1.2 \\
$\quad$ Nostro accounts opened abroad & 2.8 & 1.6 & 1.7 & 0.1 & 0.0 & 0.9 \\
$\quad$ Placements abroad of authorized & & & & & & \\
$\quad$ banks from Moldova & 1.3 & 1.1 & 1.2 & 0.0 & 0.0 & 0.0 \\
$\quad$ Overnight placements and credits & 0.9 & 0.6 & 0.6 & 0.0 & 0.0 & 0.2 \\
$\quad$ Sovereign bonds & 0.3 & 0.2 & 0.3 & 0.0 & 0.0 & 0.0 \\
Foreign liabilities & 10.1 & 5.4 & 5.4 & 0.2 & 4.1 & 0.5 \\
$\quad$ Loro accounts of foreign banks & 0.0 & 0.0 & 0.0 & 0.0 & 0.0 & 0.0 \\
$\quad$ Deposits & 1.1 & 0.7 & 0.7 & 0.1 & 0.0 & 0.4 \\
$\quad$ Loans from financial entities & 9.0 & 4.7 & 4.7 & 0.1 & 4.1 & 0.1 \\
Net foreign assets & -4.9 & -1.9 & -1.6 & 0.0 & 0.0 & -3.3 \\
\hline
\end{tabular}

Sources: Moldovan authorities; and IMF staff estimates. 
10. This limited exposure of the banking system as a whole is shared by individual banks, except perhaps for Banks 2, 8, and to a lesser extent 14, which hold respectively about 15, 17, and 8.5 percent of their total assets as foreign assets.

- $\quad$ Bank 2 is a subsidiary of a foreign bank, and its FX exposure is largely financed by the parent bank. The impact of asset losses on this bank is therefore better viewed in the context of potential deleveraging of foreign banks from Moldova (Section below).

- In contrast, bank 8's foreign holdings are mostly financed domestically, with a NFA equal to about 14 percent of bank's total assets (covered by its domestic foreigncurrency position) (Table 2). One-third of its foreign assets are held in nostro accounts and overnight deposits, while two-third are in other placements. However, the bank's very strong buffers (Table 3 ) both in capital and liquidity suggest that potential losses could be absorbed relatively easily.

- $\quad$ The case of the foreign-owned Bank 14 is very similar to Bank 8, except that with a NFA of about 6.5 percent of total assets, almost all of its foreign assets held in nostro accounts, and comparable buffers, its exposure appears even more manageable.

\section{Exposure to Deleveraging}

\section{Overall, the banking sector in Moldova is relatively insulated from potential} deleveraging by foreign banks. Foreign bank exposure to Moldova has been rapidly increasing since the middle of the last decade, but it remains relatively limited. Foreign bank subsidiaries in Moldova account for about a fifth of total assets in the banking sector. Foreign liabilities of Moldova's banks at end-2011 amount to about 11 percent of the banks' total assets (or $5 \frac{1}{2}$ percent of GDP), with more than a third owed to international financial institutions (IFIs) and the rest mostly owed to the EU (Figures 5, $6)$. The overall NFA position of the banking sector excluding IFIs comes short by only about 2 percent of total assets.

Figure 5. EU banks claims on Moldova (Millions of U.S. dollars)

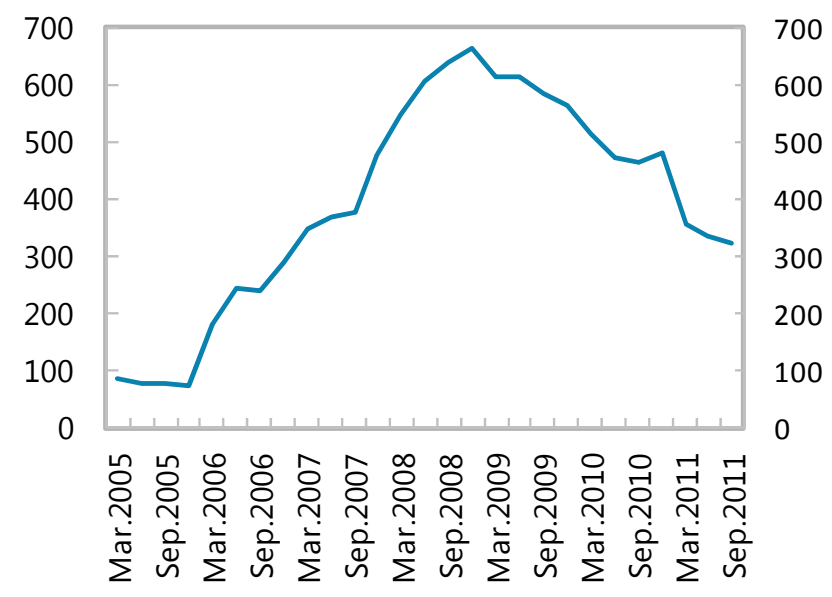

Source: BIS, locational unconsolidated data. 


\section{Deleveraging by foreign banks should therefore have a limited impact on the} domestic banking sector overall. A 25 percent reduction in the exposure of foreign banks (other than IFIs) to Moldova's banking sector amounts to only 2 percent of the banking sector total assets and should therefore not place significant stress on the system. Such a potential surge in demand for foreign exchange should be manageable on impact given the amount of liquidity (31 percent of total assets) held in the banking sector, the amount of liquidity in foreign currency ( 7 percent of total assets), and the NBM reserves (about 50 percent of total assets). Over the longer term the banks could also draw down their foreign assets, thus taking pressure off domestic credit.

Figure 6. Moldova: Banks Foreign Liabilities by Origin, Sept-2011
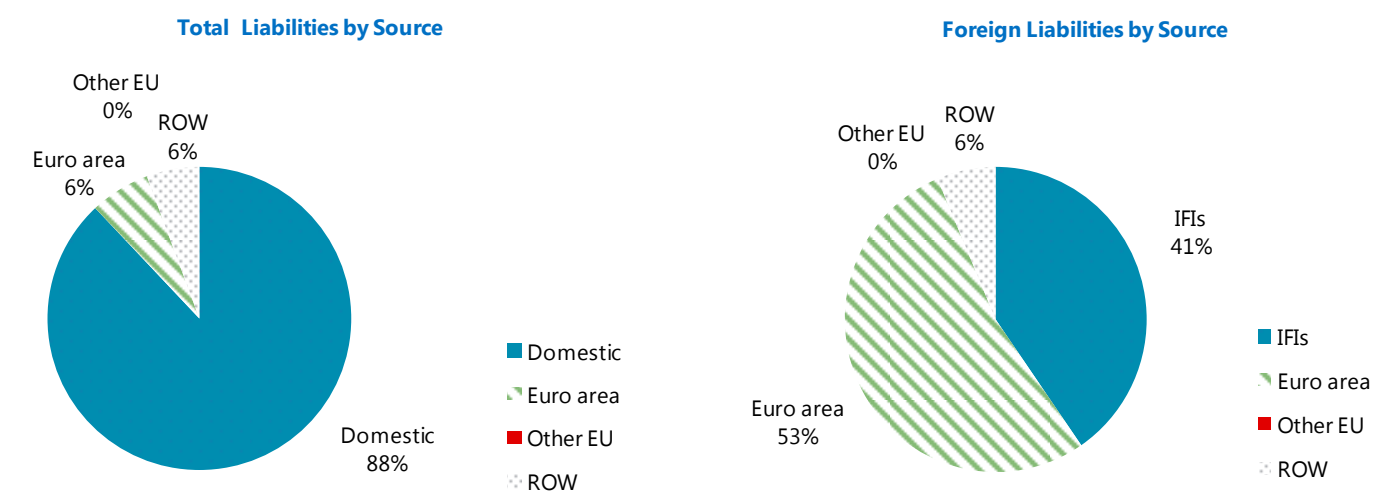

Sources: Central Bank of Moldova; and IMF staffestimates.

\section{However, three foreign-owned banks-Banks 2, 6, and 7-accounting for about} 14 percent of total assets in the banking system, hold almost half of total foreign

liabilities (Table 5). These banks are clearly more exposed to deleveraging than the average position, but the risks are moderate.

Table 5. Moldova: Foreign Liabilities, Sept-2011

(percent of assets)

\begin{tabular}{|c|c|c|c|c|c|c|c|}
\hline Bank & $\begin{array}{c}\text { Foreign } \\
\text { Liabilities }\end{array}$ & $\begin{array}{c}\text { Liabilities to } \\
\text { IFIs }\end{array}$ & $\begin{array}{l}\text { Liabilities to } \\
\text { parent bank }\end{array}$ & $\begin{array}{l}\text { Foreign } \\
\text { assets }\end{array}$ & $\begin{array}{c}\text { Net foreign } \\
\text { liabilities ex IFIs }\end{array}$ & $\begin{array}{l}\text { Liquid } \\
\text { assets }\end{array}$ & $\begin{array}{l}\text { Liquid FX } \\
\text { assets }\end{array}$ \\
\hline 2 & 52.4 & 9.7 & 39.3 & 14.8 & 27.9 & 21.5 & 3.1 \\
\hline 6 & 27.5 & 13.5 & 9.7 & 4.5 & 9.4 & 27.0 & 6.9 \\
\hline 7 & 38.1 & 3.1 & 14.0 & 2.3 & 32.7 & 33.4 & 4.5 \\
\hline
\end{tabular}

Sources: Moldovan authorities and IMF staff estimates

- In the case of Bank 2, the exposure is mitigated by the fact that the foreign liabilities are mostly owed to the parent bank and IFIs. Nevertheless a moderate reduction of foreign exposure could cause some stress - a 10 percent drawdown in foreign 
financing (excluding IFIs) amounts to about 4 percent of the bank's total assets and 17 percent of its liquid assets.

- $\quad$ For Bank 6, the NFA position excluding IFIs is short by less than 10 percent of total assets, less than half the amount of liquid assets of the bank, and most of it financed by the parent bank. Thus the risk of deleveraging appears manageable for this bank.

- $\quad$ For Bank 7, the absolute exposure level is lower than Bank 2, and the liquidity buffer is higher. However, about 50 percent of the foreign liabilities are deposits originating from EA, and therefore could be at a higher risk of deleveraging.

\section{Other Investment Flows}

14. Moldova is highly exposed to sudden stops in capital inflows. After expanding strongly in the period leading to the financial crisis, capital inflows contracted sharply in 2009, prompting recourse to exceptional external financing and a strong correction in the current account balance.

\section{Trade credit and private loans represent different spillover channels. Being} largely used to finance imports, trade credit is highly correlated with import flows. Thus, if domestic demand in the country declines, depressing imports, trade credit flows moderate. Supply factors may play a role as well, as the decrease in banking sector's liquidity in foreign countries or deterioration in banking confidence could lead to reduced availability of trade financing. That said, initiatives to support trade financing adopted by the World Bank and other international organizations at the time of the 2008-09 crisis could prop credits somewhat. In Moldova, trade credits were rather resilient in 2008-09 with rollover ratios moderating only to 115 percent in 2009 compared to 136 percent on average in 2003-08.

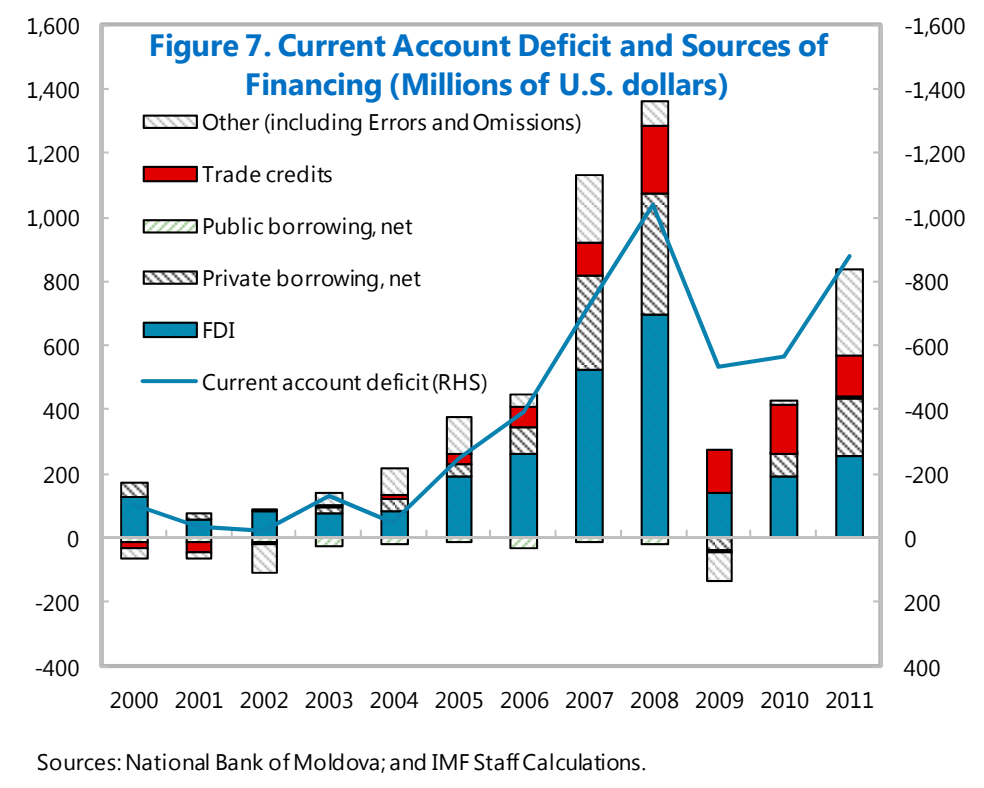

16. Private borrowing has been relatively resilient in Moldova. In 2009 incoming private loans, though smaller than before the crisis, were sufficient to cover repayments coming due. Such resilience is probably due to the fact that, like in other CEE countries, private loans are mainly extended to foreign-owned companies from their parents abroad. 
That said, short-term borrowing was quite significantly affected with rollover ratio at a meager 33 percent in 2009. The recent debt data does not suggest problems with borrowing abroad for Moldovan companies. However, deterioration in the economic conditions in Moldova's major economic partnerswhere the companies with subsidiaries in Moldova are

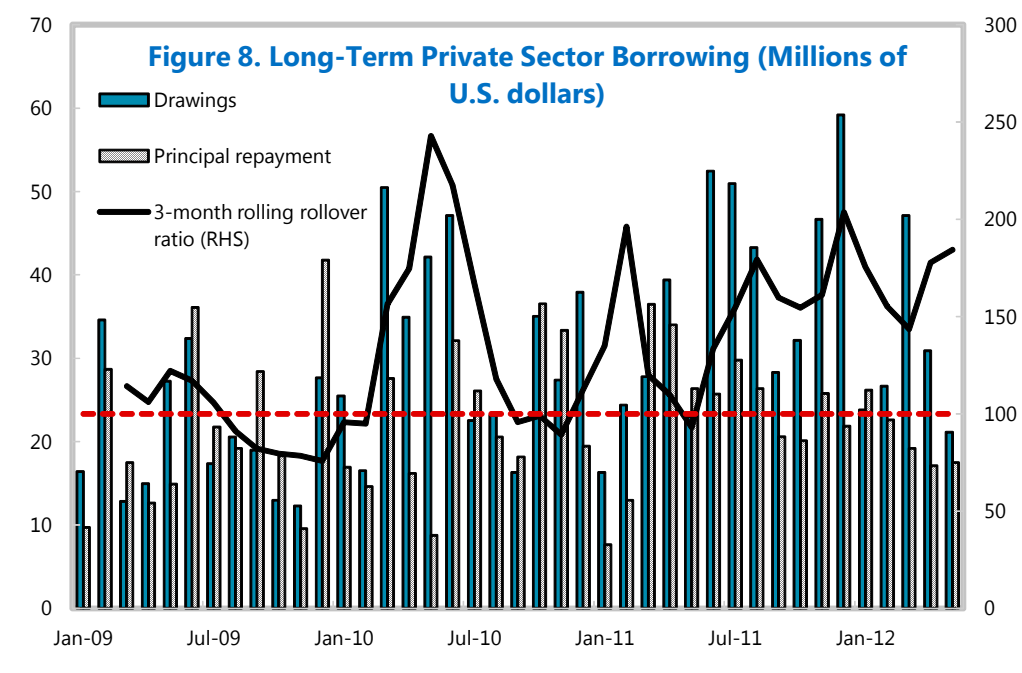

Sources: National Bank of Moldova; and IMF Staff Calculations.

located - could lead to some decline in the available external financing for the private sector.

17. Interestingly, public borrowing partially offset the decline in private capital inflows during the 2008-09 crisis. The rollover ratio rose to 92 percent in 2009 and 109 percent in 2010 compared to 58 percent on average in $2003-08$, as international financial organizations and some bilateral creditors stepped up financing to help the country mitigate the effects of the crisis. At the end of 2011, the main official creditors were the International Monetary Fund (38 percent of the outstanding external public debt), the International Development Association (33 percent), and Paris

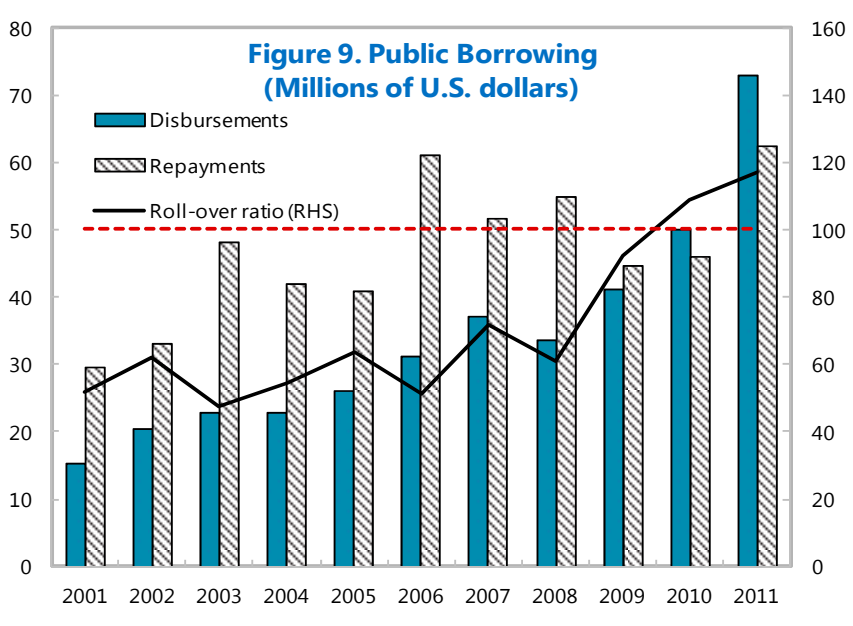

Sources: National Bank of Moldova; and IMF StaffCalculations. Club countries (15 percent). That said, public borrowings have been much smaller than private ones.

\section{Currency Mismatches}

18. A broad-based deterioration in the external environment, e.g., a fall in external demand, is likely to be accompanied by a significant depreciation of the leu, and thus expose economic agents holding short foreign exchange positions to substantial losses. Moldova has in the past limited such exposure by restricting lending in foreign currency, and more recently by regulating such lending, particularly to unhedged borrowers. 
19. The currency position in the banking sector appears comfortable. As of endSeptember 2011 the net foreign exchange position of the banking sector is almost balanced ( 0.9 percent of assets), with domestic lending in foreign currency being financed by a net foreign position of about 6 percent of assets (Table 2). The close-to-balanced forex position in the banking sector as a whole is shared by individual banks.

20. However risks of currency mismatches could still remain in the economy. The size of forex-denominated domestic claims is indeed substantial ( 38 percent of total assets or about 65 percent of exports), hence the burden a large depreciation could place on forex borrowers could a priori be significant if forex borrowing is unhedged - a 10 percent devaluation would raise gross nominal debt on domestic borrowers by almost 4 percent of total assets (roughly 2 percent of GDP). This in turn could lead to non-performing loans (NPLs) and expose the banking sector. Assuming a 10 percent devaluation leads to a 5 percent increase in NPLs, a simple stress test suggests that such a depreciation would require new provisioning equivalent to about 1 percent of total assets and reduce the CAR in banking system by about 3 percentage points.

\section{Conclusion}

21. This paper has examined the main channels through which external shocks spills over into Moldova. Not surprisingly, given the country's very open and still developing economy, we have found that a deterioration in the external environment affects Moldova mainly via a decline in exports and remittances, lowering income and domestic demand, and hence slowing down GDP growth. Financial spillover channels, on the other hand, are not significant in Moldova.

22. Moldova relies heavily on trade and remittances, more or less equally with Europe and CIS countries, with trade concentrated with Russia, Romania, Ukraine, Italy, Germany, and Belarus, and remittances originating mainly from Russia and Italy. Furthermore, exports and remittances are quite sensitive to economic conditions in trading partners. An overall 1 percent decline in foreign income is estimated to cause a decline in exports of equal magnitude and close to a 4 percent decline in remittances. Trade and remittances from the commodity-based CIS economies, especially Russia, allow a diversification of risks, which could for instance dampen the effect of a shock originating in Europe if commodity prices sustain demand in CIS countries. Future work could usefully examine elasticities of trade and remittances with individual countries more closely to better assess the potential effects of a shock.

\section{Moldova's small banking sector is relatively insulated from external}

developments. The potential losses from cuts in foreign assets values or foreign funding for the banking sector as a whole are small relative to total assets and reserves in liquidity, capital, and foreign exchange. A few individual banks, particularly some foreign subsidiaries, are more exposed, reflecting more sizable foreign assets and funding, albeit the 
risk is only moderate. The foreign currency position is almost balanced across banks. However the size of domestic lending in foreign currency suggests that currency mismatches may be significant in the non-banking sector. Thus a large depreciation of the leu could still have significant repercussions on the banking sector if it provokes an increase in NPLs. 


\section{APPENDIX III.I. ECONOMETRIC ANALYSIS OF TRADE AND REMITTANCES FLOWS}

Export equation. The exports in log-first-differences are estimated based on GARCH $(2,2)$ model with real foreign income, relative international export prices, and real effective exchange rate as explanatory variables (Table 1). Two dummies (D_RUS1 (2006Q3-2007Q2) and D_RUS2 (2007Q4-2008Q3) are used to account for the embargo on Moldova's wine exports to Russia in 2006-07.

Table 1. Export Equation

FGDP denotes an index of Moldova's trading partners' real GDP (weighted by their respective 2007-09 export shares and together accounting for at least 95 percent of Moldova's trade);

$R E P$ denotes a relative export price, calculated as $\ln (R E P)=\ln ((E X P D E F)$ $\ln (F G D P D E F)$, where EXPDEF is a component-based trade export deflator from the IMF's database and FGDPDEF the GDP deflator index of Moldova's advanced economies trading partners (weighted by their 2007-2009 share in Moldova's total exports in goods);

$R E E R$ represents the real effective exchange rate.

\begin{tabular}{|c|c|c|c|}
\hline \multirow{3}{*}{$\begin{array}{l}\text { Specification } \\
\text { 2000Q1-2010Q3 }\end{array}$} & \multicolumn{3}{|c|}{ I } \\
\hline & \multicolumn{3}{|c|}{$\operatorname{GARCH}(2,2)$} \\
\hline & Coeff. & $z$-Stat. & \\
\hline \multicolumn{4}{|l|}{ Mean exports } \\
\hline Constant & 0.049 & 1.21 & \\
\hline FGDP & 6.870 & 1.98 & ** \\
\hline$F G D P_{t-1}$ & -5.841 & -1.73 & * \\
\hline$R E P$ & -3.569 & -2.87 & *** \\
\hline$R E P_{t-1}$ & 1.978 & 1.52 & \\
\hline$R E E R$ & 0.443 & 1.11 & \\
\hline$R_{E E R_{t-1}}$ & -0.343 & -0.91 & \\
\hline$D-R U S 1$ & -0.085 & -1.94 & * \\
\hline D-RUS2 & 0.006 & 0.07 & \\
\hline \multicolumn{4}{|l|}{ Variance } \\
\hline Constant & 0.015 & 2.18 & ** \\
\hline$u_{t-1}^{2}$ & -0.116 & -0.82 & \\
\hline$u^{2} t_{-2}$ & -0.189 & -2.10 & *** \\
\hline$\sigma_{t-1}^{2}$ & 0.181 & 0.30 & ** \\
\hline \multicolumn{4}{|l|}{$\sigma_{t_{-}}^{2}$} \\
\hline Summary Statistics & & Prob. & \\
\hline$R$-squared & 0.39 & & \\
\hline F-statistc & 2.45 & 0.03 & \\
\hline Akaike criterion & -1.32 & & \\
\hline Schwarz criterion & -0.91 & & \\
\hline Durbin-Watson & 1.80 & & \\
\hline$A R C H-L M[4]$ & 0.49 & 0.74 & \\
\hline$\angle B O^{2}[1]$ & 0.00 & 0.99 & \\
\hline$\angle B O^{2}[2]$ & -0.08 & 0.85 & \\
\hline$\angle B O^{2}[3]$ & -0.07 & 0.91 & \\
\hline
\end{tabular}

Source: IMF Staff Calculations.

Note: *** indicates significance at the $1,{ }^{*} 5$, and $* 10$ percent level (calculated using the BollerslevWooldridge robust QM standard errors). All coefficients are estimated using the Berndt-Hall-HallHausman algorithm for maximization. 
Import equation. The imports are also estimated in log-first-differences using GARCH $(2,0)$ model with domestic income, relative import prices, and real effective exchange rate as explanatory variables (Table 2).

$G D P$ - a domestic income proxy, equal to the product of real GDP and nominal US\$/Lei exchange rate; $R I P$ - a relative import price index , calculated as $\ln (R I P)=\ln (I M P D E F)-\ln$ $(G D P D E F)+\ln (E X R I)$, where IMPDEF is a component-based trade import deflator index, GDPDEF Moldova's GDP deflator index provided by Moldova's NBS and EXRI a nominal US\$/Lei exchange rate.

Compensation equation. The total compensation, which is equal to the sum of remittances and compensation to employees, in log-first-differences is modeled as a function of foreign income (FGDP), real domestic income (DGDP), nominal effective exchange rate (NEER), and GDP-weighted foreign inflation (FCPI).

As all the variables in the equations are in logs, regression coefficients represent elasticities of dependent variables with respect to explanatory variables. Since lags and contemporaneous values of the explanatory variables are included in the regression equations, the elasticities on dependent variables to these explanatory variables are calculated as a sum of coefficients for the lagged and contemporaneous values.
Table 2. Import Equation

\begin{tabular}{|c|c|c|c|}
\hline \multirow{3}{*}{$\begin{array}{l}\text { Specification } \\
\text { 2000Q1-2010Q3 }\end{array}$} & \multicolumn{3}{|c|}{ I } \\
\hline & \multicolumn{3}{|c|}{$\operatorname{GARCH}(2,0)$} \\
\hline & Coeff. & $z$-Stat. & \\
\hline \multicolumn{4}{|l|}{ Mean imports } \\
\hline Constant & -0.008 & -0.32 & \\
\hline GDP & 1.571 & 6.39 & *** \\
\hline$G D P_{t-1}$ & 0.203 & 0.75 & \\
\hline$R I P$ & -0.477 & -3.11 & $\star \star \star *$ \\
\hline$R I P_{t-1}$ & -0.512 & -2.90 & *** \\
\hline$R E E R$ & 0.647 & 4.11 & *** \\
\hline$R E E R_{t-1}$ & -1.153 & -6.32 & *** \\
\hline \multicolumn{4}{|l|}{ Variance } \\
\hline Constant & 0.006 & 2.85 & *** \\
\hline$u^{2} t_{-1}$ & -0.148 & -2.13 & ** \\
\hline$u_{t-2}^{2}$ & 0.312 & 1.59 & \\
\hline Summary Statistics & & Prob. & \\
\hline$R$-squared & 0.71 & & \\
\hline F-statistc & 9.63 & 0.00 & \\
\hline Akaike criterion & -1.83 & & \\
\hline Schwarz criterion & -1.42 & & \\
\hline Durbin-Watson & 1.58 & & \\
\hline$A R C H-L M[4]$ & 0.30 & 0.87 & \\
\hline$\angle B O^{2}[1]$ & -0.06 & 0.69 & \\
\hline$\angle B O^{2}[21$ & -0.06 & 0.85 & \\
\hline$\angle B O^{2}\lceil 31$ & -0.11 & 0.83 & \\
\hline
\end{tabular}

Source: IMF Staff Calculations.

Note: ${ }^{* *}$ indicates significance at the $1,{ }^{* *} 5$, and ${ }^{*} 10$ percent level (calculated using the BollerslevWooldridge robust QM standard errors). All coefficients are estimated using the Berndt-Hall-HallHausman algorithm for maximization.

Table 3. Compensation Equation

\begin{tabular}{lrrr}
\hline \multicolumn{4}{c}{ Specification } \\
\multicolumn{4}{c}{ 2000Q1-2011Q2 } \\
\cline { 2 - 4 } & Coeff. & t-Stat. \\
\hline Constant & -0.122 & -1.51 & \\
FGDP & 3.895 & $4.00 \quad * *$ \\
DGDP & 1.581 & $2.08 \quad * *$ \\
NEER & -0.579 & $-2.15 \quad * *$ \\
FCPI & 6.045 & 1.15 & \\
Summary Statistics & & Prob. & \\
$\quad$ R-squared & 0.77 & & \\
$\quad$ Adj R-squared & 0.74 & & \\
$\quad$ F-statistc & & 0.00 \\
\hline
\end{tabular}

Source: IMF Staff Calculations.

Note: ** indicates significance at the $1,{ }^{* *} 5$, and ${ }^{*} 10$ percent level. 